Illinois State University

ISU ReD: Research and eData

Theses and Dissertations

3-15-2016

\title{
A Law for Rulers and People: David Davis, Ex Parte Milligan, and Constitutional Liberalism During the Civil War Era
}

John Lewis Moreland

Illinois State University, jmorela@ilstu.edu

Follow this and additional works at: https://ir.library.illinoisstate.edu/etd

Part of the History Commons, and the Law Commons

\section{Recommended Citation}

Moreland, John Lewis, "A Law for Rulers and People: David Davis, Ex Parte Milligan, and Constitutional Liberalism During the Civil War Era" (2016). Theses and Dissertations. 587.

https://ir.library.illinoisstate.edu/etd/587

This Thesis is brought to you for free and open access by ISU ReD: Research and eData. It has been accepted for inclusion in Theses and Dissertations by an authorized administrator of ISU ReD: Research and eData. For more information, please contact ISUReD@ilstu.edu. 
A LAW FOR RULERS AND PEOPLE: DAVID DAVIS, EX PARTE MILLIGAN, AND CONSTITUTIONAL LIBERALISM DURING THE

CIVIL WAR ERA

John L. Moreland

156 Pages

This thesis examines the political and judicial life of Judge David Davis, his opposition to partisan politics, his maturation as a civil libertarian, his drafting of Ex parte Milligan (1866), and the opinion's impact on the partisanship and political instability of Reconstruction.

KEYWORDS: David Davis, Ex parte Milligan, Partisanship, Reconstruction 


\section{A LAW FOR RULERS AND PEOPLE: DAVID DAVIS, EX PARTE MILLIGAN, AND CONSTITUTIONAL LIBERALISM DURING THE \\ CIVIL WAR ERA}

JOHN L. MORELAND

A Thesis Submitted in Partial

Fulfillment of the Requirements for the Degree of

MASTER OF ARTS

Department of History

ILLINOIS STATE UNIVERSITY

2016 
(C) 2016 John L. Moreland 


\section{A LAW FOR RULERS AND PEOPLE: DAVID DAVIS, EX PARTE MILLIGAN, AND CONSTITUTIONAL LIBERALISM DURING THE \\ CIVIL WAR ERA}

JOHN L. MORELAND

COMMITTEE MEMBERS:

Stewart Winger, Chair

Alan Lessoff

Ron Gifford

Daniel Stump 


\section{ACKNOWLEDGMENTS}

The writer wishes to thank Uncle Randy, who is responsible for my obsession with the Civil War. Thank you. Dave, who believed in me and saw a potential no one else did. Erin, for the life-sustaining, home-cooked dinners, the countless hours you listened to me vent, and for simply being a never-ending source of inspiration, motivation and strength. I love you. Dr. Winger, for stretching my intellectual capabilities into realms unknown. You showed me how to ask the right kind of historical questions and reaffirmed my dream of being a teacher. Dr. Lessoff, for being the "nuts-and-bolts" of my thesis. I could not have done it without your guidance. Dr. Stump, for the sanity walks and always being a pillar of optimism. Things do happen for a reason. Dr. Gifford, for teaching me the art of historical prose and helping me write a thesis worth reading. Dr. Marcia Young, for helping me better understand Judge Davis through your invaluable insight. Pat Schley, for helping me locate those Davis letters that became the most critical aspect of my thesis. Lastly, to Grandma Darsham (1933-2014) for whom this thesis is dedicated. You did not always understand what I was doing with my life, but supported me 100 percent nonetheless. I am thankful you got to see me get into graduate school. I miss you.

J. L. M. 


\section{CONTENTS}

Page

ACKNOWLEDGMENTS

CONTENTS

CHAPTER

I. "ONE OF THE BULWARKS OF AMERICAN LIBERTY": THE LEGAL AND HISTORICAL SCHOLARSHIP OF EX PARTE MILLIGAN.

II. DAVID DAVIS: JURIST \& CIVIL LIBERTARIAN 21

III. GUILTY BY ASSOCIATION: THE INDIANAPOLIS TREASON TRIAL AND EX PARTE MILLIGAN

IV. “A LAW FOR RULERS AND PEOPLE”: DAVID DAVIS'S MAJORITY OPINION

V. "THE CONSTITUTIONAL TWADDLE OF MR. JUSTICE DAVIS": EX PARTE MILLIGAN AND RECONSTRUCTION

VI. CONCLUSION 


\section{CHAPTER I}

\section{“ONE OF THE BULWARKS OF AMERICAN LIBERTY" 1: THE LEGAL AND HISTORICAL SCHOLARSHIP OF EX PARTE MILLIGAN.}

On a clear, crisp December morning in 1862, Judge David Davis of the Illinois $8^{\text {th }}$ Judicial Circuit climbed the steps of the U.S. Capitol building to be sworn in as the next Associate Justice of the United States Supreme Court. His three-hundred pound frame carried a large round head, set upon a short neck. His forehead was high, thinly shaded by gray-brown hair. His full broad, double chinned face was clean shaven, down to a rim of light-gray whiskers, which ran around from ear to ear under his jaw. ${ }^{2}$

At twelve o'clock noon, he followed Chief Justice Roger B. Taney and his associates in a procession into the chamber of the Supreme Court. Taney unrolled a parchment announcing that they had received the commission of David Davis, and ordered it read by the clerk. The Chief Justice then asked, "Is Mr. Davis ready to take the oath?" Davis bowed his head, took the parchment, read it, and kissed the Bible. He then

\footnotetext{
${ }^{1}$ Charles Warren, The Supreme Court in United States History, Vol. II (Boston: Little, Brown, and Company, 1935), 427.

${ }^{2}$ Harry E. Pratt, “David Davis” (PhD diss., University of Illinois, 1930), 118. 
adjourned into the corridor where he was robed in fourteen yards of black silk. The Court rose as the U.S. Marshal escorted Davis to his seat on the extreme left of the Chief Justice. The justices all bowed, he bowed in response, then took his seat. ${ }^{3}$ For the next fifteen years David Davis helped interpret and frame the supreme law of the land. Over the course of the American Civil War he had evolved into an eminent jurist, devoted to defending the civil liberties of Northern citizens. After directly intervening on behalf of several Northern Peace Democrats who faced trial by military commission, Davis struck down the use of these tribunals in the landmark case ex parte Milligan.

This thesis will attempt to place the 1866 Supreme Court case ex parte Milligan and its author, David Davis, in the historical context of the American Civil War and Reconstruction. It is a story of vital importance to both legal historians and Civil War-era historians. Davis's letters and papers have been reexamined with particular attention to his political views and his development as a judge and civil libertarian. Radical Republican reaction to Milligan in both newspapers and the Congressional Globe have also been reevaluated to better understand the Radicals' interpretation of Davis's majority opinion. While Radical Republicans viewed ex parte Milligan as both a condemnation of the Lincoln administration's use of military commissions during the Civil War and as an attack on Congressional Reconstruction, ironically Davis did not intend for his ruling to apply to the Reconstruction South where he thought the use of military commissions might remain constitutional. As a common law, circuit court judge, Davis became increasingly concerned with civil liberties issues during the Civil War and directly

\footnotetext{
3 Pratt, "David Davis,"119.
} 
intervened on behalf of Peace Democrats who faced many of these violations. This did not mean he opposed a vigorous pursuit of military reconstruction in the post-war South.

Simultaneously, this study will follow Davis's growing anti-Partyism over the course of his life and career, thus explaining, in part, his opposition to both Radical Republicans and Peace Democrats. This anti-Partyism also explains why he was able to rise above the political fray and stand up for the civil liberties of Peace Democrats and why, in Milligan, he did not go so far as to prohibit Radical-backed military commissions in the South. He consistently maintained a judicial middle-ground. The problem with the existing literature of David Davis, ex parte Milligan, and the judicial politics of Reconstruction, is that historians have failed to place Davis and his majority opinion in the historical framework of civil liberties during the Civil War and Reconstruction. This work intends to fill that scholarly void.

On December 17, 1866, the United States Supreme Court handed down its landmark decision in ex parte Milligan, declaring that the military trial of civilians was unconstitutional when the civilian courts were open and functioning. ${ }^{4}$ Sixty-nine years later, in 1935, legal historian Charles Warren hailed the decision as "one of the bulwarks of American civil liberties" and paid equal homage to its author, Justice David Davis. ${ }^{5}$

Despite being issued a year after the American Civil War, Ex parte Milligan has been often cited in subsequent legal cases in order to check presidential actions during wartime in the interest of protecting civil liberties. It can be said that the decision in $E x$

\footnotetext{
${ }^{4}$ Ex parte Milligan, 71 U.S. 2, 6 (1866).

5 Warren, The Supreme Court in United States History, 427.
} 
parte Milligan was not settled in 1866 and, in recent Supreme Court decisions regarding military commissions, remains unsettled. As legal scholar Curtis Bradley has noted, "The extent to which Milligan restricted military jurisdiction was unclear even at the time of the decision...[a]pplying the decision a century and a half later...in the wake of significant intervening precedent and substantial changes in the nature of the country and of the world, leaves substantial room for judicial discretion." $"$ This judicial discretion, as we will see, has led to broadly different interpretations and applications of Milligan. In addition to legal precedent, there are two other sources for the case's interpretation: constitutional scholarship and legal history.

Since the case was handed down in 1866 , there has been a long and complicated history of attorneys and judges interpreting Milligan where it has been cited in subsequent legal cases relating to presidential war powers, the role of courts during wartime, and even the classification of non-traditional combatants. ${ }^{7}$ Shadowing this battle in the courts, legal scholars and historians continued to write about Milligan from widely diverging points of view and for a variety of reasons. It is therefore vital to understand the difference between legal scholarship and historical scholarship and how they intersect within legal history. Legal scholars associated with law schools, such as Dan Farber and Paul Finkelman tend to focus on constitutional law and theory. They see law as fundamentally different from politics. As legal historian Michael Les Benedict

${ }^{6}$ Curtis A. Bradley, "The Story of Ex parte Milligan: Military Trials, Enemy Combatants, and Congressional Authorization" in Presidential Power Stories, eds. Christopher H. Schroeder and Curtis A. Bradley (St. Paul: Foundation Press, 2009), 130.

${ }^{7}$ See Ex parte Quirin, 317 U.S. 1 (1945), Duncan v. Kahanamoku, 327 U.S. 304 (1946), Hamdi v. Rumsfield, 542 U.S. 507 (2004), Rasul v. Bush, 542 U.S. 466 (2004), Padilla v. Hanft, 423 F.3d 386 (4 ${ }^{\text {th }}$ Cir. 2005), Hamdan v. Rumsfeld, 548 U.S. 557 (2006), and Boumediene v. Bush, 553 U.S. 723 (2008). 
aptly explains, "[P]olitics is about the exercise of power, while law is about the application of rules." ${ }^{8}$ From this particular perspective, after the political process has established a constitutional provision, its legal interpretation is left to the judiciary. Therefore, in the context of the Constitution, legal scholars have determined the "original intent" of the framers and how judges today should interpret constitutional law in a $21^{\text {st }}$ century society. ${ }^{9}$ This dichotomy between politics and law will be extremely important to remember when we explore Davis's own views on how politics and law interacted with one another. Davis himself strove to rise above the political fray when considering the application and interpretation of law. Whether he was successful in doing so, will be explored in the coming chapters.

Legal historians, conversely, do not study legal history for legal purposes, but to understand why things happened the way they did and how they have affected the subsequent course of events. Possessing a wider vision of constitutional politics, legal historians see the framing and consequences of Civil War and Reconstruction era law as part of a much longer and broader political process in which judges played a smaller role. Thus, constitutional law is one piece in the larger puzzle of our constitutional system. As Benedict again notes, "Even the histories of the Reconstruction era that attend the most closely to constitutional issues do not try to tease out exact understandings and intentions

\footnotetext{
${ }^{8}$ Michael Les Benedict, Preserving the Constitution: Essays on Politics and the Constitution in the Reconstruction Era (New York: Fordham University Press, 2006), ix.

${ }^{9}$ Benedict, Preserving the Constitution, ix-x.
} 
[of the framers]." ${ }^{10}$ In other words, judges were creating new law rather than interpreting old law.

As noted earlier, after Milligan was handed down in 1866, the case lay dormant for an extended period of time. In the years after Reconstruction, few legal situations arose in which military commissions were deemed necessary; however, in the waning years of the $19^{\text {th }}$ century, historians and political scientists began to examine the Civil War within the halls of the academy. Twenty-two years after Milligan, historian William A. Dunning, John Burgess, and Sydney Fisher gave their analysis of the case. In 1887, Dunning, who greatly influenced later generations of Reconstruction scholars, noted how the use of military commissions remained unchecked by the Supreme Court throughout the war. Dunning saw this as the Court being intimated by the Radicals. Milligan, he concluded, provided an opportunity for the Court to reassert its judicial authority. He labeled the Milligan case, therefore, an act of "judicial hostility to Congress." 11 This thesis views Dunning's assertion that the Court had been intimidated by the Radicals and hostile towards Congress as somewhat exaggerated. While Davis did make an obiter dicta statement against Congressional power to establish military commissions, as an obiter dicta statement, it was not binding. Obviously he was hostile toward Congress, yet this did not mean that Davis opposed the use of military commissions in the South.

\footnotetext{
${ }^{10}$ Ibid., $\mathrm{x}$.

${ }^{11}$ William A. Dunning, "The Constitution of the United States in Reconstruction," Political Science Quarterly 2 (December 1887): 558-602, quoted in Peter J. Barry, "Ex parte Milligan: History and Historians," Indiana Magazine of History 4 (December 2013), 362.
} 
Indeed, Davis left the authority of military commissions in the South

unchallenged. In defense of arbitrary power during war, political essayist Sydney Fisher stated in 1888 that:

It is generally admitted that when a government is attacked by a rebellion it is impossible for it to protect itself from conspirators and assassins if every one of them has to be taken before a court of law and proved guilty beyond a reasonable doubt. In such a crisis some arbitrary power must be given.

Fisher saw Milligan playing "havoc with the theories that prevailed during the war."12 Burgess also wrote a pessimistic assessment of Milligan's long-term authority. In 1891 he wrote, "It is devoutly to be hoped that the decision of the court may never be subject to the strain of actual war. If, however, it should be, we may safely predict that it will be necessarily disregarded."13 These comments have proven prophetic. Instead of focusing on Milligan's impact on Reconstruction, however, Fisher and Burgess established a conversation about Milligan's impact on America's legal apparatus involving civilians and military relations during wartime. That conversation would remain unchanged for generations to come. This study will attempt to shift that conversation away from a legal and political theory context and toward an historical context in which David Davis, Milligan, and the Civil War era are studied as a whole.

\footnotetext{
12 Sydney G. Fisher, "The Suspension of Habeas Corpus During the War of the Rebellion," Political Science Quarterly 3 (September 1888): 478, quoted in Barry, "Ex parte Milligan,” 363.

13 John W. Burgess, Political Science and Comparative Constitutional Law (Boston: Ginn \& Company, 1891): 251, quoted in Barry, "Ex parte Milligan," 362.
} 
Understandably, early $20^{\text {th }}$ century historians continued the discussion of Milligan during World War I. However, an historical analysis of the case, specifically in regards to how it affected Reconstruction and David Davis's role, was still absent from the scholarly conversation. The discussion still centered on a strictly legal viewpoint. Several legal scholars responded to Congress when it amended the Articles of War to guarantee the authority of military commissions during World War I. University of Minnesota Law Professor Henry J. Fletcher commented on the Milligan case in 1917 stating, "Public danger warrants the substitution of executive process for judicial process." ${ }^{14}$ Conversely, in his 1920 book, Freedom of Speech, Harvard Law Professor and civil libertarian Zechariah Chafee Jr. firmly believed that the Bill of Rights should hold under both war and peace and cited Milligan as a part of this fundamental principle. "A majority of the Supreme Court declared the war power of Congress to be restricted by the Bill of Rights in ex parte Milligan, which cannot be lightly brushed aside."15 This is the same reasoning that Davis took in his majority opinion. Perhaps the most influential and comprehensive work on the legal history of the Civil War and Reconstruction is J.G. Randall's 1926 book Constitutional Problems under Lincoln. In regards to the split between Davis's majority opinion in Milligan which declared Congress did not have power to authorize military commissions outside a war zone and Chief Justice Salmon P. Chase's concurring opinion which would have upheld Congressional but not executive power to establish home-front military commissions. Randall observed that this left "the

\footnotetext{
${ }^{14}$ Henry J. Fletcher, “The Civilian and the War Power," Minnesota Law Review 2 (1917): 130, quoted in Barry, "Ex parte Milligan," 364.

${ }^{15}$ Zechariah Chafee Jr., Freedom of Speech (New York: Harcourt, Brace and Howe, 1920): 33, quoted in Barry: "Ex parte Milligan," 364.
} 
impression of a court about to swing from one opinion to another." ${ }^{16}$ As we will see, this split, in fact, was the hinge upon which Milligan decidedly affected Reconstruction. If one accepts the premise that Chase was representative of Radical Republicans, Davis provides an opposing view to Congressional Radicals and their constitutional authority during Reconstruction. Yet, as we will see, Davis's and Chase's opinions were not all that different. The "split" as Randall observed, came down to a misinterpretation of where Davis objected to the use of military commissions.

In 1929, legal scholar Samuel Klaus published a seminal piece The Milligan Case, which included the proceedings of the military commission that tried Milligan and the briefs submitted to the United States Supreme Court. Klaus minimized the significance of the case by citing a 60 year span of time marked by no situation that dictated the suspension of habeas corpus or the trial of civilians by military commissions. Klaus asserted, "It is precisely for this rare and crucial situation that Ex Parte Milligan purports to assert a rule of judicial decision." ${ }^{\prime 17}$ This thesis, however, will argue that the significance of Milligan does not reside in its standing as legal precedent as Klaus and his predecessors have contended. Milligan's significance resides more generally as a part of the evolution of civil liberties thinking in the North coming out of the Civil War and is thus of enormous historical significance, despite its legal obscurity.

\footnotetext{
${ }^{16}$ James G. Randall, Constitutional Problems under Lincoln (New York: D. Appleton and Company, 1926): 176, quoted in Barry: "Ex parte Milligan," 365.

${ }^{17}$ Samuel Klaus, ed., The Milligan Case (New York: Knopf, 1929): 62, quoted in Barry, "Ex parte Milligan,” 366.
} 
Ironically, that "rare and crucial situation," as Klaus put it, came quickly with the advent of World War II. Attorney and civil libertarian John P. Frank took a favorable position on Milligan in 1944. In "Ex Parte Milligan v. The Five Companies: Martial Law in Hawaii," Frank, repeated Charles Fairman, in stating that the Milligan opinion was a "bulwark for the protection of the civil liberties of every American citizen." ${ }^{18} \mathrm{He}$ concluded that the U.S. Constitution applied in Hawaii and, therefore, the military trials of civilians on the island were illegal. Once again, finding answers to military authority during wartime precluded any historical scholarship on Milligan, David Davis, and the Civil War era. Failing to contextualize Milligan properly during the Civil War and Reconstruction left out an entirely new and significant perspective on how law and politics interacted.

The Cold War again provided a period in which the question of military trials of civilians was temporarily put to rest. Because there were no active hostilities during this period, military commissions were not called upon to try civilians. However, 1960s liberalism placed Milligan back onto the examination table. Although not a figure of the 1960s, but rather a mid-century intellectual, Allan Nevins saw Lambdin P. Milligan as simply a "loose cannon" in an era of sectionalism and did not deserve historical attention. Nevins's characterization of Lambdin P. Milligan as unimportant has largely been discredited by today's expanding historical scholarship on Peace Democrats and the Northern war resistance. Much of this will be explored in chapter 2. According to

\footnotetext{
${ }^{18}$ John P. Frank, "Ex Parte Milligan v. The Five Companies: Martial Law in Hawaii," Columbia Law Review 44 (September 1944): 639, quoted in Barry, "Ex parte Milligan,” 368.
} 
Nevins though, the political situation that created the case was more important. He explained, "Although Lincoln was the last man in the world to make himself such a despot, he might conceivably have a successor someday who, unless a clear line were drawn, would permit the erection of a martial autocracy. The line was now emphatically delineated." 19 In other words, Milligan created a legal barricade for any future president who might want to expand military rule even further than what it had been during the Civil War.

In his 1968 book, Judicial Power and Reconstruction Politics, revisionist historian Stanley Kutler challenged Dunning's opinion that the Court had been intimidated by the Radical Republicans. Rather, the Court conducted itself with "forcefulness and not timidity, by judicious self-imposed restraint rather than retreat, by boldness and defiance instead of cowardice and impotence." ${ }^{20}$ Milligan, therefore, was a reflection of the Court's attempt to reassert its constitutional authority and to preserve civil liberties in the framework of American government by striking down expanded executive and legislative power. Like his predecessors, however, Kutler left the story of Milligan's impact on Reconstruction untold. This thesis comes closest to finishing Kutler's story: the Court did show “judicious self-imposed restraint.” Davis's majority opinion in Milligan did preserve civil liberties in America by striking down military commissions. I contend, however, that by intent Milligan only applied to the North.

${ }^{19}$ Allan Nevins, "The Case of the Copperhead Conspirator," in Quarrels That Have Shaped the Constitution, ed. John A Garraty (New York: Harper, 1964): 108, quoted in Barry, "Ex parte Milligan," 370 .

${ }^{20}$ Stanley Kutler, Judicial Power and Reconstruction Politics (Chicago: University of Chicago Press, 1968): 92, quoted in Barry, "Ex parte Milligan,” 370. 
Considering his opposition to Radical Republicans, Davis showed great self-restraint when he allowed Radical-backed military commissions in the South to remain in place.

In 1970, archivist Joseph P. Gambone confirmed Kutler's impression of Milligan's importance for judicial supremacy and civil liberties. He concluded, "By virtue of the Milligan decision, the Supreme Court restored itself to a position of greater prestige, and reaffirmed its position as the "final arbiter of the Constitution""21 This was a part of a larger process that was rapidly resulting in the rise of judicial supremacy in the late nineteenth century. Charles Fairman revisited the Milligan case in 1971 whereby he largely reiterated his analysis in 1942. However, he qualified his earlier findings by stating that "the very words of the Milligan opinion should not be taken as precise test for all future emergencies." 22 In other words, judges may, over time, contemplate different applications of Milligan to new military or national security situations. For legal scholars then, this is the heart of evolving legal interpretation. Yet, the historical significance of Milligan and its author in the context of the Civil War and Reconstruction has yet to be explored.

Another decade would pass before a historian would again take up the question of Milligan's historical significance. In regards to the author of Milligan, historian Harold Hyman declared in 1982 declared that "Justice Davis paid the Bill of Rights such respects as had not sounded in the chamber since Taney's tribute to the Fifth Amendment in Dred

\footnotetext{
${ }^{21}$ Joseph G. Gambone, "Ex Parte Milligan: The Restoration of Judicial Prestige?" Civil War History 16 (September, 1970): 259, quoted in Barry, "Ex parte Milligan," 371.

${ }^{22}$ Charles Fairman, History of the Supreme Court of the United States (New York: The Macmillan Co., 1971), 233.
} 
Scott." ${ }^{23}$ Hyman's statement was deeply ironic given that Taney declared the Due Process Clause of the Fifth Amendment prohibited the federal government from freeing slaves brought into federal territory. ${ }^{24}$ The only other Bill of Rights case that came before the Supreme Court, prior to the Civil War, was Barron v. Baltimore (1833). In this case, the Court declared that the Bill of Rights could not be applied to state governments. ${ }^{25}$ Nonetheless, Davis in his majority opinion would use the Due Process Clause (in part) to strike down the use of military commissions in the North. Starting with Nevins, historical analysis of Milligan finally started to take hold. Yet, the analysis was focused on the case's place in antebellum legal history and its impact on the Supreme Court's authority. This was very useful but scholars still had not addressed the case's impact on the civil liberties issues coming out of the Civil War, Davis's role, or the way the Reconstruction political context might provide a key to its meaning.

Legal historian, Mark Neely Jr., explored the "irrelevancy" of the decision in his 1991 treatise, The Fate of Liberty: Abraham Lincoln and Civil Liberties. He concluded that the 1866 case was inapplicable during wartime, since it was decided during peacetime. Therefore, "the real legacy of Ex Parte Milligan is confined between the covers of constitutional history books. The decision itself had little effect on history." ${ }^{26}$ This thesis directly challenges Neely's assertion. As the story unfolds in the proceeding chapters, David Davis and Milligan had a significant impact on Reconstruction, not in the

${ }^{23}$ Harold Hyman and William M. Weicek, Equal Justice Under the Law: Constitutional Development, 1835-1875 (New York: Harper \& Row, 1982), 382.

${ }^{24}$ Dred Scott v. John F. A. Sandford, 60 U.S. 393 (1857).

${ }^{25}$ Barron v. Baltimore, 32 U.S. (7 Pet.) 243 (1833).

${ }^{26}$ Mark Neely, Jr., The Fate of Liberty: Abraham Lincoln and Civil Liberties (New York: Oxford University Press, 1991): 184, quoted in Barry, "Ex parte Milligan,” 374. 
opinion itself but rather in the way Radical Republicans viewed the opinion as an attack on Congressional Reconstruction.

Five years later, in 1996, Supreme Court Chief Justice William Rehnquist's All the Laws but One provided a unique perspective on Milligan. He concluded that:

The Milligan decision is justly celebrated for its rejection of the government's position that the Bill of Rights has no application in wartime. It would have been a sounder decision, and much more widely approved at the time, had it not gone out of its way to declare that Congress had no authority to do that which it never tried to do. ${ }^{27}$

Justice Rehnquist's evaluation of Davis's majority opinion in which he declared Congress did not have the authority to establish military commissions is particularly germane to this thesis. As we will see, Davis's statement on Congressional power triggered Radical understanding of Milligan as an attack on Congressional Reconstruction. It is therefore understandable why Congress launched several attacks on the Supreme Court soon thereafter, such as reducing its membership and restricting its appellate jurisdiction.

The post-9/11 world provided another opportunity to shed new light on Milligan. In a 2003 article for The Nation, Eric Foner commented on the threats to civil liberties during wartime:

In the aftermath of the Civil War, a far greater crisis than the war on Iraq, the Supreme Court in the Milligan case invalidated the use of military tribunals to try civilians.

${ }^{27}$ William H. Rehnquist, All the Laws but One: Civil Liberties in Wartime (New York: Vintage, 1998): 137, quoted in Barry, "Ex parte Milligan," 375. 
The Court proclaimed that the Constitution is not suspended in wartime...Alas we have not always lived up to this ideal. The history of civil liberties in the United States is not always a straight-line trajectory toward ever greater freedom. It is a complex story in which victories can prove temporary and regression can follow progress. ${ }^{28}$

Foner gave a full-throated endorsement to the heroic liberal view of the Davis opinion even while admitting that the decision had often been honored only in the breech. Remarkably, our foremost historian of Reconstruction did little to contextualize the Davis opinion in the field of his own expertise.

Constitutional scholars John Yoo and Curtis Bradley addressed Milligan in the context of post-9/11 military detentions and tribunals. Yoo was a Deputy Assistant U.S. Attorney General during the Bush Administration and the author of the "Torture Memo" which greatly expanded executive authority in the context of enhanced interrogation techniques. In 2008, Yoo declared that "Milligan was not just a vindication of Merryman, but a dramatic expansion of it." ${ }^{29}$ Milligan elicited a broader question: does the suspension of habeas corpus allow for the military trial of civilians? Yoo's analysis is somewhat shortsighted. Merryman, in effect, established nothing because Lincoln ignored it. Additionally, Davis did not strike down Lincoln's executive suspension of habeas corpus. Yoo went on to criticize Milligan by defending the use of military commissions and opposing the Supreme Court's role in reviewing executive authority

\footnotetext{
${ }^{28}$ Eric Foner, "Dare Call It Treason," The Nation, June 2, 2003 quoted in Barry, "Ex parte Milligan," 376.

${ }^{29}$ John Yoo, "Merryman and Milligan," Journal of Supreme Court History 34 (November 2008), 519.
} 
during wartime. For Yoo, allowing the Court to review military commission proceedings "ignores the costs of judicial intervention...to the war effort." 30

In 2009, Curtis Bradley concluded that "[p]erhaps the greatest significance of Milligan is symbolic rather than doctrinal. [It] provides a precedential counterweight to claims of unlimited government authority in wartime."”11 A national crisis, again, advanced the question of military authority over civilians, leaving historical analysis on the back-burner. Yoo and Bradley briefly examined the case's historical relevance and impact on Civil War era civil liberties, but left the question of Reconstruction and the reasoning behind Justice Davis' majority opinion, wholly unanswered.

Despite the attention lavished on ex parte Milligan, the literature on David Davis nevertheless remains quite scarce. The earliest known biography is a 1930 unpublished PhD dissertation by Harry E. Pratt from the University of Illinois. Pratt was the first to use Davis's personal papers in writing this first-ever biography of the judge. This dissertation was simply a blow-by-blow account of Davis's life with no discernable thesis or argument. Likewise, its treatment of Milligan was simply matter-of-fact and adduced that it was Davis's "best work." ${ }^{32}$ There is no mention of how Davis and his opinion impacted civil liberties issues during the Civil War-era.

Not until 1960 did another biography of Davis appear in the historical literature. Chicago attorney Willard King's Lincoln's Manager: David Davis was much more

\footnotetext{
${ }^{30}$ Yoo, "Merryman and Milligan," 533.

${ }^{31}$ Bradley, "The Story of Ex parte Milligan," 376.

${ }^{32}$ Pratt, "David Davis," 137.
} 
expansive than Pratt's. It included then-recently discovered Davis family letters which allowed him to develop a more detailed story of the judge's life. However, much like Pratt's work, King's biography was merely a narrative. "David Davis's chief contribution to American history was the part he played in the nomination of Abraham Lincoln...Had Judge Davis not lived, Lincoln would not have been nominated." ${ }^{33}$ In other words, King did not bring to the forefront Davis's role in civil liberties during the Civil War. Rather he simply focused on a brief moment in a larger, more significant career as a Supreme Court justice. King's analysis of Milligan's significance fell short as well. He simply quoted Charles Warren in calling the opinion "one of the bulwarks of American liberty" and claimed that "it stands in all the grandeur of its original utterance." ${ }^{34}$ By 1960, no historian had yet outlined the historical significance of David Davis in the context of ex parte Milligan and the Civil War and Reconstruction.

In 2009, Connecticut attorney William D. Bader and former Chief Justice Frank J. Williams of the Rhode Island Supreme Court, wrote a biography of Davis in the Roger Williams University Law Review, entitled, "David Davis: Lawyer, Judge, and Politician in the Age of Lincoln." Once again, this work was long on narrative and short on legal/historical argument. Bader and Williams' view of Davis's significance was, "Besides his authorship of Ex Parte Milligan...He pioneered a movement toward implementing an intermediate court of appeals in the federal court system... and his actions as a United States Senator helped shape the structure of today's federal

\footnotetext{
${ }^{33}$ Willard King, Lincoln's Manager (Cambridge: Harvard University Press, 1960), 312.

${ }^{34}$ King, Lincoln's Manager, 258.
} 
judiciary." ${ }^{35}$ It stands to reason that two members of the legal community would form their study of Davis around his impact on the current day judicial system rather than his impact on history. But their view of Milligan's significance simply rested in its use as a legal precedent and not in its significance for Civil War era history.

The judicial politics of Reconstruction are vital to understanding the environment in which the case was understood by public opinion, specifically Radical Republicans. The most recent scholarship on judicial politics during Reconstruction is Pamela Brandwein's Rethinking the Judicial Settlement of Reconstruction. Brandwein challenges the popularly held notion that during Reconstruction and the Gilded Age, the Supreme Court assisted in restoring white supremacy in the South by narrowly interpreting the Thirteenth, Fourteenth, and Fifteenth Amendments. She argues that scholars have overlooked the ways in which the Waite court (1874-1888) allowed for the federal protection of African Americans in the South, protections that successive Congresses and presidencies failed to afford them. She notes that while members of the Waite court such as Joseph Bradley and Samuel Miller ruled that the Thirteenth and Fourteenth Amendments did not guarantee equal access to public accommodations, they did not intend to leave African Americans in the hands of southern white supremacy. Instead, she shows how the Court drew a legal distinction between social, political, and civil rights. The Court held that the Thirteenth, Fourteenth, and Fifteenth Amendments did not provide for equal access to public spaces, but they did allow for federal protection in

${ }^{35}$ William D. Bader and Frank J. Williams, "David Davis: Lawyer, Judge, and Politician in the Age of Lincoln," Roger Williams University Law Review 14 Roger Williams U.L Rev. 163 (Spring 2000): 18. 
national elections if black voters were being subjected to intimidation, violence, or fraud. Additionally, the Court maintained that the federal government could intervene locally if states purposefully failed to protect African Americans' due process rights or property rights. It is true that the Fuller court (1888-1910) finally sanctioned Jim Crow, but they had to first overturn these important Waite court decisions. ${ }^{36}$

This thesis joins Brandwein in arguing that the blame for the failure of Reconstruction should not be laid on the Supreme Court the way it has been. I, however, push this interpretation of the Reconstruction courts back to David Davis's 1866 majority opinion in Milligan. While Davis struck down military commissions in the North, he left executive authority intact in the South, where it could be used to protect freedmen from all-white courts and juries. As we will see in chapter 5, in more than one case, Davis sided with the majority to uphold military commissions in the South.

In sum, legal scholars have examined Milligan in order to understand the role of presidential war power, the role of courts during wartime, and the classification of nontraditional combatants. Historians have done much the same, just within an historical context and less from a legal standpoint. Still, the controlling unanswered questions that lie at the heart of all this historiography, is what is the historical importance of David Davis and Ex parte Milligan in the context of civil liberties issues during the Civil War and Reconstruction; and what is the place of Milligan in the rise of Judicial Supremacy based on the Bill of Rights? I intend to fill this scholarly void by examining how David

${ }^{36}$ See Pamela Brandwein, Rethinking the Judicial Settlement of Reconstruction (New York: Cambridge University Press, 2011). 
Davis emerged as a civil libertarian during the American Civil War, how his constitutional and anti-Partysim views helped shape Ex parte Milligan, and why Radical Republicans misinterpreted this opinion as an attack on Congressional Reconstruction in the South. This chapter in American history has not been told in large part because Abraham Lincoln has overshadowed Davis. Yet, this thesis will rely heavily on Lincoln's correspondence with Davis in order to understand the man and the jurist and to finally give him his long overdue recognition. 


\section{CHAPTER II}

\section{DAVID DAVIS: JURIST AND CIVIL LIBERTARIAN}

During a war replete with civil liberties issues, the military trial of Lamdin P. Milligan and his co-conspirators in the fall of 1864 was a particularly prominent civil liberties case. Many of these civil liberties issues were raised by Peace Democrats, also known as Copperheads who strongly opposed the Northern war effort. Interestingly, Judge David Davis intervened on behalf of many of these Copperheads who had been arrested and tried before military commissions for voicing their discontent with the Lincoln administration. A fundamental understanding of David Davis's anti-Partyism and his maturation as a civil libertarian during the Civil War is therefore necessary to fully appreciate the legal landscape that brought Milligan to trial in the winter of 1864 . Thus we can begin to understand the political environment in which Davis decided the Milligan case and how it was understandably misinterpreted by Radical Republicans.

David Davis was born on the slave-holding Rounds Plantation in Cecil County, Maryland in 1815 . He was nursed by a slave woman and grew up playing with the African-American children on the plantation. At age five, when Davis's grandfather

died, he inherited two slave boys who were sold the next year by his legal guardian. This Southern environment produced in Davis a fervent hatred of Abolitionism. 
Many, particularly in Eastern Maryland, hated abolitionists. ${ }^{37}$ In 1820 , Davis was sent to live with his paternal uncle, Reverend Henry Lyon Davis, in Annapolis. The Reverend was a staunch supporter of Henry Clay and instilled his pro-Clay, moderately anti-slavery beliefs in his nephew at an early age. Through his uncle's influence, Davis himself became a follower of Clay and later a member of the Whig Party. ${ }^{38}$ This political affiliation fostered his adherence to the rule of law and a high view of judicial authority which became one of the foundational blocks of his majority opinion in Milligan.

In 1832, Davis graduated from Kenyon College and then proceeded to study law under Henry Bishop in Lennox, Massachusetts. During this time, he became close to his future father-in-law, Judge William Perrin Walker. Judge Walker's opposition to both slavery and abolitionism reinforced Davis's own views on human bondage as well as on extremist politics. Davis went on to attend Yale Law School graduating in 1835, after which he moved to Pekin, Illinois to begin the practice of law. One year later, he moved his law practice to Bloomington after buying an office from local attorney Jesse Fell. It was during this time in Bloomington that his passion for politics began to grow. As an outspoken Whig, Davis campaigned for William Henry Harrison and protested the annexation of Texas. ${ }^{39}$ In 1844 , Davis was elected to the Illinois legislature where he served as a leading Whig until $1847 .{ }^{40}$

\footnotetext{
${ }^{37}$ Bader and Williams, "David Davis", 2.

${ }^{38}$ Ibid., 2-3.

${ }^{39}$ King, Lincoln's Manger, 36.

${ }^{40}$ Ibid., 3-5.
} 
In the early 1830s, the Whig Party was formed in response to a perceived usurpation of executive power by Andrew Jackson. From this position, they promoted congressional authority over the executive, a high view of the courts and the constitution, and a close adherence to the rule of law. Moreover, they believed in the elastic clause and judicial construction. ${ }^{41}$ This Whiggish background may explain, in part, Davis's decision in Milligan. While both Lincoln and Davis came out of the Whig tradition, Davis upheld the law at all costs. Lincoln, however, seemed to assume there could be no law without order first. In defense of suspending habeas corpus during the Civil War, Lincoln famously asked, were "all the laws, but one, to go unexecuted, and the government itself go to pieces, lest that one be violated?"42 And in his speech on the Dred Scott decision in 1857, Lincoln willingly acknowledged that even the Supreme Court decisions were rooted in public opinion, opinion that could be shaped. ${ }^{43}$ Thus Lincoln viewed constitutional law in more plastic, political, and republican terms.

In April 1844, when the Democratic Convention convened, Martin Van Buren was passed over for James Polk as the nominee. The Whig nominee, Henry Clay, made a politically fatal mistake by opposing the annexation of Texas. In response, the Liberty Party, backed by the political abolitionists, took enough Whig votes from Clay to defeat

${ }^{41}$ Michael Holt, The Rise and Fall of the American Whig Party: Jacksonian Politics and the Onset of the Civil War (New York: Oxford University Press, 1999), 24-30.

42 Abraham Lincoln, "Address before Special Session of Congress" (July 4, 1861), quoted in Mark Neely, Jr., Lincoln and the Triumph of the Nation: Constitutional Conflict in the American Civil War (Chapel Hill: University of North Carolina Press, 2011), 64.

43 Abraham Lincoln, "Speech on the Dred Scott Decision," Springfield, IL (June 26, 1857" quoted in Maureen Harrison, ed. Abraham Lincoln: Word for Word (San Diego: Excellent Books, 1994), 173. 
him, resulting in Polk's election, or at least this was how Lincoln and Davis saw it. After seeing his political hero defeated and never having another chance at winning the presidency due to his age, Davis remarked to his father-in-law, "The abolitionists are hereafter and forevermore shut out of the pale of my sympathy." 44 While Lincoln later worked closely with Owen Lovejoy and Charles Sumner on emancipation, this lack of sympathy for abolitionists and their extremist politics on Davis's part would continue well into the Civil War and thus have a significant impact on Davis's opposition to Radical Republicans. ${ }^{45}$

Likewise, Davis equally despised extremist Democrats known as Locofocos. In 1840, anti-Tammany Democrats were given this name by Whigs when an incident in which leaders of the Democratic Tammany Society in New York attempted to disrupt a meeting of the Young Mechanics in the Society by turning off the gas lights. In response, the men held their meeting by the light of matches called "locofocos." Locofocos supported Andrew Jackson and Martin Van Buren and advocated free trade, greater circulation of specie, and opposed state banks, all of which flew in the face of Whiggish ideology. ${ }^{46}$ In a letter to Julius Rockwell, Davis said, "if some of our Lenox [Masschusetts] friends were to witness the genuine effects of Loco focoism in Illinois, they would not plume themselves greatly upon their adherence to the fortunes of Mr. Van

\footnotetext{
${ }^{44}$ David Davis to William Perrin Walker, February 1845, David \& Sarah Davis Family Correspondence, David Davis Mansion Historic Site, Bloomington, Illinois.

${ }^{45}$ See William F. Moore and Jane Anne Moore, Collaborators for Emancipation: Abraham Lincoln and Owen Lovejoy (Urbana: University of Illinois Press, 2014) and Ronald C. White Jr., A. Lincoln: A Biography (New York: Random House, 2009), 458-459.

${ }^{46}$ Arthur M. Schlesinger, Jr. The Age of Jackson (Boston: Little, Brown and Company, 1953), 190-200.
} 
Buren." ${ }^{47}$ Davis again wrote Rockwell the following year complaining about the decline of the Whig party in Illinois. "The printing of $\mathrm{P}$ [ost] $\mathrm{O}$ [ffice] $\mathrm{D}$ [epartment] is given to the vilest Loco Foco print in the State. Mr. [Daniel] Webster has taken the printing from all the Whig papers in the West \& bestowed it upon the filthiest of the papers opposed to us."48 Davis also placed blame upon the radical Democrats for the Mexican War. "This Mexican War must certainly open the eyes of the American people to the iniquities of Loco Focoism. This Mexican War is playing hob with all business men. Don't you think the Loco Foco party will ruin the Country?"49 It is unclear as to whether Davis thought that Loco focos were directly responsible for the bank and free trade issues thought to have been caused by the war, or simply that the army was taking business men as recruits. Either way, it is clear that he despised the extremist wing of the Democratic Party.

In the spring of 1847 , Davis was elected to the Constitutional Convention which met that June. The president of the convention assigned Davis only to the committee on Law Reform. In this capacity, he helped set up separate supreme and circuit court judges to be elected by the people instead of by the legislature. This was an attempt to insulate judges from direct political manipulation. It came on the heels of a court packing scheme whereby the Democrats in the General Assembly increased the size of the court and put

\footnotetext{
${ }^{47}$ David Davis to Julius Rockwell, February 10, 1841, David \& Sarah Davis Family Correspondence, David Davis Mansion Historic Site, Bloomington, Illinois.

${ }^{48}$ David Davis to Julius Rockwell, April 6, 1841, David \& Sarah Davis Family Correspondence, David Davis Mansion Historic Site, Bloomington, Illinois.

${ }^{49}$ David Davis to Wells Colton, January 4, 1847, David \& Sarah Davis Family Correspondence, David Davis Mansion Historic Site, Bloomington, Illinois.
} 
Stephen A. Douglas on it in order to reverse a court ruling. ${ }^{50}$ So in the context of this thesis, fixing the size of the Court by constitution rather than by simple law might have been a move in the direction of something akin to what we later came to call judicial supremacy.

As in the Illinois General Assembly, the question of African American immigration into the state was the product of much heated debate at the Constitutional Convention. Davis actively fought the prohibition of black immigration as it would offend the northern portion of Illinois. Here we can see early signs of Davis's views on civil liberties and the constitution; perhaps views that would later influence his opinion in Milligan. Even though Davis held prejudicial views himself and in fact personally opposed black immigration into Illinois, he placed his own views aside. In his mind, he had been sent to the constitutional convention to remedy certain problems in the state government and was not willing to endanger the constitution's adoption by this or any other provision. ${ }^{51}$ He would take the same non-partisan stance in Milligan by defending the civil liberties of extremist Democrats and at the same time maintaining Radicalbacked military commissions in the South.

After leaving the legislature, Davis was nominated as a Whig candidate for judge in the newly organized Illinois Eighth Judicial Circuit and was elected without opposition

${ }^{50}$ Howard Schweber, The Creation of American Common Law, 1850-1880 (Cambridge: Cambridge University Press, 2004), 51 and Jerome B. Meites, "The 1847 Illinois Constitutional Convention and Persons of Color," Journal of the Illinois State Historical Society 108, no. 3 (Fall 2015): 277.

${ }^{51}$ Arthur C. Cole, The Constitutional Debates of 1847 (Springfield: Illinois State Historical Library, 1919), 218-219. 
in September of 1848. He served in this position until his appointment to the United States Supreme Court in 1862. As slavery became an increasingly volatile issue in the 1850s and as some Whigs began to abolitionize, Judge Davis feared for his party's future. In a letter to his cousin, Julius Rockwell, Davis wrote his assessment of the KansasNebraska Bill. "Sumner talks unnecessarily saucy. The Southern Senators are not so much to blame as these scoundrels at the North. I regret the movement on this question of slavery, being really afraid that a sectional issue will be made disastrous to this country. Try to save the Whig party. I don't fancy its being abolitionized."52 Like many northern Whigs during this schism in the wake of the Kansas-Nebraska Act of 1854, Davis immediately joined the Republican Party; as opposed to other Whigs who went to the Know-Nothing Party and then to the Republican Party (Mary Lincoln) or those who went to the Know-Nothing Party and then to the Democrats (John Todd Stuart). ${ }^{53}$ Like Lincoln, Davis took the more direct route from Whig to Republican. In a letter to his brother-in-law, Julius Rockwell, Davis wrote, "Every additional trip to Maryland confirms me in my desire to live in a free State." 54 As a conservative Republican, Davis vehemently opposed slavery and continued to see Abolitionists as "insincere demagogues striving for public office at the expense of the public weal." 55 Lincoln was extremely cagey in 1854-1856, but once the Whig Party was really most sincerely dead, he was willing to work with abolitionists. We do not see Davis as a civil libertarian at this point

${ }^{52}$ David Davis to Julius Rockwell, July 15, 1854, David \& Sarah Davis Family Correspondence, David Davis Mansion Historic Site, Bloomington, Illinois.

${ }^{53}$ Bader and Williams, "David Davis," 2-8.

${ }^{54}$ David Davis to Julius Rockwell, February 18, 1858, David \& Sarah Davis Family Correspondence, David Davis Mansion Historic Site, Bloomington, Illinois.

${ }^{55}$ King, Lincoln's Manager, 115. 
in his life though. He was more concerned with the people's welfare than with individual liberty.

This would change during the Civil War as concerns for individual civil liberties (for white men) impeded more heavily on his mind. In her 2008 dissertation entitled, "A Dilemma of Civil Liberties: Blacks under Union Military Control, 1861-1866, Karin Petlack argued that “when the Union Army suppressed white Americans' freedom of speech and threatened punishment for any sort of violent behavior during the war...the black community was able to establish black newspapers, expand their religious institutions, and increase educational offerings with little fear of assault." ${ }^{" 56}$ In other words, Petlack suggested that Black civil liberties could only be enforced by restricting White civil liberties. If they were not so enforced, white people would have infringed upon Black civil liberties. Lincoln was willing to side with Black rights of course, but Davis was not, yet he remained fervently antislavery.

Why then, did Davis oppose "political" abolitionists if he was in fact antislavery himself? Many Whigs, like Davis, were against "political" abolitionists not because of their goal to rid the country of slavery but rather because of their advocacy of violence to do so. This was a time in American history in which society on the prairie was changing and lawyers were the individuals making this change. Lawyers and judges were seeking social order. Therefore, Davis, as a man of the law, saw "political" abolitionist violence to be detrimental to law and social order that he and other jurists were attempting to

${ }^{56}$ Karin Petlack, “A Dilemma of Civil Liberties: Blacks under Union Military Control, 18611866," (PhD diss., University of California, Berkeley, 2013), 3. 
establish. Nor did Davis agree with abolitionist ideology in regards to black political rights. In a letter to Lincoln during the Lincoln-Douglas debates, Davis stated, "It is industriously circulated that you favor negro Equality. All the orators should distinctively \& emphatically disavow negro suffrage, negroes holding office, serving on juries \& the like." ${ }^{, 57}$ Lincoln famously took Davis's advice at the Charleston debate and in a rather convoluted way, distanced himself from Black equality, a position that, according to James Oakes lasted only until the First Inaugural, where Lincoln came out for extending equal privileges and immunities to Blacks. ${ }^{58}$ Davis, on the other hand, held these prejudicial views for the rest of his life. Still, when it came to ruling from the bench, Davis kept his views out of the decision-making process. Even during his time as a Circuit Court Judge, Davis dismissed a case in 1854 for an African American woman who had been arrested for disturbing the peace. She was released on her own recognizance..$^{59}$

In this context, we can then establish a political pedigree in which Davis's opposition to Radical Republicans stemmed more from his resistance to abolitionism, rather than simply anti-Partyism. This will become vital to understand later on when Radicals in Congress react to Milligan. In their minds, Davis's opinion jeopardized their ability to use military commissions to protect freedmen in a post-war South. Yet, as we

\footnotetext{
${ }^{57}$ David Davis to Abraham Lincoln, August 3, 1858, David \& Sarah Davis Family Correspondence, David Davis Mansion Historic Site, Bloomington, Illinois.

58 James Oakes, 'Natural Rights, Citizenship Rights, States' Rights, and Black Rights: Another Look at Lincoln and Race" in Eric Foner, ed., Our Lincoln (New York: W. W. Norton: November, 2008), 109-134.

${ }^{59}$ People v. Hill (June 12, 1854) "The Law Practice of Abraham Lincoln," http://www.lawpracticeofabrahamlincoln.org/Details.aspx?case=140070 accessed April 26, 2016.
} 
have seen, he equally opposed extremist Democrats. In 1863, Davis shared with his brother-in-law Julius Rockwell his disdain for Peace Democrats, just as he had opposed Locofocos in his early political career. "The Democratic party in this State [Illinois] is in the hands of Extreme men just as the ... Republican party of the U.S. is in the hands of the extreme Anti-Slavery men." ${ }^{\prime 0}$ Only a month before, Davis had written to his wife Sarah, complaining of Peace Democrats, or Copperheads, publicly denouncing Lincoln as a "tyrant \& despot" and "charging him with violating the Constitution and being a worse traitor than Jeff Davis." ${ }^{\prime \prime 1}$ Ironically, Milligan could be seen today as a Copperhead document in its chastisement of Lincoln and his extra-constitutional actions during the war.

The circumstances that resulted in the elevation of Davis to the Supreme Court had little to do with civil liberties but it is worth noting exactly how he did reach the highest court in the land. When Lincoln took office in 1861, he was faced with filling three vacancies on the Supreme Court. He was also faced with an impending national crisis. He chose to deal with the latter first. It was not until January 1862 that he turned his attention to the Court. Presidential appointments to the Supreme Court worked differently in the $19^{\text {th }}$ century, however. At the time, President Lincoln was restricted by law requiring every associate justice to represent one of the nine judicial circuits. Thus,

${ }^{60}$ David Davis to Julius Rockwell, April 8, 1863, David \& Sarah Davis Family Correspondence, David Davis Mansion Historic Site, Bloomington, Illinois.

${ }^{61}$ David Davis to Sarah Davis, March 1, 1863, David \& Sarah Davis Family Correspondence, David Davis Mansion Historic Site, Bloomington, Illinois. 
he had to fill the three vacancies with judges from the seventh, eighth, and ninth judicial circuits. $^{62}$

Even though Lincoln and Davis were very close friends and many thought Davis's nomination was a fait accompli, Lincoln hesitated in nominating him. Davis, himself, actually hoped that Lincoln would appoint him as a federal district court judge rather than a Supreme Court justice. Illinois Senator Orville Browning was in the running for the Supreme Court and very much appealed to the president. However, after being inundated with letters from friends and colleagues of both Lincoln and Davis, Lincoln finally made the decision to nominate Davis. The president made the offer to Davis in the summer of 1862 while Congress was out of session. ${ }^{63}$

Davis's feelings on his own recess appointment were not very optimistic. He doubted whether he could perform competently on the Supreme Court. This is understandable given the fact that all of his experience had been at the trial court level and largely dealt with the common law, rather than constitutional issues. He expressed his misgivings to a friend in January 1862. "I often doubt whether I could sustain myself on the Supreme Bench. It may be that I am not self-confident enough. I certainly could not without hard study. I have but little legal learning, and whether study would suit me now may be very doubtful."64 It can be fairly stated that Judge Davis had no particular judicial agenda when he assumed the Supreme Court. Yet, it was during his time as a

${ }^{62}$ Bader and Williams, "David Davis," 10.

63 Ibid., 11.

${ }^{64}$ David Davis to William Orme, January 27, 1862, David \& Sarah Davis Family Correspondence, David Davis Mansion Historic Site, Bloomington, Illinois. 
justice that he would emerge as a civil libertarian, drafting what many see as one of the greatest defenses of civil liberties in American jurisprudence.

Despite his own doubts about his judicial potential, Davis was confirmed by the Senate on December 8, 1862 and took the bench two days later. ${ }^{65}$ Early on in his tenure as associate justice, he expressed his continued disdain for partisan politics. "The labors of the Court are considerable, but I feel just now, as if I could get along with them, provided, I could keep out of politics \& visitors would let me alone."

Davis, though, intervened in cases involving civil liberties long before he ruled in Milligan. It is in this sub-plot that Davis emerged as a civil libertarian. Concerns about civil liberties issues had been raised very early in Lincoln's presidency beginning with the 1861 suspension of habeas corpus that resulted in Ex parte Merryman. In the days and months following Fort Sumter, Lincoln faced unprecedented events that required extraordinary actions. At that point, seven southern states had already seceded from the Union. On April 19, a mob in Baltimore obstructed Massachusetts troops from marching through the city, on their way to Washington. When word came that a special session of the Maryland legislature had been called, Republicans feared that a secession ordinance would be adopted. Lincoln held off on arresting the members of the Maryland legislature at first, but on April 27, he gave General Winfield Scott the following order:

You are engaged in repressing an insurrection against the laws of the United States. If at any point on or in the

\footnotetext{
${ }^{65}$ Bader and Williams, "David Davis," 11.

${ }^{66}$ David Davis to Leonard Swett, December 22, 1862, David \& Sarah Davis Family Correspondence, David Davis Mansion Historic Site, Bloomington, Illinois.
} 
vicinity of the military line, which is now used between the City of Philadelphia and the City of Washington, via Perryville, Annapolis City, and Annapolis Junction, you find resistance which renders it necessary to suspend the Writ of Habeas Corpus for the public safety, you, personally or through the officer in command at the point where the resistance occurs, are authorized to suspend that writ." 67

Nine members of the Maryland legislature were arrested before they could even have the opportunity to vote for or against secession. In The Fate of Liberty: Abraham Lincoln and Civil Liberties, historian Mark Neely argues that Lincoln's suspension of habeas corpus was not originally a political measure, nor would it become a political measure over the course of the war. For Neely, Lincoln was simply responding to military threats: the blockage of military troop routes and a Democratic-controlled state legislature.

Although Neely exonerated Lincoln of politically motivated wrong-doing, rogue military officers were also responsible for complicating civil liberties issues during the war. On August 30, 1861, Major General John C. Frémont issued a proclamation stating that circumstances in Missouri required a state of martial law. According to the proclamation, all persons within the prescribed military district found with weapons would be tried by court-martial. Fearing that the border state of Missouri would secede, Lincoln immediately ordered Frémont to rescind the proclamation. ${ }^{68}$ Military commissions were convened throughout Missouri in order to hear cases involving the

${ }^{67}$ Abraham Lincoln, Military Order, "Order to General Scott," April 27, 1861 quoted in Abraham Lincoln: Complete Works, Comprising His Speeches, Letters, State Papers, and Miscellaneous Writings, John G. Nicolay and John Hay eds., vol. II (New York: The Century Co., 1894), 39.

${ }^{68}$ Louis Fisher, "Military Tribunals: Historical Patterns and Lessons," Congressional Research Service Report for Congress (Washington D.C.: The Library of Congress, July 9, 2004), 18. 
destruction of railroads, railroad cars, and telegraph lines. On January 1, 1862, Major General Henry W. Halleck, acting on his own authority, stated that the civilian courts in Missouri, "can give us no assistance as they are very generally unreliable. There is no alternative but to enforce martial law." 69 To counteract many of these unauthorized military commissions, Lincoln reviewed the case proceedings and overturned them. However, these reviews were few and far between. He was much too preoccupied with the war in Virginia and thus in the words of Mark Neely, he "failed to act with sufficient decisiveness to meet Missouri's extraordinary problems, and civil liberties in that state were severely restricted by local military commanders for months before the president did anything.,"70

When Lincoln first suspended habeas corpus, it was geographically limited. Later, on September 24, 1862, he suspended the writ nationwide, mainly in response to draft dodgers. This second suspension encompassed "any person or persons who may be engaged, by act, speech, or writing, in discouraging volunteer enlistments, or in any way giving aid and comfort to the enemy, or in any other disloyal practice against the United States" and "that such persons may be tried before a military commission."71 Legal scholar Dan Farber noted, "Lincoln's use of habeas in areas of insurrection or actual war should be considered constitutionally appropriate, at least in the absence of any contrary action by Congress. But even after Congress authorized suspending habeas corpus, as we

\footnotetext{
${ }^{69}$ Fisher, "Military Tribunals," 19.

${ }^{70}$ Mark Neely Jr., The Fate of Liberty: Abraham Lincoln and Civil Liberties (New York: Oxford University Press, 1991), 32.

71 Abraham Lincoln, Military Order, “General Orders No. 104,” August 13, 1862, quoted in Neely, Fate of Liberty, 53.
} 
will see, the use of military law in the North sometimes went beyond constitutional limits.,72

For nearly two years, Congress remained on the sidelines but on March 3, 1863, Congress took Lincoln's side and passed the Habeas Corpus Act. In order to resolve jurisdictional problems like those posed in Merryman and later Milligan, Congress established that "during the present rebellion, the President of the United States, whenever in his judgement the public safety may require it, is authorized to suspend the privilege of the writ of habeas corpus in any case throughout the United States or any part thereof." 73 However, Congress did take care to provide some relief to those arrested under the suspension. The act provided that the Secretary of War was required to present a list of all prisoners to the civil courts. If a grand jury met without indicting said prisoners, those prisoners were to be immediately released from custody on the condition of taking a loyalty oath. ${ }^{74}$ Lincoln resisted using the act, believing that he did not need it. In May of 1863, when a group of New York Democrats criticized him for violating civil liberties, Lincoln via the Corning Letter, did not even reference the act to justify his actions. ${ }^{75}$ Yet, in September, when he suspended the writ again, Lincoln's order began by referring to both the Constitution and the act and ends by urging all citizens "to conduct and govern themselves ... in accordance with the Constitution of the United States and the

${ }^{72}$ Dan Farber, Lincoln's Constitution (Chicago: University of Chicago Press, 2003), 163.

${ }^{73}$ An Act relating to Habeas Corpus, and regulating Judicial Proceedings in Certain Cases, U.S. Statutes at Large 755 (1863).

${ }^{74}$ Ibid.

75 James A. Dueholm, "Lincoln's Suspension of the Writ of Habeas Corpus: An Historical \& Constitutional Analysis," Journal of the Abraham Lincoln Association 29, no. 2 (Summer 2008): 48. 
laws of Congress." 76 Here it appears that he was prepared to assert Constitutional and Congressional authority to suspend the writ.

The Habeas Corpus Act of 1863, though, did not explicitly prohibit military commissions. Commissions would therefore continue to be the primary judicial instrument for the duration of the war and largely remain unregulated by either the legislative or sometimes even the executive branch. Lincoln's task as President during the war was so vast that he was forced to delegate power to state and local officials. The governor of Indiana and the military commanders appointed there by the War Department were given broad authority to quell Copperhead dissent, which in turn led to the military trial of Milligan and his co-defendants.

It appears Davis first began to show concerns about the direction of the Lincoln administration was taking on Northern civil liberties issues in the winter of 1862 . In November 1862, Davis brought with him a letter from Judge Samuel Treat of St. Louis, who had issued a writ of habeas corpus for a civilian which the military had refused to acknowledge. Like Davis, Treat was a close personal friend of Lincoln's and his chess partner in Springfield. ${ }^{77}$ Lincoln had pled over 1,200 cases before Judge Treat at both the trial and appeals level. In his letter to Davis, Judge Treat advised Lincoln to act within the Constitution so as to increase support in the Border State of Missouri. He also suggested that the President send the entire western army to secure the Mississippi. ${ }^{78}$ In

\footnotetext{
${ }^{76}$ Abraham Lincoln, Presidential Proclamation, "Suspension of the Writ of Habeas Corpus," September 25, 1862 quoted in Dueholm, 49.

77 Jesse Weik, The Real Lincoln: A Portrait (Boston: Houghton Mifflin, 1923), 102-103.

${ }^{78}$ Samuel Treat to David Davis, November 5, 1862, in King, Lincoln's Manager, 204.
} 
response, Lincoln wrote Treat stating that "the country will not allow us to send our whole Western force down the Mississippi, while the enemy sacks Louisville and Cincinnati." ${ }^{, 79}$ While Lincoln did not even mention the habeas corpus issue in his response to Treat, the fact that Davis presented Treat's letter to him strongly suggests he was concerned about civil liberties five weeks before he took his seat on the Supreme Court.

Thus was the Northern civil liberties landscape that Davis faced during the first two years of the war. It is also important to note that he supported Lincoln's war-time actions in the South. In the Prize Cases, Davis along with Grier, Wayne, Swayne, and Miller upheld Lincoln's naval blockade of the South. ${ }^{80}$ This case confirmed the legitimacy of treating the Confederacy as a belligerent under the laws of war which in turn justified the sweeping use of the commander-in-chief clause, among other things, to confiscate Confederate property, including the emancipation of slaves, and to use military commissions.

Davis did, however, take exception to one Southern war measure: the Emancipation Proclamation. This makes sense in light of Davis's own racial prejudices.

${ }^{79}$ Abraham Lincoln to Samuel Treat, November 19, 1862, Collected Works of Abraham Lincoln, Roy Basles, ed. Vol. 5 (New Brunswick, N.J.: Rutgers University Press, 1953), 501. Louisville served as the main hub for planning, supplies, recruiting, and transportation for the Western Theatre of the war. Stephen I. Rockenbach, "A Border City at War: Lousiville \& the 1862 Invasion of Kentucky" Ohio Valley History 3, no. 4 (Winter 2003):35-52. In July 1862, Confederate General Braxton Bragg launched an invasion of Kentucky. His objective was to sever Union supply routes on the Ohio River via the Louisville \& Portland Canal. Cincinnati served as a center of supplies and troops for the Union Army and was the Headquarters for the Department of the Ohio. In September 1862, Confederate General Henry Heth marched on the city. Upon facing strong Federal lines, he decided not to attack. Gail Stephens, "This City Must Not Be Taken," Traces of Indiana \& Midwestern History 22, no. 2 (Spring 2010): 4-17.

${ }^{80}$ The Brig Amy Warwick, The Schooner Crenshaw, The Barque Hiawatha, and The Schooner Brilliante, 67 U.S. 635 (1863). 
On one occasion, he told Lincoln that issuing the proclamation would be counterproductive to the war. Nothing is said about a meeting with Lincoln in the Davis papers on this issue, but according to Orville H. Browning, a friend of both Davis and Lincoln, "Judge Davis...told me that he had a conversation with the President yesterday and urged upon him to change his policy, as the only means of saving the Country." In response, Lincoln stated, "his proclamation in regards to slavery was a fixed thing." 81 Six months later, in a letter to his brother-in-law Julius Rockwell, Davis blamed Lincoln's proclamation for the Border States' discontent with the war. "In the Western Country until the Emancipation Proclamation, the people were united in the support of the WarNow, they are divided." 82 Other than this particular issue, Davis consistently upheld Lincoln's war-time actions when it came to the southern states in rebellion. His actions in the North, however, concerned Davis greatly.

Soon thereafter, in the spring of 1863 , Davis intervened with Lincoln again in a civil liberties issue. In March of that year, Wilber F. Storey, editor of the Chicago Times, began publishing editorials vehemently criticizing the Lincoln administration and encouraging Northerners to protest its war policies, especially the Emancipation Proclamation. The Times frequently ran supposed letters from soldiers, voicing their opposition to abolitionism. Storey brought to the newspaper a seething hatred for blacks and abolitionists that he extended to the Republican Party and the Lincoln administration

${ }^{81}$ Orville Hickman Browning, January 17, 1863, The Diary of Orville Hickman Browning, ed. Theodore Pease and J. G. Randall (Springfield: Illinois State Historical Library, 1925), 616.

82 David Davis to Julius Rockwell, July 1, 1863, David \& Sarah Davis Family Correspondence, David Davis Mansion Historic Site, Bloomington, Illinois. 
as well. On March 17, Storey called for "a united, bold, vigorous, unyielding opposition to the prosecution of the war." 83 In response, General Ambrose Burnside, Commander of the Department of Ohio, finally ordered the Times shut down on June 1. Public outrage was immediately felt in response to Burnside's action. Several politicians pleaded with Lincoln to rescind Burnside's order. David Davis and William Herndon, Lincoln's old law partner from Springfield, sent Lincoln a telegram stating, "We deem it of the highest importance that you revoke the order ... suppressing the Chicago Times." 84

In "To Suppress or Not to Suppress: Abraham Lincoln and the Chicago Times," Craig D. Tenney suggests that it was Davis and Herndon's telegram that convinced Lincoln to rescind Burnside's order. "It would appear from...the Davis-Herndon telegram that Lincoln...had already felt what to him would be rather weighty political pressure to negate Burnside's action against the Times." ${ }^{85}$ On June 4, Lincoln wrote to Secretary of War Edwin Stanton ordering him to rescind the suppression of Storey's newspaper. "I have received additional dispatches which with former ones [the DavisHerndon message] induce me to believe we should revoke or suspend the order suspending the Chicago Times, and if you concur in [this] opinion, please have it done." ${ }^{\prime 66}$ No correspondence exists that emphatically states that it was Davis and Herndon's letter that finally convinced Lincoln but Davis continued to voice his concerns

${ }^{83}$ Chicago Times, March 17, 1863 quoted in Craig D. Tenney, "To Suppress or Not to Suppress: Abraham Lincoln and the Chicago Times," Civil War History Vol. 27 No. 3 (September 1981), 252.

${ }^{84}$ David Davis and William Herndon to Abraham Lincoln, June 2, 1863 quoted in Tenney, 255.

${ }^{85}$ Craig D. Tenney, "To Suppress or Not to Suppress: Abraham Lincoln and the Chicago Times," Civil War History Vol. 27 No. 3 (September 1981), 255.

${ }^{86}$ Abraham Lincoln to Edwin Stanton, June 4, 1863, quoted in Tenney, 256. 
about civil liberties issues as the war progressed. During this time and in the context of the Civil War, Davis evolved into a civil libertarian.

Storey's situation also closely relates to the issues in Milligan. As we will see, Lambdin P. Milligan was convicted not on evidence relating to a conspiracy to overthrow the government, but rather on one single published speech in which he criticized the Northern war effort. No doubt, this intervention by Davis reflected his growing concern with government actions he felt to be constitutionally questionable. In addition to shutting down newspapers, silencing speech, and suspending habeas corpus, Davis also began to intervene on behalf of Copperheads who faced trial by military commissions.

In May 1863, while sitting as circuit judge in Indianapolis, Davis wrote to a Grand Jury:

Gentlemen of the Grand Jury: We meet in a time of great national peril-in the midst of a war, unexampled for its wickedness and magnitude. Our own honor-the treasure that has been spent-the blood that has been shed-the memories of the past, and the hopes of the future demand that this rebellion shall be crushed, the union of these States restored, and the authority of law recognized. We may, and will differ, in any great war, on the right manner of conducting it, and the wisdom of the policy pursued, but no man, who is not a traitor at heart, will ever suffer that difference to lead him by speech or writing of counsel resistance to law. It is charged that there are secret organizations with 'grips, signs, and passwords' having for their objects-resistance to Law, and the overthrow of the Government. If anywhere in this State bad men have combined together for such wicked purposes, I pray you, bring them to light and let them receive the punishment due to their crime. ${ }^{87}$

${ }^{87}$ Indianapolis Journal, May 8, 1863, quoted in King, Lincoln's Manager, 248. 
The jury asked for a copy of the judge's charge so they could publish it in the

Indianapolis Journal. Here, Davis again supported the war and punishing those who obstructed its progress, but at the same time insisted that the law be respected. Once more, this illustrates Davis's later intention of only applying Milligan's holding to military commissions in the North.

At the same time Davis was holding court in Indianapolis, Clement L.

Vallandigham was being tried by a military commission in Ohio for making a speech against the war effort. When his case reached the Supreme Court, Vallandigham's petition was denied. The Court reasoned that:

The appellate powers of the Supreme Court, as granted by the Constitution, are limited and regulated by the acts of Congress, and must be exercised subject to the exceptions and regulations made by Congress. In other words, the petition before us we think not to be within the letter or spirit of the grants of appellate jurisdiction to the Supreme Court. It is not in law or equity within the meaning of those terms as used in the $3 \mathrm{~d}$ article of the Constitution. Nor is a military commission a court within the meaning of the 14th section of the Judiciary Act of 1789. [Power of the Supreme Court to grant writs of habeas corpus] Nor can it be said that the authority to be exercised by a military commission is judicial in that sense. It involves discretion to examine, to decide and sentence, but there is no original jurisdiction in the Supreme Court to issue a writ of habeas corpus to review or reverse its proceedings, or the writ of certiorari to revise the proceedings of a military commission. ${ }^{88}$

${ }^{88}$ Ex parte Vallandigham, 68 U.S. 1 Wall. 243253 (1863). 
It is important to note that while the Court did not accept Vallandigham's case based on a technical jurisdiction matter, they rejected the ideas that military commissions were judicial bodies. According to Davis's biographer, Willard King, Justice Davis later stated in private that Vallandigham's trial by military commission had been wrong. ${ }^{89}$ However, King's citation for this alleged comment by Davis came from William Herndon and Jesse Weik's Herndon's Lincoln. In cross checking this citation, Herndon's book does not make mention of Davis stating that he thought Vallandigham's military commission was wrong. It appears that King miscited Herndon or perhaps misread him. Additionally, no other primary source indicates that Davis ever made such a statement, but one could adduce from his concern over civil liberties especially military commissions, that he could have done so.

Violent riots in the North began to grow in resistance to the Enrollment Act of 1863. In March, Brigadier General Henry B. Carrington was appointed to the District of Indiana and worked closely with Indiana Governor Oliver P. Morton to organize and train troops to suppress uprisings. He also developed a very intricate espionage network that kept Morton and Lincoln informed of Copperhead activity in Indiana. This close working relationship became tenuous however when General Ambrose E. Burnside was put in command of the Department of Ohio, of which Indiana was a part. On April 13, 1863, Burnside issued General Orders No. 38, prescribing strict military punishment for any person who opposed the federal government and sympathized with the Confederacy.

${ }^{89}$ King, Lincoln's Manger, 254. 
Morton was infuriated over Burnside's action. He was afraid that this extreme order would just fuel more resistance to the government. Yet, Morton remained publically silent, that is until his right-hand man General Carrington was fired by Burnside. General Milo S. Hascall, Carrington's replacement, immediately began to arrest Democratic newspaper editors and destroy their presses. Morton went from infuriated to seething. Hascall's actions did not eliminate Peace Democratic (Copperhead) opposition however; it only strengthened the anti-war sentiment in Indiana. ${ }^{90}$

In response, Morton embarked on a crusade to have both Burnside and Hascall removed from command. In doing so, he turned to Justice David Davis for help. Davis personally telegraphed Secretary of War Edwin Stanton, stating, "I have been for several weeks, and am, perfectly satisfied that the immediate removal of General Hascall is demanded by the honor and interests of the Government." ${ }^{\text {91 }}$ Over the next month, Morton made several trips to Washington City to press Lincoln to remove Burnside and Hascall. Burnside remained in command but Stanton finally relieved Hascall in June. It would be inaccurate to view Morton as a defender of Indiana's freedom of the press and speech however. As we will see in the case of Lamdin P. Milligan, Governor Morton would go on to arrest Copperhead editors and speakers himself. ${ }^{92}$

Davis was of course not the only one who was becoming concerned about civil liberties issues. It is therefore important to briefly delve into the range of opinions on

${ }^{90}$ Stephen E. Towne, "Killing the Serpent Speedily: Governor Morton, General Hascall, and the Suppression of the Democratic Press in Indiana, 1863," Civil War History 112, no. 1 (March 2006): 55-56. 58.

${ }^{91}$ David Davis to Edwin Stanton, May 27, 1863, quoted in Towne, "Killing the Serpent Speedily,"

${ }^{92}$ Towne, "Killing the Serpent Speedily, 64-65. 
civil liberties during the war. Democrats, especially Copperheads, obviously made these concerns one of their primary causes. An 1864 Indiana case involving selling liquor to soldiers, prefigured David Davis' decision in Ex parte Milligan. On June 8, 1863, the chief provost marshal of the military District of Indiana ordered Indianapolis provost marshal Captain Frank Wilcox to prohibit the sale of liquor to enlisted soldiers. Joseph Griffin was subsequently arrested for violating the order. He sued Wilcox for false imprisonment. After losing his case in the Marion County Common Pleas Court, Griffin appealed to the Indiana Supreme Court. Peace Democrat Judge Samuel E. Perkins delivered a scathing opinion on military arrests of civilians.

Perkins' concern was not whether Lincoln could arrest and hold civilians indefinitely by suspending habeas corpus, but rather applying military law to civilians. He noted that the suspension of habeas corpus did not legalize a wrongful arrest; it simply prohibited the prisoner his right to challenge his detention. While he did not address whether Congress could enact martial law, Perkins did define the conditions for martial law. "Martial law is exercised in our country, the military being on the spot to execute it, where no civil authority exists. But where the civil authority exists, the Constitution is imperative that it shall be paramount to the military." ${ }^{93}$ Perkins' opinion would slightly mirror Davis's opinion two years later in Ex parte Milligan. We cannot know for certain but it may be that Davis adopted Perkins' opinion when he drafted

${ }^{93}$ Neely, The Fate of Liberty, 87. 
Milligan, for they both recognized the supremacy of the U.S. Constitution in times of war and peace and that martial law can only be implemented in areas of actual hostilities.

It is also important to note that Justice Perkins was fundamentally at odds with Republicans about civil liberties. We already know Lincoln's position: the constitution provided him with vast war powers, especially in the face of rebellion. In his famous “Corning letter" Lincoln explains, "Must I shoot a simple-minded soldier boy who deserts, while I must not touch a hair of a wiley agitator who induces him to desert? I think that in such a case, to silence the agitator, and save the boy, is not only constitutional, but, with all, a great mercy." ${ }^{94}$ Lincoln felt that Copperheads posed a real threat in the form of diminishing the ranks. Rather than diminish the ranks himself by executing deserters, Lincoln felt it necessary to eliminate the source of desertion. Davis understood the threat of Peace Democrats as well, but he, unlike Lincoln, never believed that civil liberties in the North should be sacrificed in the interest of prosecuting the war in the South. While it is mere speculation, given Davis's logic, he might have supported shooting the simple-minded soldier boy rather than arrest the wiley agitator and risk violating his constitutional right to a civilian trial.

Harvard Law professor and War Democrat Joel Parker, on the other hand, came to the defense of Lincoln's actions regarding civil liberties. He argued that habeas corpus was not the same in war and peace. Even though civilian control of the military was defined in the constitution, it could not be applied to camps or battlefields. Civil law

94 "Corning Letter," quoted in Mark Neely, Jr., Lincoln and the Triumph of the Nation, 86. 
simply could not be used in these places. Therefore, martial law naturally existed during wartime by virtue of the laws of war. For Parker, it all came down to a matter of practicality. He pointed out the harmful and dangerous result of allowing the halt of the military but civil courts. ${ }^{95}$ Henry Stanbery, attorney for the government in Milligan, would make a similar argument in defense of that particular military commission.

Likewise, Republican attorney and Congressman from Pennsylvania, Horace Binney, offered a defense of Lincoln's suspension of habeas corpus. In his 1862 pamphlet, The Privilege of the Writ of Habeas Corpus under the Constitution, Binney avoided using circumstantial arguments based on the desperate times of the Civil War. Nor did he plea morality or politics in supporting Lincoln's actions. He stated:

The power to suspend the privilege of the Writ, is moreover inseparably connected with rebellion or invasion, - with internal war. The direction of such a war is necessarily Avith the Executive. The office cannot be deprived of it. It is the duty of the office, in both its military and civil aspects, to suppress insurrection, and to repel invasion. The power to suspend the privilege, is supplementary to the military power to suppress or repel. ${ }^{96}$

For Binney then, the crux of when to suspend the writ lay with conditions-invasion or rebellion. He argued that those were not same conditions as "war", which Congress possessed sole authority to declare. Instead, invasion and rebellion were factual

${ }^{95}$ Neely, Lincoln and the Triumph of the Nation, 66-67.

${ }^{96}$ Horace Binney, The Privilege of the Writ of Habeas Corpus under the Constitution (Philadelphia: Sherman \& Sons, 1862), 8. 
conditions to be identified and dealt with immediately, whether Congress was in session or not. Logically then, the power to suspend habeas corpus fell to the president.

For his part, Justice Davis made clear to Lincoln his position on military commissions, as they became an emerging civil liberties issue. Writing to William Herndon, Lincoln's former law partner, in September 1866, Davis reflected:

Mr. Lincoln was advised and I so advised him, that the various military trials in the Northern and Border States, where the Courts were free and untrammeled, were unconstitutional and wrong; that they should not and ought not to be sustained by the Supreme Court; that such proceedings were dangerous to liberty. ${ }^{97}$

Notice that Davis narrowed his opposition to military commission to the North and Border States. He said nothing about military commissions in the South.

Not only did Davis advise the President against the use of military commissions in the North and Border States, he also directly intervened on behalf of civilian defendants who were put on trial before military commissions. On March 28, 1864, in Charleston, Illinois, mounting hostility between Coles County Peace Democrats and Union soldiers on leave finally came to a head. These soldiers had long resented Peace Democrats for criticizing a war in which they themselves had fought and sacrificed so much for. Encouraging draft dodging, too, infuriated Union soldiers. This animosity

${ }^{97}$ David Davis to William Herndon, September 1866, David \& Sarah Davis Family Correspondence, David Davis Mansion Historic Site, Bloomington, Illinois. 
boiled over into a riot in late March which left six soldiers and three civilians killed and twelve wounded. To be sure, it was one of the bloodiest riots in the North. Over the next several days, fifty citizens were arrested and about one hundred depositions were taken from other Coles County residents. In the end, sixteen prisoners were incarcerated at Camp Yates in Springfield. One prisoner died while in custody. ${ }^{98}$

In June, a Coles County grand jury returned fourteen indictments against Copperheads for murder and riot. However, only two were indicted for murder and two were indicted for rioting. The other prisoners had escaped and fled the area. The legal prosecution, however, followed two paths. The military, based on a recommendation from Judge Advocate General Henry Burnett, a military commission was appointed to try the prisoners in Cincinnati, Ohio, on June 21, 1864. Meanwhile, Attorneys Orlando B. Ficklin and Milton Hay were working feverously to get the unindicted prisoners released and the indicted prisoners handed over to civil authorities. On June 22, Ficklin and Hay requested a writ of habeas corpus from the Fourth Circuit Court, where Judge Samuel H. Treat was presiding alongside David Davis who was on the circuit. ${ }^{99}$

Treat and Davis granted the writ which was then given to Colonel James Oakes, commandant of Camp Yates, with instructions to release the prisoners and deliver them to Springfield. However, Oakes had just been ordered by his superiors to deliver the men to Cincinnati for military trial. The next day Oakes was informed by his commanding officer that President Lincoln had suspended habeas corpus in the Coles County

\footnotetext{
${ }^{98}$ Peter J. Barry, "'I'll keep them in prison awhile...': Abraham Lincoln and David Davis on Civil Liberties in Wartime," Journal of the Abraham Lincoln Association Vol. 28., No. 1, (2007), 21.

99 Barry, "I'll keep them in prison awhile," 22.
} 
prisoner's case. Judge Davis was in St. Louis when this transpired, but Judge Treat, honoring the President's suspension, dismissed the case. When Davis learned about the suspension, he expressed his displeasure in a letter to Lincoln on July 1, 1864, stating:

The govt (sic) I think must have acted on the wrong information. If I could get the necessary correct information concerning the matter either for bringing it to the President myself or do it in confirmation with Judge Treat, as might be deemed most advisable. ${ }^{100}$

At this point in the exchange of correspondence, Davis did not provide an explanation as to what he meant by "wrong information" but this incident again illustrates his increasing concern for Lincoln's actions regarding civil liberties.

Not knowing that Davis had sent this letter, Lincoln wrote Treat the following day requesting that he and Davis send him their analysis of the case. In response, Judge Treat sent Lincoln a telegram on July 4 stating:

The record in the case of the Coles Co prisoners was ordered to be certified to the president it contains the whole case in my opinion the prisoners should have been surrendered to the civil authority under the act of March Third (3) eighteen sixty three (1863) Judge Davis was of the same opinion. ${ }^{101}$

100 Davis to Lincoln, July 1, 1864, Letters Received by the Office of the Adjutant General (Main Series), 1861-1870 (M619), roll 285, National Archives and Records Administration, Washington, D.C. ${ }^{101}$ Treat to Lincoln, July 4, 1864, The Abraham Lincoln Papers at the Library of Congress. https://memory.loc.gov/cgi-bin/query/P?mal:1:./temp/ ammem_USID. 
On the same day, Davis wrote a four-page letter to Lincoln summarizing the evidence and providing his reasoning and statutory law for the release of the prisoners. Davis adamantly stated:

The Govt. (sic) ought not to have taken these men out of the hand of the law. Besides the disregard of the law as I think, it will irritate the public mind and cannot possibly do any good. A Grand Jury of Coles Co. has patiently investigated the outrage at Charleston and found several indictments for murder and riot. ${ }^{102}$

Here, it seems that Davis was trying to convince Lincoln that the local civilian court had competently performed its duty by issuing the indictments. Therefore, a military trial was not necessary. David continued with his reasoning by stating:

The guilty should be punished. Both certainty and severity of punishment are demanded, where it can be measured out if I understand the case a right only in a state court. These prisoners violated no law of the United States. There was no attempt to arrest a deserter. The fight was brought on purposely by bad men who were not in the military service. How can they be tried by military law? They violated no military law. ${ }^{103}$

Davis did not question whether the prisoners should have been punished. His only concern was that they were tried in the proper civilian court system, as they were civilians themselves and not under the authority of the military. Davis concluded his opinion to Lincoln by referencing the Habeas Corpus Act of 1863 :

102 Davis to Lincoln, July 4, 1864, Letters Received by the Office of the Adjutant General (Main Series), 1861-1870 (M619), roll 285, National Archives and Records Administration, Washington, D.C. ${ }^{103}$ Ibid. 
But even if they had violated a law of the United States, it was the duty of the govt. after they were arrested to have had them prosecuted at the first term of the court. Court adjourned and no proceeding was had against them \& as far as the United States were concerned, they were entitled to their discharge. The Secretary of War furnished no list of the prisoners to the judges which should have been done, and the Grand Jury adjourned. ${ }^{104}$

It is interesting to note that Davis did not appeal to the prisoner's civil liberties via the Bill of Rights. This particular intervention is solely based upon constitutional and statutory law. Milligan though, would be the turning point for constitutional liberalism and the supremacy of the Bill of Rights over military law and the laws of nations. Davis was successful in his intervention for the Coles Co. Peace Democrats. Finally, on November 4, 1864, Lincoln ordered the release of the prisoners.

Even though Davis was concerned about the mass uprising of Peace Democrats, he was not willing to sacrifice their civil liberties in the interest of stamping out dissent. This attention to the rule of law would be carried on into his majority opinion in Milligan. A law and order Whig early in life, Davis became concerned with civil liberties issues, specifically military commissions, over the course of the American Civil War. It is clear that Davis strongly criticized Lincoln's actions despite their close friendship. He would also take Lincoln to task after he was assassinated in Milligan. Davis was not afraid to express his concerns and objections to civil liberties issues in the North from a nonpartisan, constitutional standpoint. While he strongly opposed extremist political groups, 
like the Copperheads, he nevertheless stood up for their civil liberties. After directly intervening in free speech, habeas corpus, and military commission cases while on the Supreme Court, Davis would soon have another opportunity to place his imprimatur for the defense of civil law over military law. Alongside eight other justices, in the winter of 1865, he would hear arguments in Ex parte Milligan that sowed the seeds for not only one of the greatest defenses of American civil liberties, but also the worsening of Reconstruction partisan politics. But first, we must look back to how Lamdin P. Milligan's case came to the attention of Judge David Davis to begin with. 


\title{
CHAPTER III
}

\section{GUILTY BY ASSOCIATION: THE INDIANAPOLIS TREASON TRIAL AND EX PARTE MILLIGAN}

\begin{abstract}
It should be noted from the outset that no testimony or direct evidence was introduced that linked Milligan to the plot in Chicago or that he was at any meeting in which the plot was discussed. Witnesses simply stated that he had been to several organizational meetings with the other defendants and had accepted the rank of MajorGeneral as a member of the Sons of Liberty. ${ }^{105}$ Testimony did suggest that this organization was, in fact, a clandestine, para-military arm of the Democratic Party. One witness stated that the purpose of the Sons of Liberty was to uphold Democratic principles and strengthen the party, while another stated that members were required to be Democrats. In in his majority opinion in Ex parte Milligan David Davis would later object to several elements of the Military Commission. Understanding these aspects of the military trial will allow us to better understand why Davis ruled the way he did and why the Radical Republicans viewed his decision adversely.
\end{abstract}

${ }^{105}$ Klaus, The Milligan Case, 259. 
Born on March 24, 1812 in Belmont, Ohio, Lamdin Purdy Milligan came of age during the nullification crisis of 1832-1833. ${ }^{106}$ This would have a significant impact on his political leanings. In February 1834, at age twenty-one, Milligan served as secretary for the "Original Jacksonians" in St. Clairsville, Ohio. The group subscribed themselves to the "Jeffersonian school of '98 and '99 (the Kentucky and Virginia Resolutions of 1798 and 1799-two documents upholding states' rights). Early on, Milligan fully supported Jackson's defense of states' rights but then took a less supportive attitude towards him after Jackson's 1833 "Force Bill", a piece of legislation that would have given the president power to enforce federal authority in South Carolina.

Notwithstanding, Milligan remained loyal to Jackson while blaming his decisions on bad advisors. ${ }^{107}$ Milligan's desire and training to be an attorney is unclear but we do know that on October 27, 1835 he passed the Ohio bar examination. He was among a group of nine new lawyers that day, one of which included Edwin M. Stanton. ${ }^{108}$ In April 1838, Milligan was selected as a county delegate to the Democratic Convention where he spoke out against banks and supported the South's constitutional right to slavery. ${ }^{109}$ In the fall of 1845, Milligan moved to Huntington County, Indiana where he repeatedly failed in various elections as a Democrat. By this time, he had established himself as a proslavery, Northern Democrat sympathizer of the South. In 1848, Milligan sought the nomination for state senator but lost and in 1850 sought the nomination for state representative but

\footnotetext{
${ }^{106}$ Stephen E. Towne, "The Persistent Nullifier: The Life of Civil War Conspirator Lambdin P. Milligan," Indiana Magazine of History 109 (December 2013): 307.

${ }^{107}$ Towne, "The Persistent Nullifier," 309-310.

${ }^{108}$ Ibid.,308.

${ }^{109}$ Ibid., 311.
} 
lost again. For the next eight years he returned to the full-time practice of law before he was elected Huntington Township Trustee in $1858 .{ }^{110}$ In 1860 , he again attempted higher office when he sought the nomination for attorney general but lost once more. With public office continuing to evade him, Milligan decided to put his political energies toward another Democrat. He vigorously campaigned for Stephen Douglas but after the election Milligan took a strong-pro secession stance. ${ }^{111}$

From its very outset, Milligan vehemently opposed the war and made it his life's work to do everything he could to protect the Constitution's "first principles": the constitutionality of slavery and the rights of nullification and secession. Shortly after the attack on Fort Sumter, one local Huntington County resident noted, "Mr. Milligan even went so far as to say that he would rather spit upon the stars and stripes than to see them at the head of an army marching."112 Even his own neighbors questioned his loyalty. Milligan began to make a name for himself among Peace Democrats, or Copperheads, accepting invitations to speak across northern Indiana and giving speeches to large and eager audiences while passionately declaring his message of resistance to the draft, the Emancipation Proclamation, and Lincoln's suspension of habeas corpus. He was even so bold as to urge the Northwest to secede from the Union and ally itself with the Confederacy. By the end of the summer, Republican governors of Ohio, Indiana, and Illinois were increasingly concerned about the growing threats of insurrection by

\footnotetext{
${ }^{110}$ Ibid., 312-318.

111 Ibid., 319-321.

112 Ibid, 320.
} 
Milligan and other like-minded Copperheads. From the very start of the war many Southerners hoped that a series of victories would sow a seed of defeatism among Northwestern states such as Indiana, Illinois, and Missouri, leading to their desertion of the Union war cause. Many Northern Copperheads strongly believed in this possibility and laid plans to formulate a "Northwestern Confederacy."113

In Indiana's 1862 congressional elections, Democratic candidates seized onto the public resentment of the Lincoln administration's actions regarding the Emancipation Proclamation, military arrests, and suppression of the Democratic press. Indiana Democrats took back control of both chambers of the General Assembly. When the new General Assembly opened in January 1863, the Democrats vowed to remove Indiana's Republican governor, Oliver P. Morton from office. ${ }^{114}$ Indiana Republicans of course resisted Democratic attempts at seizing the governor's wartime powers. By bolting from the statehouse, Republicans denied Democrats a quorum. This successfully sidelined the Copperheads and negated their electoral victory, but it also meant there could be no constitutional state budget. Instead of recalling the legislature to fund the state, Governor Morton received funds from the War Department, Republican county governments, and private bankers in New York. In effect, Morton illegally ran the State of Indiana without the Democrats, leading to even more Copperhead disaffection. ${ }^{115}$

113 Ibid., 325.

114 Stephen E. Towne, "Worse than Vallandigam: Governor Oliver P. Morton, Lambdin P. Milligan, and the Military Arrest and Trial of Indiana State Senator Alexander J. Douglas During the Civil War," Indiana Magazine of History 106 (March 2010), 7.

115 Towne, "Killing the Serpent Speedily," 45. 
Past scholarship on Copperheadism has downplayed the threat of this group, particularly Richard O. Curry and Frank L. Klement who argued that perceived Copperhead anti-war activity was simply a product of Republican propaganda used to snuff out political dissent. ${ }^{116}$ Mark Neely, in The Fate of Liberty, argued that the Copperhead threat was exaggerated. ${ }^{117}$ However, in 2006, Jennifer Weber's book Copperheads: The Rise and Fall of Lincoln's Opponents in the North showed that Northern anti-war sentiment was so strong that Peace Democrats almost took control of the entire party in 1864. She also pointed out that the Copperheads were very effective in undermining Northern military manpower and that in response Lincoln had to divert troops to New York to quell the anti-draft rioters in 1863. ${ }^{118}$ Archivist Stephen Towne's 2015 book, Surveillance and Spies in the Civil War: Exposing Confederate Conspiracies in America's Heartland, is the most comprehensive study of Copperheadism to date. Steeped in archival material, this book echoes Weber, in that there was, in fact, an actual and present Copperhead threat in the state of Indiana during the Civil War. Through the lens of U.S. Army intelligence operations, Towne uncovers plot after plot, aimed at not only disrupting Lincoln's war effort but bringing the war to an end. ${ }^{119}$

\footnotetext{
${ }^{116}$ See Richard O. Curry, "Copperheadism and Continuity: the Anatomy of a Stereotype," Journal of Negro History 57, no. 1 (January 1972): 29-36, Frank L. Klement, Copperheads in the Middle West (Chicago: University of Chicago Press, 1960), and Frank L. Klement, Dark Lanterns: Secret Political Societies, Conspiracies, and Treason Trials in the Civil War (Baton Rouge: Louisiana Press University, 1989).

${ }^{117}$ Neely, Fate of Liberty, 64.

${ }^{118}$ See Jennifer L. Weber, Copperheads: The Rise and Fall of Lincoln's Opponents in the North (Oxford: Oxford University Press, 2006).

${ }^{119}$ See Stephen E. Towne, Surveillance and Spies in the Civil War: Exposing Confederate Conspiracies in America's Heartland (Athens: Ohio University Press, 2015).
} 
Weber and Towne's assessments of Copperheads as a real and serious threat to the Northern war effort echoed nineteenth century Republican opinion. On July 12, 1864 James A. Sheahan, of the Chicago Post, wrote

All people will recollect [that the Northwestern Confederacy] was a common topic of conversation in the spring of 1862 among 'Northern men of Southern principles,' who scouted the idea that Grant would take Vicksburg as they are now pooh-poohing the idea that he will take Richmond. In all the larger cities of the Northwest, and in many of the smaller ones, these Northwestern Confederacy disunionists were bold in avowing and vociferous in advocating the traitorous scheme. $^{120}$

What exactly was this traitorous scheme? According to federal agents, Lambdin P. Milligan, and other Copperheads like him, planned to overthrow state governments by stealing a cache of army issue arms and liberating several prisoner-of-war camps, starting with Camp Douglas in Chicago during the Democratic National Convention in August 1864. Milligan and his co-defendants were all members of the Sons of Liberty, a clandestine Copperhead organization, led by Clement L. Vallandigham, dedicated to helping the South win the war by carrying out paramilitary operations. Testimony at Milligan's trial further suggested that the organization was also in communication with Richmond, which sent agents from Canada with money to pay certain designated Copperhead leaders to formulate uprisings. ${ }^{121}$ To be sure, the testimony that was offered during the Military Commission was dubious at best. Witnesses provided vague and

\footnotetext{
${ }^{120}$ Quoted in Alan Nevins, "The Case of the Copperhead Conspirator," in Quarrels that have Shaped the Constitution, ed. John A. Garraty, (New York: Harper-Perennial, 2009), 110.

${ }^{121}$ Bradley, "The Story of Ex parte Milligan," 106.
} 
conflicting accounts of the times and locations of numerous Sons of Liberty meetings and the issues discussed at those meetings. A large portion of the trial consisted of character testimony, delving into the trustworthiness and patriotism of the defendants rather than actual evidence that would pin them to an actual conspiracy.

In addition to opposing emancipation and black equality, Copperheads saw themselves as the political descendants of Jackson and Jefferson, who both at least rhetorically supported limited government. Like Jackson and Jefferson, Copperheads grounded themselves in a relatively libertarian-sounding variant of republicanism, fearing tyranny and usurpation from the Federal Government, and upholding a "strict construction" of the Constitution. It is understandable that their rhetoric concerning government power and the Constitution harkened back to the Anti-Federalists and Jefferson's subsequent conflict with Hamilton. Of course, along with their political convictions, Copperheads, or Peace Democrats, simply wanted the war to be over and Blacks to remain enslaved in the South. While they were generally sympathetic toward the South, they envisioned a united country, not a divided one. Together with their political roots and wartime goals, their slogan became, "The Constitution as it is, the Union as it was, and the nigger where he belongs." 122

Additionally, Copperheads can be generally considered the militant wing of the Peace Democrats, but among Republicans that line was somewhat vague. In Indiana, the Johnson County Republicans declared that "in the present calamities of our government,

${ }^{122}$ Weber, Copperheads, 6. 
we recognize no party line but that drawn between loyalty and disloyalty-between those who sustain the government and those who oppose it." ${ }^{\prime 23}$ Despite the Peace Democrats' insistence that they remained loyal to the Union even though they did not support the war policies of President Lincoln, Republicans refused to distinguish them from Copperheads. In fact, Democratic leaders, in the spring of 1863, realized the party was unprepared for the large-scale political violence many Copperheads were encouraging. However, as historian Robert H. Churchill points out, Indiana Republican public speeches and private letters began to use "Democrat and Copperhead" interchangeably. Joining Klement, Churchill concludes that this mindset produced violence toward non-Copperhead Peace Democrats that many times bordered on the ridiculous. In Sullivan County, Indiana, Republicans assaulted a female member during church, held her down, and forcibly stripped her of a butternut pin (a badge symbolizing Southern heritage of many Democrats, not necessarily Copperheads). ${ }^{124}$

Jennifer Weber identifies three distinct phases in the Copperhead's development. The first phase began during the secession crisis. While some Copperheads supported the Confederacy, this was just a minority view. Many opposed the war but thought secession was legal as the Constitution did not expressly forbid it. What really upset them were Lincoln's actions in response to secession. As noted earlier, these Peace Democrats held extremely racists views, even more so than most nineteenth-century Americans. The

\footnotetext{
${ }^{123}$ Johnson County Republicans, quoted in Churchill, To Shake Their Guns in the Tyrant's Face: Libertarian Political Violence and the Origin of the Militia Movement (Ann Arbor: The University of Michigan Press, 2009), 111.

${ }^{124}$ Churchill, To Shake Their Guns, 112.
} 
second phase, therefore, began when Lincoln signed the Emancipation Proclamation. Copperheads were livid. They already blamed Abolitionist for the war, but now they really feared what freedmen would do to northern jobs, not to mention the virtue of northern women. The third phase began in 1864, the lowest point for the Lincoln administration. By the summer, Union armies had all but stopped on all fronts and the death toll seemed to grow by the day. Northerners who were previously supportive of the war began to demand an end to the slaughter. For a brief time, Copperheads enjoyed a spike in their ranks but as Grant started to push forward again with victories, those new peace recruits ran back to Lincoln's corner. ${ }^{125}$

By August 1864, the arrival of troops from Secretary of War Edwin Stanton forestalled the Sons of Liberty plot to liberate Confederate prisoners held at Camp Douglas. Federal agents had been watching these kinds of secret societies since 1861 and in 1864 they started to close in on the Knights of the Golden Circle. The members quickly disbanded and reorganized themselves into the Sons of Liberty. Unfortunately for them, by late summer 1864, federal agents had once again infiltrated their ranks and discovered the Chicago plot along with those involved. In the meantime, through undercover agents in Canada, arms and ammunition were found at Harrison Dodd's printing office along with correspondence from Milligan. ${ }^{126}$

Based on reports from federal agents, on October 5, 1864, Lambdin P. Milligan, along with co-conspirators Harrison H. Dodd, Horace Heffren, William A. Bowles,

\footnotetext{
${ }^{125}$ Weber, Copperheads, 6-8.

126 "Military Commission Transcript" in Klaus, The Milligan Case, 325, 332-333.
} 
Stephen Horsey, and Andrew Humphrey were arrested for conspiracy to incite insurrection and disloyal practices in the state of Indiana. Commander of the District of Indiana, General Henry B. Carrington, wanted the defendants tried in a civilian court but Indiana Governor Oliver P. Morton and Secretary of War Edwin Stanton wanted to use a more expedient method by trying the men before a military commission. Unfortunately for the government, before the trial was even convened, Dodd escaped into Canada. He was tried and found guilty in absentia by the Military Commission. ${ }^{127}$ Between October 21 and December 6, Milligan, Heffren, Bowles, Horsey, and Humphrey were tried before a military commission in Indianapolis on charges of "conspiracy against the government of the United States, affording aid and comfort to rebels against the authority of the United States, inciting insurrection, disloyal practices, and violation of the laws of war." The specific charge for the violation of the laws of war "consisted of an attempt, through a secret organization, to give aid and comfort to rebels." ${ }^{128}$ This was, of course, in reference to their plan to liberate the prisoner of war camp and arm Confederate soldiers. ${ }^{129}$

This conspiracy was first formulated in the summer of 1864. According to testimony, the plan was to seize the federal arsenals in Columbus, Ohio, Indianapolis,

127 "Military Commission Transcript" in Klaus, 250.

${ }^{128}$ Ex parte Milligan, 71 U.S. 2 (1866).

${ }^{129}$ If Milligan and his co-defendants had been tried in a civilian court, the charge would have most likely been authorized under Section 5331 of the Revised Statutes. "Every person owing allegiance to the United States who levies war against them, or adheres to their enemies, giving them aid and comfort within the United States or elsewhere, is guilty of treason.” Rev. Stat., Sec. 5334 (July 1862). By charging them with violating the laws of war then, the Military Commission considered the defendants enemy belligerents. 
Indiana, and Chicago, Alton, and Rock Island, Illinois and free Confederate soldiers imprisoned in those states. The Confederate soldiers, alongside groups of Copperheads, would then overthrow each of these states' governments and establish provisional governments. The starting point of the uprising was planned for the Democratic National Convention. Clement Vallandigham would make such an inflammatory speech at the Convention that the Democrats of Chicago would rise up and assist the armed men of the Sons of Liberty in liberating the Confederate soldiers. The Sons of Liberty were a Copperhead group formed in 1864 that operated in Illinois, Indiana, Kentucky, and Missouri. Essentially, the goal was to draw Sherman northward and away from the South which would presumably result in some form of negotiation settlement whereby the South would keep their slaves and the "Union as it was" would be restored. However, federal agents had infiltrated the Sons of Liberty and uncovered the plot. By August $20^{\text {th }}$, Indiana Governor Morton discovered that arms had been shipped to Harrison H. Dodd in Indianapolis. Dodd's office was searched and the arms and various incriminating letters were seized. ${ }^{130}$

When the Democratic National Convention convened in Chicago, the city's Republican newspapers announced the presence of large numbers of Sons of Liberty. Federal agents kept watch over the city and reinforcements stood guard at the prisoner of war camp, Camp Douglas. The Convention ignored Vallandigham and nominated George B. McClellan instead. With the plot falling apart before their eyes, the leaders of the Sons of Liberty stood down from their revolt. A few days after the Convention

${ }^{130}$ Towne, Surveillance and Spies in the Civil War, 256-264. 
ended, Dodd, Grand Commander of the Sons of Liberty in Indiana, was arrested.

Bowles, Milligan, Horsey, Humphreys, and Heffren were arrested soon thereafter. ${ }^{131}$

The Military Commission convened on October 21, 1864 in the United States Court House in Indianapolis. The detail for the Commission was comprised of thirteen senior military officers, of which six were in command of Indiana volunteer regiments. Each defendant was permitted to retain his own counsel. Joseph E. McDonald and John R. Coffroth were engaged to represent Milligan and Horsey. McDonald was a former Democratic Congressman and State's Attorney from Indiana. He had also defeated Milligan in the Democratic nomination for Governor in $1864 .{ }^{132}$ Coffroth was an old friend of Milligan and fellow Peace Democrat. Indianapolis Republican attorney Jonathan W. Gordon was appointed to represent Humphreys, Bowles, and Heffren. ${ }^{133}$

Once the attorneys for the accused were approved by the Commission, the defendants objected to the Commission's jurisdiction on the basis that they were all United States citizens and thus entitled to be tried in a civil court. After deliberation, the Commission ruled that the question of jurisdiction would be determined at the conclusion of the trial. ${ }^{134}$ J.W. Gordon, attorney for Humphreys, Bowles, and Heffren, made a motion for separate trials of the accused. He reasoned, "We put this plea on the discretion of this Court, as governed by the common law, believing that these defendants have interests that cannot be sub-served by trying them together, and as a matter of

\footnotetext{
${ }^{131}$ Ibid., 266-267.

${ }^{132}$ Fairman, History of the Supreme Court of the United States, 196.

133 Towne, The Persistent Nullifier, 321.

134 “Military Commission Transcript," Klaus, 251-253.
} 
justice I ask the Court for their severance on trial."135 Again, after deliberation, the Commission determined that no rights of the accused would be prejudiced by a joint trial.

When it came to trying civilians before military commissions during the Civil War, there were no special procedures. The commission that tried Milligan and his codefendants followed the same rules of court-martials that tried soldiers. Military commissions drew their authority from the commanding general. ${ }^{136}$ Essentially, the general had unilateral power to select members of the commission from among his own officers. The defendant was able to challenge the members and attempt to discredit their objectivity, but the commission members themselves were the ones to rule on such objections. The commission members, consisting of at least five officers, also decided the outcome of the case, the sentence, and procedural objections. ${ }^{137}$ The Judge Advocate played the role of both prosecutor and judge. As judge, he was often asked to deliver to the commission legal opinions as objections or questions of law were raised. ${ }^{138}$ Military commission procedures did have some advantages over civilian courts from the perspective of the defendant. A complete trial transcript was kept, which was not the case in most civilian courts at the time. ${ }^{139}$ Therefore, the reviewing body had a record

135 Ibid.

${ }^{136}$ Francis Lieber, Instructions for the Government of Armies of the United States in the Field (New York: D. Van Nostrand, 1863). 1974), 27.

${ }^{137}$ Joseph W. Bishop, Justice Under Fire: A Study of Military Law (New York: Charterhouse,

${ }^{138}$ William P. Craighill, The Army Officers Pocket Companion for Staff Officers in the Field (New York: D. Van Nostrand, 1862), 270.

139 The 1863 Laws of War (Washington: War Department, 1863), 154. 
from which they could refer to thus providing a more judicious assessment of the defendant's case.

The origins of military commissions in America extend back to the early days of the country itself. In June of 1775, as the American Revolution began to escalate, the Continental Congress adopted 69 Articles of War, drawn largely from the British Articles of War. ${ }^{140}$ These Articles of War were administered exclusively by the legislature and framed the procedures for courts-martial of soldiers, not civilians. ${ }^{141}$ A court-martial is not a military commission however. A court-martial is used to apply military law to members of the U.S. military. A military commission applies the laws of war and is used to try unlawful enemy combatants or enemy combatants who are charged with violations of the laws of war. In 1787, Samuel Carter, a citizen of New Jersey, was arrested for delivering arms to the British. General George Washington immediately ordered Carter to be transferred to a New Jersey civilian court stating, "[I am] not fully satisfied of the legality of trying an inhabitant of any State by Military Law, when the Civil authority of that State has made provisions for the punishment of persons taking Arms with the Enemy."142 Despite being seventy-nine years apart, Washington's analysis somewhat mirrors Davis's analysis on the constitutionality of military trials of civilians.

${ }^{140}$ Louis Fisher, Military Tribunals \& Presidential Power: American Revolution to the War on Terrorism (Lawrence, Kansas: The University Press of Kansas, 2005$), 7$.

${ }^{141}$ Fisher, Military Tribunals \& Presidential Power, 9.

${ }^{142}$ Ibid., 10. It is important to note that this was prior to ratification, so the United States Constitution along with its Commander-in-Chief clause did not yet exist. Therefore, in using it as precedent, Fisher may be going out on a limb. 
Constitutional scholar Louis Fisher notes that with the ratification of the United States Constitution in 1787 and the subsequent creation of a new American government, military power stemmed from legislative authority as it did during the war. Pursuant to the Constitution, the President was made Commander-in-Chief of the army and navy but at the same time was made accountable and subordinate to civilian law. Under Section 8 of Article I of the Constitution, it was Congress who was given the power "To define and punish Piracies and Felonies committed on the high Seas and Offenses against the Law of Nations" and "To make Rules for the Government and Regulation of the land and naval Forces." As we have seen, this was not Lincoln's view at all. Again, he believed that his authority as Commander-in-Chief stemmed from international law and the state of rebellion that existed during the Civil War.

In 1789, legislation was passed that essentially adopted the Articles of War that had been used during the Revolutionary War. In pertinent part, they stated that military troops, "shall be governed by the rules and articles of war which have been established by the United States in Congress assembled."143 In April 1806, Congress enacted a bill that consisted of 101 Articles of War, many of which, like the previous Articles of War, set forth the rules and procedures for courts-martial. However, language was added to address spies. Specifically, "all persons not citizens of, or owing allegiance to the United States of America, who shall be found lurking as spies...shall suffer death...by sentence

${ }^{143}$ An Act to recognize and adapt to the Constitution of the United States, the establishment of the troops raised under the resolves of the United States, in Congress assembled, U.S. Statutes at Large 96 (1789). 
of a general court marital." ${ }^{144}$ During the Civil War, this same language would be incorporated into the Habeas Corpus Act of 1863, which provided for the trial of civilians by military commissions.

One of the first instances in which military commissions were used to try civilians was during the War of 1812 when General Andrew Jackson declared martial law throughout the city of New Orleans. ${ }^{145}$ After the British were defeated Jackson maintained the state of martial law. Louis Louallier, a New Orleans resident, wrote an article in a local newspaper declaring that citizens accused of a crime should be tried before a civil court, not a military tribunal, and stated that Jackson's order was "no longer compatible with our dignity and our oath of making the Constitution respected." On March 5, 1815, General Jackson had Louallier arrested for inciting mutiny and disaffection within the army. However, when Federal District Judge Dominick Hall granted a writ of habeas corpus for Louallier, Jackson arrested the Judge as well. Jackson was later fined $\$ 1,000$ for his actions by Judge Hall himself. ${ }^{146}$ Long before the civil liberties issues of the Civil War, we see an emerging argument over the use of military commissions.

Military commissions were once again used to try civilians during the Mexican American War. When American soldiers invaded Mexico, they did not have a stable

\footnotetext{
${ }^{144}$ An Act for Establishing Rules and Articles for the Government of the Armies of the United States, U.S. Statutes at Large 371 (1806).

${ }^{145}$ It is interesting to note, if Copperheads during the American Civil War saw Jackson as a model for limited federal government and "strict constructionism", they seemed to have forgotten or ignored Jackson's actions in New Orleans.

${ }^{146}$ Fisher, "Military Tribunals: Historical Patterns and Lessons," 5-8.
} 
legal system to prosecute those who violated the law of war. Therefore, General Winfield Scott declared a state of martial law in Mexico for both American soldiers and Mexican citizens. However, when Secretary of War William Marcy submitted a bill to authorize these military tribunals, Congress refused to consider it. In circumnavigating the lack of Congressional authority, Scott issued General Orders No. 20 on February 19, 1847. This order defined specific crimes committed by civilians and American soldiers and declared that those crimes would be tried before military commissions. Scott never did receive Congressional permission for his military commissions and after the war the Supreme Court overturned many of Scott's actions and the actions of other officers who ordered military trials of civilians. ${ }^{147}$

In Jecker v. Montgomery (1852), the Supreme Court ruled that under the Constitution, judicial power is vested in the Supreme Court and in such inferior courts as Congress shall establish. Neither the executive nor any of its military officers could establish a court in a conquered country. In a unanimous decision, written by Justice Taney, the Court stated that military commissions established in Mexico "were nothing more than the agents of military power" and "were not courts of the United States, and had no right to adjudicate." ${ }^{\prime 14}$ These early legal challenges to military commissions did not yet revolve around civil liberties however. Instead they relied on the usurpation of executive power. It would take civil libertarian-minded jurists, like David Davis, to bring

\footnotetext{
${ }^{147}$ Ibid., 11-14.

${ }^{148}$ Jecker v. Montgomery, 13 How. (54 U.S.) 498, 515 (1852).
} 
constitutional liberalism to the forefront of the law in order to establish a conversation about civil liberties during wartime.

The most expansive use of military commissions, however, occurred not in a foreign country, but rather on domestic soil during the American Civil War. It was during this four year domestic rebellion when civil liberties issues would appear on a grand scale. These Civil War-era military commissions were not initially established by Congress but rather by President Lincoln and his field commanders. In many situations, particularly in the Border States, the loyalty of civil courts was deemed questionable. Military law therefore, replaced civilian law to ensure offenses such as resisting the draft, disloyal speech, and the overthrow of state government would be adequately dealt with. After declaring martial law and establishing military commissions in areas such as Missouri and Maryland, President Lincoln convinced Congress to recognize and approve, retroactively, his Presidential acts. In 1863, one particular piece of legislation declared "all persons...found lurking as spies...shall be triable by a general court-martial or military commission."149 Many federal judges during the war, like Taney and Perkins, attempted to maintain their authority to uphold the rule of law but were either curtailed or simply ignored by military officials. ${ }^{150}$ It was on this legal battleground where Milligan was taken from the ordinary course of civilian law and tried before a military commission.

${ }^{149}$ An Act relating to Habeas Corpus, and regulating Judicial Proceedings in Certain Cases, U.S. Statutes as Large, 755 (1863).

${ }^{150}$ Fisher, "Military Tribunals: Historical Patterns and Lessons," 16-20. 
The treason trial of Milligan and his co-defendants reconvened on October 22, 1864. In addition to reserving the question of the Military Commission's jurisdiction until after the trial, during the examination of William M. Harrison on October 22, a Sons of Liberty pamphlet entitled, "Proceedings of the Grand Council of the State of Indiana," was entered into evidence by the Judge Advocate before the defense had an opportunity to examine and challenge it. Harrison's attorney objected stating, "In all courts of justice, before a document can be offered into evidence, all these distinct facts as to its identity are gone into and proved. And when a document has once gone into evidence, we cannot object to it. If it goes in evidence on insufficient identity, how are we to remedy it?" ${ }^{151}$ In other words, proper procedure under the common law dictated that the defense have the opportunity to review the evidence and to object to it. The Commission, however, overruled the objection and the pamphlet was let into evidence. This was not a common law court.

The Military Commission also accepted into evidence one particular speech Milligan made in August 1864, in Fort Wayne, Indiana. W.L. Bush, a reporter for the Cincinnati Gazette, testified as to the content of this speech.

Q: State to the court what was said by Mr. Milligan on the state of the country, whether it was prosperous or otherwise?

A: He referred to the country as desolated by this war, and the oppressions of the Administration. That was the general tenor of his remarks on that point. Q: What did he state in reference to the freedom of the press and of speech?

${ }^{151}$ Klaus, The Milligan Case, 264. 
A: He spoke of the freedom of speech allowed as simply that granted by a Lincoln mob-as a freedom in name rather that in fact.

Q: What did he say in reference to the draft or conscription?

A: He stated, if the war was right, the draft was right, and if they considered the war right, and were good citizens, they would not grumble about the draft.

Q: What else did he say about the rightfulness of the war?

A: He denied the war was right, and proceeded to argue, that under the Constitution the President had no power to coerce a State.

Q: What did he say about the President of the United

States?

A: He spoke of him as a tyrant, and an usurper, I think.

Q: Did he denounce arbitrary arrests?

A: I think he did.

No direct evidence was ever introduced that Milligan did anything other than oppose the war and vehemently criticize the Lincoln administration. Yet, the Military Commission interpreted his speech to be treasonous and disloyal. Milligan's attorney, on the other hand, argued his client was simply being punished for criticizing a Republican administration's prosecution of a war he did not believe in. Testimony concluded and closing arguments were presented on December 6. After deliberation, the Commission found the defendants guilty and sentenced Milligan, Bowles, and Horsey to death and Humphreys to hard labor for life. ${ }^{152}$

While waiting for his execution, Milligan sent a letter to his long-time friend, Edwin Stanton, pleading for his intervention. "I have been condemned to die without evidence," he wrote, "please examine the facts and advise the President do this much for

${ }^{152}$ Ibid., 331-338, 455-457. 
an old acquaintance and friend."153 There is no evidence that Stanton replied. At the same time, Milligan's attorney, Joseph McDonald, who had practiced on the Illinois circuit with Lincoln, traveled to Washington to personally request clemency for his client. McDonald recorded his meeting with the President:

He went over the history of my client's crimes as shown by the papers in this case, and suggested certain errors and imperfections in the record. The papers, he said, would have to be returned for correction, and that would consume no little time. "You may go home, Mr. McDonald," he said, with a pleased expression. "And I'll send for you when the papers get back; but I apprehend and hope there will be such a jubilee over yonder," he added, pointing to the hills of Virginia just across the river, "we shall none of us want any more killing done."154

We, of course, cannot say for certain what Lincoln's final decision would have been. He was assassinated before the corrected papers could be returned. However, his comments about no more killing suggests that he was planning to either commute Milligan's sentence or release him. Unfortunately, Lincoln's assassination at the hand of a Southerner ruined any hope of mercy for both the defendants and the South as a whole. Caught up in the disquiet after Lincoln's assassination, President Johnson vowed to "make treason odious." 155 He ordered the execution of Milligan and his co-conspirators

${ }^{153}$ Lamdin Milligan to Secretary of War Edwin M. Stanton, December 28, 1864 quoted in Towne, "The Persistent Nullifier," 337.

${ }^{154}$ Joseph McDonald, quoted in Dean Sprague, Freedom Under Lincoln (Boston: Houghton Mifflin, 1965), 289-290.

${ }^{155}$ Fairman, History of the Supreme Court, 197. 
to be carried out on May 19, 1865, six days after he himself authorized the military trial of those implicated in Lincoln's assassination. ${ }^{156}$

In a last-ditch effort, Milligan's lawyer sued for a writ of habeas corpus in the federal circuit court in Indianapolis where David Davis sat on circuit duty. Meanwhile, other attorneys and Milligan's wife pleaded with President Johnson to commute Milligan's sentence to life in prison. ${ }^{157}$ Justice David Davis intervened as well by traveling to Indianapolis to speak with Governor Morton, who had been one of the leading voices in trying Milligan before a military commission in the first place. During a Sunday afternoon ride, Davis attempted to convince Morton that the Military Commission had been illegal since the civilian courts in Indiana had been open and functioning and that martial law had not been declared in the state. Morton was convinced to save Milligan's life. The Governor reasoned that if the defendants had been convicted unlawfully, he did not want to be responsible for it. He immediately wrote to Johnson advising him to commute their sentences. ${ }^{158}$ This visit to Morton was the first of many steps Davis took to directly intervene on Milligan's behalf.

On May 10, 1865, Milligan's Petition for Habeas Corpus was filed with the Circuit Court of the United States for the District of Indiana. It was heard the next day by Judge David Davis, the Circuit Justice, and David McDonald, the District Judge. Procedurally, a divided decision on the writ meant that the case would be elevated to the United States Supreme Court. The next day, the two judges wrote a letter to President

\footnotetext{
${ }^{156}$ Brian McGinty, Lincoln \& The Court (Cambridge: Harvard University Press, 2008), 249.

157 Towne, "The Persistent Nullifier," 338.

${ }^{158}$ Klaus, The Milligan Case, 40.
} 
Johnson stating, "We beg leave also most respectfully to state that, aside from the legal question, which we press most earnestly, we doubt the policy of the proposed execution. We fear its effect upon the public mind in Indiana. By many, these men will be regarded as political martyrs." ${ }^{\prime 159}$ By today's standards this would seem to be extremely inappropriate. It should be noted that the judges started the letter by stipulating to the defendants' guilt and that their primary concern was that the Military Commission was "unknown to Common Law." ${ }^{160}$ Procedurally then, they asked Johnson to delay the execution until the defendants had an opportunity to appeal their case to the Supreme Court. While this letter seems to point to Davis's political considerations concerning military commissions, this strategy was most likely used to convince Johnson of the political ramifications of executing the defendants in a state full of Peace Democrats. For Davis though, proper legal procedures and civil liberties remained first and foremost.

While a Republican, Davis shared many of the political principles of Northern Democrats regarding emancipation. In fact, throughout the war, Davis constantly advised Lincoln on the dangers of waging a war against slavery. Illinois Republican Senator Orville Browning wrote in his diary on January 19, 1863: "In conversation with Judge Davis of the Supreme Court this morning he told me that he had a conversation with the President yesterday in which he represented to him the alarming condition of things, and urged upon him to reconstruct his cabinet, and change his [emancipation] policy, as the only means of saving the Country. The President told him that this proclamation in regard

${ }^{159}$ Davis and McDonald to President Johnson quoted in Fairman, History of the Supreme Court, 198. ${ }^{160}$ Ibid., 198. 
to slavery was a fixed thing-that he intended to adhere to it, and whether he changed his cabinet must be determined by future events." 161 Davis's advice to Lincoln to reverse course on emancipation could be construed as evidence that his intent in Milligan was to restrict black rights during Reconstruction South by returning judicial power to local civilian courts including courts in the South. As explored in the last chapter, Davis was not as progressive as Lincoln on issues of slavery and race.

Up until this point and as we will see in his majority opinion, Davis was simply concerned with military commissions in the North. More importantly, though, it is apparent that Davis went out of his way to ensure that Milligan's case would reach the Supreme Court, so that Radical Republican-backed military tribunals in the North, and thus Republican partisanship, could be finally scrutinized before the highest court in the land.

Following the request of Davis and McDonald, President Johnson initially would not even review Milligan's case. Johnson stated, “The very fact of the prisoner resorting to the court upon a technical question of jurisdiction is a confession of guilt."162 Without leaving any reason for his change of mind, Johnson considered Davis and McDonald's plea and on May 30, 1865, commuted all the sentences to life in prison.

Even if Johnson had not commuted Milligan to life in prison, the habeas corpus petition itself conformed to the Habeas Corpus Act of 1863 in that a grand jury had convened since Milligan's arrest and submitted no indictment against him. According to

${ }^{161}$ Browning, The Diary of Orville Hickman Browning, 616.

162 Klaus, The Milligan Case, 41. 
the Act, therefore, Milligan should have been released from military custody. However, if Davis and McDonald had issued the writ, they knew the military would simply disregard it, as it had done so throughout the war. In fact, General Hovey was under strict orders to ignore any habeas corpus writ issued by a civilian court. Therefore, after hearing the petition, Davis and McDonald certified that they differed in opinion, thus placing the case in the hands of the United States Supreme Court in accordance with appellate procedure. ${ }^{163}$

Arguments before the Supreme Court were heard from March $5^{\text {th }}$ to March $13^{\text {th }}$ 1866, two months after the adoption of the Fourteenth Amendment, and at the same time when the continuance of military rule in the South was being debated in the chambers of Congress. For the government stood former General Benjamin Butler, Attorney General James Speed, and Ohio attorney Henry Stanbery. The Petitioners were represented by future U.S. President James A. Garfield, Jeremiah Black, and David Dudley Field, older brother of Justice Stephen J. Field. Attorneys with cases before the Supreme Court were usually only permitted two hours to argue. Three hours of argument were allotted for each attorney in Milligan. At this time, the Supreme Court relied more on oral argument than written briefs. ${ }^{164}$ The additional hour given to counsel may point to the possibility that the members of the Court understood the importance of the case before them and therefore wanted to give extra attention to both sides. It is also important to note that in addition to arguing against expanded presidential war powers and martial law in order to

${ }^{163}$ Fairman, History of the Supreme Court, 200.

${ }^{164}$ Rehnquist, All the Laws but One, 118. 
discredit the Military Commission's jurisdiction, counsel for Milligan also used the same civil libertarian language that Judges Perkins and Davis had been using throughout the war. In fact, many of the civil liberty arguments advanced by Milligan's attorneys would be incorporated into Davis's own majority opinion. A more detailed analysis of this opinion will be covered in the next chapter.

Henry Stanbery opened for the government, narrowing his remarks to the question of jurisdiction. Benjamin Butler would argue on the merits. Stanbery argued that the Supreme Court did not possess jurisdiction to review the case of Lambdin Milligan under the Act of 1802, which prohibited the Supreme Court from hearing ex parte cases. He stated, "All the cases before this court, during all the time that this jurisdiction has existed, are cases between parties, and stated in the usual formula A. $v$. B...all the rules of this court exclude the idea of an ex parte case under the head of appellate jurisdiction." ${ }^{165}$ The Judiciary Act of 1802 read:

That whenever any question shall occur before a circuit court, upon which the opinions of the judges shall be opposed, the point upon which the disagreement shall happen, shall, during the same term, upon the request of either party, or their counsel, be stated under the direction of the judges, and certified under the seal of the court, to the supreme court ${ }^{166}$

\footnotetext{
${ }^{165}$ Henry Stanbery, "Argument in the Supreme Court of the United States on the Side of the United States," quoted in Klaus, The Milligan Case, 86.

${ }^{166}$ An Act to amend the Judicial System of the United States, U.S. Statutes at Large 156 (1802).
} 
For Stanbery, the language "upon the request of either party" intimated a cause of action between two parties but since Davis and McDonald had only acted on behalf of Milligan the situation did not meet the two party standard under the Act of $1802 .{ }^{167}$

But then Stanbery made what may be considered a blunder. Misreading and misapplying an old Latin dictum, he argued "conventional and legislative laws and enactments are silent amidst arms, and when the safety of the people becomes the supreme law." ${ }^{168}$ Here, we see perhaps the most radical expression of the necessity argument that Lincoln had taken as commander-in-chief. To be clear, at this point Lincoln had been assassinated and never made this argument. Stanbery argued that the very nature of a domestic insurrection necessitated the expansion of presidential war powers beyond legal constitutional limits. (Lincoln himself believed that presidential war powers expanded, but within the Constitution by way of the commander-in-chief clause and only within the limits of international law or the laws of war.) Furthermore, Stanbery relied heavily on Lincoln's habeas corpus proclamation of 1862 which provided for the military trial of civilians. ${ }^{169}$

Attorney General James Speed then argued on the merits of the case. Butler would later rejoin. Military commissions, according to Speed, established their authority from martial law and that it was therefore only by military law that commission

${ }^{167}$ Stanbery quoted in Klaus, 88.

${ }^{168}$ Stanbery quoted in Klaus, 91.

${ }^{169}$ Stanbery quoted in Klaus, 93. 
proceedings could have been reviewed. He then explained why military commissions were vital to times of war.

It would be impossible for the commanding general of an army to investigate each fact which might be supposed to interfere with his movements, endanger his safety, aid his enemy, or bring disorder and crime into the community under his charge. He, therefore, must commit to his officers, and in practice, to a board of officers, as a tribunal, the charge of examining the circumstances and reporting the facts in each particular case. ${ }^{170}$

Here, Speed made an exegesis of war argument. Because a commander in the field does not have time to examine the dangers posed to his army by civilian populations under martial law, military commissions must conduct such investigations for the safety of the military force.

Speed also made the argument that the President as Commander-in-Chief is not constrained by the Constitution. He stated that when Lincoln suspended habeas corpus during the war, it "was an exercise of his sovereignty in carrying on war" and that "his powers must be without limit. New difficulties [during war] are constantly arising, and new combinations are at once to be thwarted, which the slow movement of legislative action cannot meet." 171 In other words, according to Speed, Congress is wholly incapable of keeping up with the ever-evolving nature of war and making decisions regarding those

\footnotetext{
${ }^{170}$ James Speed, “Argument of James Speed for the United States," quoted in Klaus, 100.

${ }^{171}$ Speed, quoted in Klaus, 105.
} 
events. Following Speed's logic then, the President is the only one who could make such time sensitive decisions.

In regards to the $4^{\text {th }}, 5^{\text {th }}$, and $6^{\text {th }}$ Amendments, Speed contended that "these, in truth, are all peace provisions of the Constitution and, like all other conventional and legislative laws and enactments, are silent amidst arms, and when the safety of the people becomes the supreme law." ${ }^{172}$ Essentially, Speed was forwarding the argument that there were no limitations on the war-making and war-conducting powers of Congress or the President. This outlandish idea did not go over well with the Court. Justice Miller, in a private letter, said that "the session of the Court has developed his utter want of ability as lawyer-He is certainly one of the feeblest men who has addressed the Court this term." 173 Butler's performance at the end of oral argument would not be any more convincing.

The case for the Petitioners was initiated by Republican James Garfield. He opened with a breadth of both English and American legal history. In response to Stanbery, Garfield argued, "The only ground on which the learned counsel attempts to establish the authority of the military commission to try these petitioners is that of the necessity of the case. I answer, there was no such necessity."174 For Garfield, then, necessity was simply a matter of geography.

But what is the nature of that necessity. If, at this moment, Lee, with his rebel army at one end of Pennsylvania Avenue, and Grant with his army of the

172 Speed, quoted in Klaus, 106.

${ }^{173}$ Samuel Miller to Thomas Ewing, March 4, 1866, quoted in Charles Fairman, Mr. Justice Miller and the Supreme Court (Cambridge: Harvard University Press, 1939), 118.

174 James Abram Garfield, "Argument of James Abram Garfield for the Petitioner," quoted in Klaus, The Milligan Case, 114. 
Union at the other...were approaching this Capitol...I

have no doubt they would expel Your Honors from the bench. The jurisdiction of battle would supersede the jurisdiction of law. This court would be silenced by the thunders of war. It has been fully settled that those states constituted a belligerent government de facto, against which the federal government might extend absolute military jurisdiction over every foot of rebel territory. ${ }^{175}$

It should be noted that "necessity" was not just a catchphrase used by Lincoln and his military commanders in the field. Rather it was the rationale for the entire laws of war and of the Emancipation Proclamation. Garfield was drawing the line of necessity in a geographical sense. He also admitted that there were times in which civilian law was silent. "But the military jurisdiction does not extend beyond the territory of the rebellious states, expect where the tide of war actually sweeps beyond the limits and makes it impossible for the civil courts to exercise their functions." 176 During the drafting of his majority opinion, Davis would take the same geographical standard for necessity.

Garfield clarified his position by stating to the Court that he did not want a decision that would restrict Congressional authority in Reconstruction South. Having no such necessity in the North, argued Garfield, Milligan should have been charged under criminal law, not military law. On the issue of whether the Constitution was "silent" during the war, Garfield pronounced, "Such a doctrine...is too monstrous to be tolerated for a moment. The just and final settlement of this great question will take a high place among the great achievements which have immortalized this decade. It will establish

\footnotetext{
175 Garfield quoted in Klaus, 116.

${ }^{176}$ Garfield quoted in Klaus, 117.
} 
forever this truth, that a republic can wield the vast enginery [sic] of war without breaking down the safeguards of liberty." "177 In other words, contrary to Stanbery's argument, the abrogation of civil liberties should not be the absolute rule in times of war. In fact, his argument would closely follow Davis's majority opinion, in that he supported military commissions in certain cases, that of those in the South where an actual state of war existed. Davis would also go on to follow Garfield's defense of the Bill of Rights in that, "the Constitution and the laws of the United States have carefully provided for the protection of individual liberty and the right of accused persons to a speedy trial before a tribunal established and regulated by law."178 Here we see the emergence of constitutional liberalism in which the law is centering on individual liberties.

Democrat Jeremiah Black, former Chief Justice of the Pennsylvania Supreme Court, Attorney General, and Secretary of State under Buchanan addressed the Court next. Black explained that the "strange tribunal" under which his clients were tried possessed neither the jurisdiction to convict them or even hear the case itself. He explained by referencing the Habeas Corpus Act of 1863, "which was passed with express reference to persons precisely in the situation of these men, declares that they shall be delivered up for trial to the proper civil authorities." 179 According to this act, if an individual was being detained by an executive order and was not indicted by a grand

177 Garfield quoted in Klaus, 119.

178 Garfield quoted in Klaus, 125.

${ }^{179}$ Jeremiah S. Black, "Argument of Jeremiah S. Black for the Petitioner," quoted in Klaus, The Milligan Case, 123. 
jury, he was to be released. Black pointed out that Milligan had not been indicted by a grand jury and was therefore held illegally by military authorities.

After the Habeas Corpus Act of 1863 was passed on September 15, Republicans were more at ease about Lincoln's actions. Now there was legislative authority to suspend the privilege of the writ of habeas corpus. In short, by this act, Congress had endorse the president's earlier unilateral suspensions. Yet, civil liberties issues continued to be debated among Democrats. They commented on the Habeas Corpus Act of 1863 saying, "his own party admitted his usurpation long afterward, and after hundreds of like cases had occurred, by passing an act of Congress to save him from the consequences of his arbitrary use of power." ${ }^{\prime 80}$ Ironically, the act was now being used by a Democratic attorney to defend a Peace Democrat who had publically denounced Lincoln.

Moving up from statutory construction to constitutional law, Black also argued that Indiana was not in a theatre of war when Milligan was arrested and "the courts were wide open, where judicial process was executed every day without interruption, and where all the civil authorities, both State and National, were in full exercise of their functions." 181 According to Black, Milligan should not have been tried by a military commission because under the suspension clause suspension was only allowed in time of actual invasion or rebellion. To this he tacitly added, in the location of actual invasion or rebellion as well. Davis would reach the same conclusion in his majority opinion and

${ }^{180}$ Mark Neely, The Fate of Liberty, 202-203.

${ }^{181}$ Black quoted in Klaus, 122. 
conclusively declare that military commissions in the North were illegal where the civilian courts were open and functioning.

Scholars such as Stephen Towne have argued that evidence suggests that "political leaders chose not to try the conspirators in civilian courts speaks to their lack of faith in the judicial process at a time of national emergency rather than the lack of evidence of conspiracy." ${ }^{\prime 182}$ For Towne, Copperheads did in fact possess a threat to the Midwest and the war in general. In accordance with his client's best interests, it seems Black implied the Copperhead movement was not a serious threat to the war effort and that therefore there was not a real invasion or rebellion. Agreeing with Black, Davis would declare that Indiana was not in a state of war and thus Milligan should have been turned over to a civilian court.

During Reconstruction, this theatre of war argument would resurface. Despite Davis's opinion in Milligan, military trials of civilians continued. However, from July 1867 to March 1877, the southern states were technically under martial law by virtue of congressionally created military districts, thus justifying the continuation of military commissions. Radical Republicans who set up these military districts and tribunals understood that they were necessary to protect freedmen from an all-white southern judicial system but Davis's majority opinion seemingly put them back into place. As we will see though, Davis's opinion was not intended to prohibit military commissions in the Reconstruction South as Radical Republicans thought.

182 Towne, Surveillance and Spies in the Civil War, 308. 
Black, like Garfield, also invoked the $6^{\text {th }}$ Amendment of the Bill of Rights in defense of Milligan:

[W] hen they [founding fathers] came to frame a government for themselves and their posterity, had failed to insert a provision making the trial by jury perpetual and universal, they would have proved themselves recreant to the principles of that liberty of which they professed to be the special champions. ${ }^{183}$

Black was arguing that the founders understood that citizens in a democracy could not be ruled by a government that punished without restraint. Furthermore, "[t]hey went over Magna Charta, the Petition of Right, the Bill of Rights, and the rules of the common law, and whatever was found there to favor individual liberty they carefully inserted in their own system." 184 Davis would take the same "strict constructionist" view, in that the Constitution applies both in war and in peace. As Robert H. Churchill explains in To Shake Their Guns in the Tyrant's Face: Libertarian Political Violence and the Origins of the Militia Movement, "strict construction" in this context reflects an Antifederalist rather than a Federalist understanding of proper constitutional construction. This makes sense in light of Copperhead support of state's rights and Davis's defense of Peace Democrats' civil liberties during the war.

David Dudley Field, brother of Justice Stephen J. Field, closed the case for the Petitioners by stating that the authority of Congress to establish martial law should not

${ }^{183}$ Black quoted in Klaus, 126.
${ }^{184}$ Black quoted in Klaus, 127. 
have been an issue since Congress had not established martial law at all. "The source and origin of the power to establish military commissions, if it exists at all, is in the assumed power to declare what is called martial law. I say what is called martial law; for, strictly there is no such thing as martial law; it is martial rule." ${ }^{185}$ Field went on to explain what he meant by martial law as being no law at all. For Field, a liberal advocate of legal codification and opponent of judge-made common law, the abolition of civil law could only mean replacing civil law with the will of the military commander. The laws of war were to diffuse and uncodified to have much meaning for him. In other words, by extension of executive power, the president, had the power during a time of war to suspend the Constitution and the laws of the nation and put himself in their place. Lincoln had eventually come to adopt the international law position that as commanderin-chief he was restrained by the laws of war during the war. Field was arguing against this. For Field, martial law was tantamount to a dictatorship, which had no authority in the U.S. Constitution. At stake in Ex parte Milligan was whether uncodified international law rooted in precedent and legal treatise would have a place in American jurisprudence or whether constitutional liberalism and the Bill of Rights would reign supreme for civil liberties even during wartime.

Like his co-counsel, Field defended the Bill of Rights over international law, specifically the $5^{\text {th }}$ Amendment. Field stated that it was "made for a state of war as well as a state of peace; it was aimed at the military authority, as well as the civil; and it was

${ }^{185}$ David Dudley Field, “Argument of David Dudley Field for the Petitioner," quoted in Klaus, The Milligan Case, 78. 
as explicit as our mother tongue could make them." 186 Again, this was almost verbatim what Davis would write in his majority opinion when he wrote that the Constitution is a law for rulers and people, in times of war and peace. ${ }^{187}$ It seems that while Davis intervened in several civil liberties cases throughout the war, these other constitutional liberal-minded attorneys began to contemplate the theoretical framework for constitutional liberalism. Davis did not leave behind any writings that explained his state of mind during oral argument or the drafting process, but it seems to be the case that Field, Black, and Garfield helped Davis conceptualize the civil liberties issues that he had already been fighting for. In other words, by creating a national military power and thus putting a federal police power in the North had created the need for limits on that very power. This in turn gave liberals like Field a chance to nudge common law judges like Davis away from the quaint world of precedent and legal treatise and into the modern world of legal liberalism.

Benjamin Butler replied for the government. As a general during the war, Butler had declared martial law on New Orleans and tried numerous civilians by military commissions. He too expounded on a plethora of precedents, including the famous 1864 case Ex parte Vallandigham in which the Supreme Court ruled that it had no authority to

${ }^{186}$ Field quoted in Klaus, 80.

187 John Fabian Witt in Lincoln's Code: The Laws of War in American History, notes that the Constitution was actually originally rooted in international law. In the 1814 Supreme Court case Brown v. United States concerning property confiscation, Justice John Marshall stated, "'The Constitution of the United States' had been written when a new and gentler law of war characterized by 'moderation and humanity' had come to be 'received throughout the civilized world." John Fabian Witt, Lincoln's Code: The Laws of War in American History (New York: Free Press, 2012), 70-71. Therefore, the move toward liberal constitutionalism with an emphasis on the Bill of Rights was highly ironic in the extreme. Also ironic, was the fact that Copperheads and Southern Democrats before them used this same argument, mostly to protect their interest in slaves from Federal government interference. 
review the Military Commission that convicted Congressman Vallandigham since the Military Commission was not considered a court under the Judicial Act of 1789.

According to Butler, it followed that the Court had no authority to review Milligan's case either.

Butler was wrong in his analysis however. In Vallandigham, the Court did not have authority to review appeals directly from a military commission. In Milligan, however, the appeal came from Davis and McDonald's federal circuit court on a habeas corpus petition. The Supreme Court did have authority to review appeals directly from lower federal courts. Butler also addressed the president's powers under martial law. Quoting from Brown v. The United States (1814), Butler stated, "The sovereignty, as to declaring war and limiting its effects, rests with the legislature. The sovereignty as to its execution rests with the President." 188 Butler pointed out that Congress had ratified President Lincoln's suspension of habeas corpus and establishment of martial law, thus ending any debate over who had the power to initiate such acts. ${ }^{189}$

Arguments concluded on March 13, 1866. On April 3, the Court issued an order directing the writ of habeas corpus be issued because the Military Commission had had no jurisdiction to try and sentence the defendants. The opinion of the Court, however, was not read until the beginning of the next term in December 1866. Judge David Davis returned to Bloomington, Illinois to write what would become his legal career's crowning achievement. Joining Davis's opinion for the majority were three of the four Democratic

\footnotetext{
${ }^{188}$ Benjamin F. Butler, "Reply of Benjamin F. Butler for the United States," quoted in Klaus, The Milligan Case, 220.

${ }^{189}$ Butler quoted in Klaus, 223.
} 
appointees from before the war, together with Stephen J. Field, a War Democrat appointed by Lincoln. Joining the concurring opinion of Chief Justice Chase were Lincoln appointees Swayne and Miller, as well as Justice Wayne, appointed by Jackson. Davis had actually lobbied Lincoln to elevate Swayne to Chief Justice in 1864. In a letter to the president, Davis pointed out that although Swayne had strong political opinions, he had never been an active partisan. "To place a mere partisan in such a position weakens an administration and lessens the respect that should attach to the decision of the Court." ${ }^{\prime 190}$ This letter illustrates, once again, Davis's anti-Partyism specifically when it came to the judiciary. Rising above the political fray became more than just lip-service for Davis, it became his career's endeavor. As we will see, his majority opinion in Milligan was reflective of his own political restraint on the bench and his unwavering concern over civil liberties.

Davis's majority opinion and Chase's concurring opinion were in agreement on the fundamental issue that the trial and sentencing of Milligan by the Military Commission was unconstitutional. Both opinions also rejected the Stanbery argument that a civilian's constitutional rights are suspended in times of war or rebellion, "inter arma, silent leges." However, on the point of congressional authority to establish military commissions, the two opinions differed sharply. This aspect of Milligan would be the hinge on which Radicals would view the opinion as a challenge to military

${ }^{190}$ David Davis to Abraham Lincoln, October 22, 1864, David \& Sarah Davis Family Correspondence, David Davis Mansion Historic Site, Bloomington, Illinois. 
commissions in the South. In order to fully understand Davis's reasoning in Milligan, a close reading and analysis of his majority opinion will be provided in the next chapter. 


\section{CHAPTER IV \\ “A LAW FOR RULERS AND PEOPLE" ${ }^{191}$ : \\ DAVID DAVIS'S MAJORITY \\ OPINION}

"Not a word is said in the opinion [Ex parte Milligan] about reconstruction, \& the power [to try by military commission] is conceded in the insurrectionary States." ${ }^{192}$ This letter by Davis to his brother in law Julius Rockwell is conclusive in making the case that Davis did not intend for Milligan to apply to the South. Yet, thorough historical analysis dictates that we must look for other pieces of evidence to make the strongest argument possible. So far, we have examined Davis's wartime record in which he only intervened in Northern military commissions while at the same time upholding Lincoln's war time actions in the Prize Cases. We must now look to the Milligan decision for further analysis. In its historical context, certain legal niceties and the political aspects of Davis's majority opinion shaped the Radical Republican view that the opinion applied to

\footnotetext{
${ }^{191}$ Ex parte Milligan, 71 U.S. 2 (Wall) 1866.

${ }^{192}$ David Davis to Julius Rockwell, February 24, 1867, David \& Sarah Davis Family Correspondence, David Davis Mansion Historic Site, Bloomington, Illinois.
} 
the South, striking down military commissions there and thus eliminating one of the few legal instruments to protect freedmen's rights. Davis, in reality, was tempering wartime excesses of nationalism and not leaving blacks to the mercy of Southerners. By examining the opinion, we can then begin to appreciate why Radicals, understandably, launched attacks on the Court in response to Milligan including reducing its members and limiting its appellate jurisdiction, all of which contributed to Reconstruction's alreadyexisting political instability and partisanship. We can also continue to trace Davis's evolution as a non-partisan civil libertarian, as he placed a heavy emphasis on the Bill of Rights over international law.

On December 17, 1866, the following term after oral argument, the Court delivered its opinion in what is now called the "Old Senate Chamber" at the Capitol building. The room teemed with attorneys and members of Congress. Journalists from the Associated Press and the Senate official reporter were ordered by the clerk of the court not to take any notes whatsoever because the Court did not want anyone misinterpreting or misstating the opinion. Not until January 1, 1867 was the opinion published in full. ${ }^{193}$

Writing for the majority, Davis held that military commissions and the laws and usages of war that establish them "can never be applied to citizens in states which have upheld the authority of the government, and where the courts are open and their process

${ }^{193}$ Klaus, The Milligan Case, 47. 
unobstructed." 194 Neither the President nor Congress had the authority to establish such military trials. After outlining the facts of the case, including the proceedings of the Military Commission, Davis provided an analysis of whether or not the Military Commission had jurisdiction to try and sentence Milligan. To this Davis concluded, "The importance of the main question presented by this record cannot be overstated; for it involves the very framework of the government and the fundamental principles of American liberty."195 With this sweeping statement, Davis began outlining a firm remonstration of the government's actions against Milligan and of others in the North who had faced trial by military commissions. It was for those same Northern Peace Democrats that he had intervened for throughout the Civil War.

He began by responding to Stanbery's argument that the Supreme Court did not have jurisdiction to hear Milligan's case due to its ex parte nature and that all cases before the Court had to have two opposing parties. Davis concluded that even though it was docketed as an ex parte case, notice was given at the Circuit Court level to Indiana's District Attorney, who did in fact appear and agree to have the habeas corpus petition certified by Davis and McDonald. When the two judges could not agree, it was submitted to the Supreme Court for consideration. ${ }^{196}$ While not abundantly clear nor even really vital to the heart of my principle contention, Davis concluded that he and his colleagues could hear Milligan's case as ex parte, due to the fact that the District Attorney appeared in Circuit Court on behalf of the government. In other words, in

\footnotetext{
${ }^{194}$ Milligan, 121.

195 Milligan, 110.

${ }^{196}$ Milligan, 115.
} 
Davis's mind because the two opposing sides were present in Circuit Court (Milligan and the District Attorney) it was not actually an ex parte case but rather a normal case consisting of two parties.

In response to Butler's argument that Lincoln's suspension of habeas corpus authorized the military arrest and trial of Milligan, Davis stated that, "The suspension of the writ does not authorize the arrest of any one, but simply denies to one arrested the privilege of this writ in order to obtain his liberty." ${ }^{197}$ In other words, habeas corpus has nothing to do with military trials, but rather the ability to challenge one's detention. Davis went on to acknowledge the circumstances under which the president had authority to suspend the writ. He stated that when the public safety demanded, the president could arrest a suspected person without giving a cause on return to a writ of habeas corpus. "But it was not contemplated that such person should be detained in custody beyond a certain fixed period, unless certain judicial proceedings, known to common law, were commenced against him." ${ }^{198}$ Taking line of argument from Black, Davis noted that Milligan had not been indicted by a Grand Jury and that according to the Habeas Corpus Act of 1863 , he was thus entitled to be released from military custody.

Davis finally concluded that the Court did have jurisdiction to hear Milligan's case by virtue of the fact that the Supreme Court had the authority to review habeas corpus petitions and in Milligan's petition he plead that he had been detained under order of the President, that he was a citizen of Indiana and had never been in the military, and

\footnotetext{
${ }^{197}$ Milligan, 116.

${ }^{198}$ Milligan, 116.
} 
that the Grand Jury in Indiana had adjourned without filing any indictment against him, all in violation of the Habeas Corpus Act of $1863 .{ }^{199}$

He then proceeded to address counsel's arguments in chief but not before stating the controlling question once more: Had the Military Commission jurisdiction to try and sentence Milligan? Driving home the importance of the case before the Court, Davis again pronounced, "No graver question was ever considered by this court, nor one which more nearly concerns the rights of the whole people; for it is the birthright of every American citizen when charged with crime, to be tried and punished according to the law."200 That law, as he would spell out in his majority opinion, was the United States Constitution, specifically the Bill of Rights. This would be in direct opposition to Lincoln's use of international law via the Commander-in-Chief clause.

When he took office, Lincoln's knowledge and experience with international law, specifically the laws of war, was negligible. Yet, over the course of the war he would learn to use the laws of war to the North's advantage and even go so far as to redefine them. Historically, the laws of war had humanitarian limits. One of these limits was the permanent confiscation of personal property. John Fabian Witt in Lincoln's Code points out, "Even if Lincoln had thought it prudent to emancipate slaves in Missouri (in reference to General John Frémont's emancipation declaration of 1861) he concluded that the customs and usages of warfare prevented him from doing so." ${ }^{201}$ But as the war wore on, Lincoln stepped closer to emancipation. In May 1862, Major General David Hunter

\footnotetext{
199 Milligan, 118.

${ }^{200}$ Milligan, 119.

${ }^{201}$ Witt, Lincoln's Code, 198.
} 
mirrored Frémont's emancipation order, this time in South Carolina. Again Lincoln revoked the order stating, "Whether at any time, in any case, it shall have become a necessity indispensable to the maintenance of the government, to exercise such supposed power, are questions which, under my responsibility, I reserve to myself."202 Here we see for the first time Lincoln envisioning the possibility of emancipation but only at the necessary time defined by himself and only through his authority as Commander-inChief. In July 1862, Lincoln officially declared that emancipation of the slaves was a necessary war measure warranted by military necessity. As Witt notes, "The military necessity test tethered the means allowed to the justice of the end in view. Justice-God's justice-was precisely what Lincoln had in mind." 203 Because Lincoln believed the North's cause was just and superior, he redefined the humanitarian limits of confiscation within the laws of war. It was the laws of war that also allowed for the criminal trial of individuals by military commissions and that upheld the authority of the executive branch in the role of Commander-in-Chief, as when Lincoln used emancipation as a military necessity. ${ }^{204}$

\section{William Blair in With Malice Toward Some: Treason and Loyalty in the Civil} War Era argues that while Lincoln did use international precedents in blockading the South, emancipating slaves, and curtailing civil liberties such as habeas corpus, it is doubtful that he consciously enlisted international law to defend his actions. When he defended the Emancipation Proclamation in a letter to James C. Conkling, he explained

\footnotetext{
202 Abraham Lincoln quoted in Ibid., 208.

${ }^{203}$ Witt, 218.

${ }^{204}$ Ibid., 368.
} 
how he used both domestic and international law. Lincoln insisted that the proclamation endowed the Commander-in-Chief "with the law of war, in time of war." He then asked, "Is there-has there ever been-any question that by the law of war, property, both of enemies and friends, may be taken when needed?"205 It was this wide interpretation of the Commander-in-Chief Clause that Lincoln wielded to not only emancipate the slaves and blockade Southern ports but more importantly authorizes the military trial of civilians in the North.

Davis, in his majority opinion, continued with an analysis of the $4^{\text {th }}$ Amendment, forbidding unreasonable searches and seizures; the $5^{\text {th }}$ Amendment, requiring indictment by a grand jury and the right not to be denied of life, liberty, or property except by due process; and the $6^{\text {th }}$ Amendment, providing the right to a jury trial in all criminal cases; all of which had, in his view, been violated by the Military Commission that convicted Milligan. Davis contended that the Military Commission did not possess authority because the $4^{\text {th }}, 5^{\text {th }}$, and $6^{\text {th }}$ Amendments were guaranteed to all United States citizens, in war and peace. "These securities for personal liberty thus embodied, were such as wisdom and experience and demonstrated to be necessary for the protection of those accused of crime."206 Therefore, according to Davis, the Constitution (Bill of Rights) superseded the laws of war (international law.)

Davis then continued with perhaps the most famous passage of the opinion:

\footnotetext{
${ }^{205}$ Abraham Lincoln to James C. Conkling quoted in William C. Blair, With Malice Toward Some: Treason and Loyalty in the Civil War Era (Chapel Hill: The University of North Carolina Press, 2014), 99. ${ }^{206}$ Milligan, 121.
} 
The Constitution of the United States is a law for rulers and people, equally in war and in peace, and covers with it the shield of protection of all classes of men, at all times, and under all circumstances. No doctrine... was ever invented by the wit of man than that any of its provisions can be suspended during any of the great exigencies of government. Such a doctrine leads directly to anarchism or despotism... 207

Here we see an apparent contradiction in terms. If the Constitution applies to all in both peace and war, how could Milligan have applied only to those military commissions in the North and not in the South? And would this not eliminate all protections for Black defendants facing all white juries in the South just as Davis's radical opponents contended?

According to her provocative dissertation, Karin Petlack, in this period Black freedom could come only at the expense of white civil liberties. For instance, in Cincinnati when the war started, whites voted in a Democratic mayor whose racism and corruption spread throughout the city. Frequent assaults on Blacks occurred. In 1863, a Republican mayor was elected. Immediately he replaced the corrupt police force and a new Union general was appointed to command the military district. This new general issued an order that all persons supporting the Confederacy through actions or speech would be arrested and subject to hanging. The restriction of white civil liberties allowed African Americans to establish their first newspaper, expand their churches and school board, and walk the streets of Cincinnati free from attacks by white citizens and the

${ }^{207}$ Milligan, 121. 
police. $^{208}$ If Petlack is correct, then only military law could protect Black freedom during the Civil War and Reconstruction. And it was precisely this military protection that Davis seemed to deny to African Americans in Ex parte Milligan.

One could argue that this passage is a reflection upon Davis's poor drafting abilities, which he acknowledged himself. He may have been caught up in the fervor of defending civil liberties that he was unaware of how contradictory his statement really was. One could also argue that in the back of his mind, this standard could only be applied to those who actually upheld and respected the laws of the federal government, thus eliminating the states in actual rebellion.

Davis went on to explain that the Military Commission that tried Milligan was not a legitimate court, established by Congress under Article III of the Constitution. Nor could it have convened on the mandate of the President because his powers were limited to executing the laws, not making them. Even Lincoln's use of international law and the Commander-in-Chief Clause did not authorize the use of military commissions, according to Davis. The laws and usages of war "can never be applied to citizens in states which have upheld the authority of the government, and where the courts are open and their process unobstructed.",209

This was a crucial formulation. It was the first passage in Davis's majority opinion signaling that he intended Milligan to apply only to the North. If, according to Davis, international law and thus military commissions could never be used in states

${ }^{208}$ Petlack, "A Dilemma of Civil Liberties," 7.

${ }^{209}$ Milligan, 122. 
where federal authority was upheld, then it follows that military commissions could be used in the South where federal authority obviously had not been upheld. Like Black, Davis also pointed out that the civilian courts were open and functioning in Indiana and therefore "no usage of war could sanction a military trial there for any offence whatever of a citizen in civil life, in no wise connected with the military service."210 For Davis then, international law (laws and usages of war) should not apply to non-combatant citizens in areas where civilian courts were open and functioning.

In an obiter dicta regarding Congressional authorization of military commissions, (a remark made, or opinion expressed, by a judge, in his decision upon a cause... and not necessarily involved in the determination of the cause, $)^{211}$ Davis stated, "Congress could grant no such power [to establish military commissions]; and to the honor of our national legislature be it said, it has never been provoked by the state of the country even to attempt its exercise." 212 The question of Congressional authority to convene military commissions was not one of the issues raised before the Supreme Court in this case. Davis acknowledged at the beginning of his majority opinion that the controlling question in the case was whether the military commission had jurisdiction to try and sentence Milligan. Yet, in his opinion, Davis went out of his way to declare that Congress could not constitutionally authorize the use of these tribunals even if it chose to do so.

The Supreme Court's role in deciding whether a Congressional law was unconstitutional was first established by Chief Justice John Marshall in Fletcher v. Peck.

\footnotetext{
${ }^{210}$ Milligan, 123.

211 Black's Law Dictionary, $5^{\text {th }}$ ed., s.v. "obiter dicta."

${ }^{212}$ Milligan, 124.
} 
In this 1810 case, Justice Marshall cautioned that the act of declaring a Congressional law unconstitutional was "a question of much delicacy, which ought seldom, if ever, to be decided in the affirmative, in a doubtful case." ${ }^{213}$ The Supreme Court, therefore, could declare an act of Congress unconstitutional only if there were no other grounds for ruling on the case in question. Despite the fact that Justice Fields went to great lengths in pointing out that no question of Congressional authority was before the Court, the majority opinion nonetheless maintained that Congress could not constitutionally establish military commissions even if it had wanted to do so.

This obiter dicta statement was the spark that lit the fire of Radical Republican opprobrium for Davis's majority opinion. A more detailed analysis will be given in the next chapter regarding Congressional Reconstruction, but at this point it is only necessary to point out that Radicals would rely on military commissions in the South to protect freedmen from all-white juries and judges who obviously were not concerned about their civil and legal rights. Upon reading that Davis had apparently struck down their ability to use military commissions in the South, they understandably felt attacked by the Court.

But if Davis intended for Milligan to only apply in the North, and allow military commissions to remain in the South, why did he declare Congress unable to establish them? A close reading of the opinion reveals that this obiter dicta statement was made in the context of the laws and usages of war being unconstitutional in those states that upheld the authority of the federal government and whose civilian courts were open and

${ }^{213}$ Fletcher v. Peck, 10 U.S. 87 (1810). 
functioning. Executive use of military law where the authority of the federal government was unquestioned and where the courts were open and functioning WAS constitutional. I contend, therefore, that while not stated as clearly as it could have been, Davis was trying to say that while neither Congress nor the Executive had the authority to establish military commissions in the North, he was leaving open the ability of Congress and not the Executive to establish military commissions in the South.

A letter written by Davis to his brother-in-law, Julius Rockwell, in 1867 may shed some light on Davis's obiter dicta statement. On February 24, Davis wrote:

The right to try by a military tribunal was claimed as an executive power. We held that the provisions of the constitution were irrepealably (sic) and could not be suspended. Did it not logically follow that Congress could not repeal? Believing as we did that the whole thing was fundamental, would it not at once have been unmanly and unworthy a court to have confirmed the denial to the executive and would it not at once have been claimed that we admitted Congress could do it? How can a provision be irrepealable and yet Congress repeal it, disregard it, or suspend it? The whole argument, such as it is, is to show the irrepealable character of the amendments; nothing else. $^{214}$

Whether this was Davis's actual logic at the time he drafted Milligan is uncertain. Yet, if we take him at face value, Davis was simply stating that due to the Constitution's inviolable nature, since the President could not authorize military commissions in the North, Congress could not either. Thus the Constitution is a law for all rulers and people.

${ }^{214}$ David Davis to Julius Rockwell, February 24, 1867, David \& Sarah Davis Family Correspondence, David Davis Mansion Historic Site, Bloomington, Illinois. 
But while it is misleading, even here Davis was NOT saying that Congress could note establish military commissions in the South. In his letter to Rockwell, Davis continued, "I used the words 'Congress could grant no such power' in the wrong place, but in the subsequent part of the opinion I think I proved it." 215 While Davis was not specific as to what he meant here, nor did he explain where he should have placed it, a continued analysis of his majority opinion will show that he intended for Milligan to apply only to military commissions in the North.

In rejecting Stanbery and Butler's argument that martial law authorized the use of military commissions, Davis agreed with Garfield and Field's arguments that no such proposition can stand under a republican government since martial law renders the military independent and superior to civil authority. Yet, he acknowledged that the nation should not always expect to have "wise and humane" rulers. "Wicked men, ambitious of power, with hatred of liberty and contempt of law, may fill the place once occupied by Washington and Lincoln."216 Davis argued that the Founders knew there would be times of war and that abuses of power were more likely to occur during these periods of calamities. Therefore, they included certain safeguards that could not be disturbed, except for habeas corpus. Davis recognized that during the Civil War there was an emergency that demanded the government should not be required to have produced the persons arrested in answer to a writ of habeas corpus. "The Constitution goes no further. It does not say after a writ of habeas corpus is denied a citizen, that he

$$
\begin{aligned}
& { }^{215} \text { Ibid. } \\
& { }^{216} \text { Milligan, } 126 .
\end{aligned}
$$


shall be tried otherwise than by the course of the common law."217 As he had stated earlier in rejection of Butler's argument that Lincoln's suspension of the writ justified the use of military commissions, Davis again emphatically stated that habeas corpus has nothing to do with the trial process. It is simply an instrument to be used to determine the legality of one's detention. No mention is made of their trial outside of the normal civil judicial process when those civil courts are open.

In adopting Garfield's assertion that no military necessity was present in Milligan's situation that justified martial law, Davis stated that martial law "cannot arise from a threatened invasion. The necessity must be actual and present; the invasion real, such as effectually closes the courts and deposes the civil administration." ${ }^{218}$ Davis went on to state that there are instances in which martial law may be established, specifically in foreign invasion or civil war, when the courts are actually closed, and where the theatre of active military operations exist. "It is also confined to the locality of actual war. Because, during the late Rebellion it could have been enforced in Virginia, where the national authority was overturned and the courts driven out, it does not follow that it should obtain in Indiana." ${ }^{219}$ Here, Davis clearly established his belief that martial law, the replacement of civilian law by military law, could be used in the South but not in the North.

In closing, Davis admitted that if Milligan had been found guilty of the crimes imputed to him by a civilian court, he should have faced severe punishment. For Davis

\footnotetext{
${ }^{217}$ Milligan, 127.

${ }^{218}$ Milligan, 128.

${ }^{219}$ Milligan, 128.
} 
though, it was not easy for him to see how Milligan could have been treated as a prisoner of war, liable under the laws of war, "when he lived in Indiana for...twenty years, was arrested there, and had not been, during the late troubles, a resident of any of the states in rebellion." 220 The fact that he was accused of being involved in a plot, however improbable, to overthrow the government and establish an independent Northwestern Confederation, a plot that involved freeing Confederate soldiers and stealing weapons, did not make it a military manner. In Davis's mind, Milligan could not have pled the rights of war, for he was not engaged in acts of hostility against the federal government.

A close reading of the majority opinion in Milligan thus sheds some light on where and for whom Davis intended it to apply. His repeated emphasis that Milligan was not a "resident" of any "of the rebellious states" hints at the rule that residents of the South were enemies with no constitutional rights to protect them against military commissions. This would fall in line with the Prize Cases decision, in which he was a member of the majority. There, the Court held that all who lived in enemy territory, were no longer under the protection of the common law, but rather subject to the laws and usages of war (international law). Additionally, Davis's analysis of the locality of war seems to have made clear that military commission were permissible only in the South.

Salmon P. Chase stated in his concurring opinion, that the Habeas Corpus Act of 1863 proved Congress meant for civilians to be tried in civilian courts, not military courts, and therefore Milligan should have been released. As stated previously, this act

${ }^{220}$ Milligan, 132. 
allowed the detention of individuals only until a Grand Jury had met in the district where they were held and if they were not indicted by the Grand Jury, the act required their discharge. ${ }^{221}$ Chase also agreed with Davis that, "The holding of the Circuit and District Courts of the United States in Indiana had been uninterrupted. The administration of the laws in the Federal courts had remained unimpaired."222 However, he disagreed with Davis's obiter dicta statement. Chase declared that Congress did in fact have the authority to convene such military trials of civilians, even though it had not tried to do so during the war. In opposition to Davis, Chase's opinion stated:

In Indiana...the state was a military district, was the theater of military operations, had been actually invaded, and was constantly threatened with invasion. We cannot doubt that, in such a time of public danger, Congress had power, under the Constitution, to provide for the organization of a military commission, and for trial by that commission of persons engaged in this conspiracy. The fact that the Federal courts were open was regarded by Congress as a sufficient reason for not exercising the power; but that fact could not deprive Congress of the right to exercise it. ${ }^{223}$

As a Radical Republican himself, Chase disagreed with Davis' contention that Congress did not possess the authority to establish military commissions. Alongside other Radicals, he believed this stripping of Congressional power would be detrimental to Reconstruction. At the end of his opinion, Chase remarked, "And we are unwilling to

\footnotetext{
${ }^{221}$ An Act relating to Habeas Corpus, and regulating Judicial Proceedings in Certain Cases, U.S. Statutues at Large 755 (1863).

${ }^{222}$ Milligan, 134.

${ }^{223}$ Milligan, 141.
} 
give our assent by silence to expressions of opinion which seem to us calculated...to cripple the constitutional powers of the government, and to augment the public danger in times of invasion and rebellion."224 Chase seems to have been extremely suspicious of Davis's motivations when he used the word "calculated." This may have inadvertently planted the seed for Radicals to view the majority opinion as a partisan attack on Reconstruction. As we have seen through a close reading of the majority opinion, Davis did not intend for Milligan to remove the authority of military commissions in the South. On the surface, however, it is entirely understandable why Radicals interpreted his opinion negatively, in light of Davis's swipe at congressional authority.

Apart from the opinion itself, there is very little documentary evidence as to Judge Davis' thoughts in regards to Milligan. The David Davis papers are incomplete, especially for 1866, the year Milligan was decided. In fact, there are only a few known family letters that even mention the Supreme Court case. On October 5, 1866, Sarah Davis wrote a letter to her son, George Perrin Davis, and mentioned that his father "was quite absorbed in his opinion... O, how I hope it may be finished tomorrow-for you dear Father is quite worn-and dreams of it at night."225 His wife even saw how important the case was for him. On January 14, 1867, Mrs. Davis wrote her husband, informing him of how "[T]he Pantagraph talks so harshly of the "Milligan case" and the decision of the

${ }^{224}$ Milligan, 142.

${ }^{225}$ Sarah Davis to George Perrin Davis, October 5, 1866, David \& Sarah Davis Family Correspondence, David Davis Mansion Historic Site, Bloomington, Illinois. 
five Judges that I will not send it." ${ }^{" 26}$ The Republican-leaning Pantagraph had taken exception to Milligan:

We do not complain of the court for having decided to discharge Milligan; for after having determined that military law did not prevail in Indiana at the time of his arrest, and that he was therefore entitled to the benefit of the statute, they could do no less. But with Chief Justice Chase, we think the court should have stopped there, and not volunteered opinions which give alarm to all but rebels and their sympathizers. ${ }^{227}$

It seems as if the writer of this article was confused as to who made the obiter dita statement. As we will see in a moment, according to Republicans it was Davis who "volunteered opinions" that comforted "rebels and their sympathizers." But in addition to this, we will also see that public opinion in regards to Milligan varied along the political spectrum.

On January 30, 1867, Judge Davis wrote his wife, alluding to the public reaction to the published opinion. "Having been attacked so much in the papers, I thought that Judge Rockwell would have written me. The opinion is not much talked of now...its fate must depend on the judicial mind of the country." 228 Yet, as we have seen, we do know that throughout the Civil War, Judge Davis was adamantly against the use of military commissions in the North. In an 1866 letter to Williams Herndon, Davis remarked, "Mr. Lincoln was advised and I so advised him, that the various military trials in the Northern

${ }^{226}$ Sarah Davis to David Davis, January 14, 1867, David \& Sarah Davis Family Correspondence, David Davis Mansion Historic Site, Bloomington, Illinois.

${ }^{227}$ Pantagraph, January 8, 1867, quoted in Fairman, History of the Supreme Court, 218-219.

${ }^{228}$ David Davis to Sarah Davis, January 30, 1867, David \& Sarah Davis Family Correspondence, David Davis Mansion Historic Site, Bloomington, Illinois. 
and Border States, where the Courts were free and untrammeled, were unconstitutional and wrong." 229

One can view Davis's majority opinion in more than one light. On one hand, Davis took an extreme Copperhead position when he struck down military commissions in the North and upheld the Bill of Rights over the laws and usages of war. It is also important to remember that throughout the war, Davis intervened on behalf of several Copperheads. On the other hand, Davis held to his Whig roots and upheld the rule of law in his majority opinion. As stated before, Lincoln believed that the exigencies of the rebellion clothed him in enormous war powers in order to preserve the Union. Davis, however, while upholding the majority of Lincoln's war-time actions, believed that the Constitution and the laws of the nation should have been upheld at all costs, thus his opposition to military commissions in the North. Milligan can also be seen as a reflection upon Davis's anti-Partyism and his growing dislike of politics in general. As we have seen, despite his opposition to Peace Democrats, he consistently intervened on their behalf.

Davis's mindset at this time is important to note, in order to frame his continued judicial impartiality while on the bench. Before oral argument in Milligan, he wrote a letter to his son stating, "I devote myself wholly to the duties of the bench and don't mingle with politicians at all." ${ }^{230}$ A few months after oral argument, Davis wrote to Julius Rockwell saying, “American politics don’t interest me much nowadays \& I hardly

\footnotetext{
${ }^{229}$ David Davis to William Herndon, September 1866, quoted in Klaus, The Milligan Case, 51.

${ }^{230}$ Davis to George Perrin Davis, February 18, 1866, David \& Sarah Davis Family Correspondence, David Davis Mansion Historic Site, Bloomington, Illinois.
} 
read the newspapers enough to keep up with the current news of the day."231 These two letters illustrate Davis's frame of mind before hearing Milligan and shortly before drafting his majority opinion. It is my contention, therefore, that Davis remained politically restrained during the course of Lambdin P. Milligan's case.

As discussed in chapter 1, Davis was a Whig for most of his life. Whigs were known for holding the opinion that the Constitution provided broad powers to the federal government, including the creation of a national bank and funding the construction of canals, roads, and railroads. ${ }^{232}$ Why then, did he in Milligan not only take a swipe at executive wartime power but congressional power as well? After all, President Lincoln, who also spent most of his life as a Whig, took no issue with the broad powers he exercised during the war. The lack of documentary evidence in regard to Davis and Milligan do nothing to help answer this question. Therefore, I offer the following conjecture. As prairie lawyers, both Lincoln and Davis rarely encountered cases that dealt with the United States Constitution. The majority of their practice encompassed the common law and for Davis consisted largely of collection cases. Davis had not even argued one single appellate case as opposed to Lincoln's countless appellate cases. ${ }^{233}$ As Mark Neely points out, even as president, Lincoln "rarely thought abstractly about the Constitution and the laws... and did not characteristically reach first for a copy of the U.S. Constitution when confronted with a political or social problem... because thinking in

${ }^{231}$ Davis to Julius Rockwell, August 9, 1866, David \& Sarah Davis Family Correspondence, David Davis Mansion Historic Site, Bloomington, Illinois.

${ }^{232}$ Holt, The Rise and Fall of the American Whig Party, 24-30.

${ }^{233}$ McGinty, Lincoln \& The Court, 113. 
constitutional ways did not come naturally to him."234 Davis, on the other hand, was forced to become better acquainted with constitutional ways when he ascended to the Supreme Court. His increasing breadth of constitutional history and principles, while a justice, may have affected the Milligan decision's legally liberal nature.

Other jurists saw Davis' opinion as detrimental to post-war policy. Attorney John Jay, grandson of Chief Justice John Jay, wrote to Chase stating, "If, as the public begin to fear, [the Court's] denial of the powers of Congress is any index to the view they are prepared to take of the great questions that will come before them in reference to Reconstruction, our situation is certainly a grave one."235 Jay not only feared the short term consequences of Milligan, but the long term decision-making by the Court in regards to Reconstruction as well. If military commissions in the South were being struck down, in his view, would the Court likewise strike down other Reconstruction provisions? Again, we will see in the next chapter, that Davis actually upheld Reconstruction measures in the South.

Democrats and Democratic newspapers, of course, immediately praised Davis's opinion. The New York World exclaimed, "The fact that the Supreme Court has escaped the servile contamination of the times, and pronounces an independent opinion which vindicates a party so traduced and maligned as the Democracy, is full of encouragement."236 The Enquirer wrote, "It has been decided by the Court that Congress

${ }^{234}$ Neely, The Fate of Liberty, 215.

${ }^{235}$ John Jay to Salmon P. Chase, January 5, 1867, quoted in Warren, The Supreme Court in United States History, 428.

${ }^{236}$ New York World, January 12, 1867, quoted in Ibid., 438. 
has no power to authorize military commissions. The upright action of the Supreme Court has inspired the country with new hope of a speedy tranquilization."237 The Little Rock Arkansas Gazette said that Milligan "encourages the belief that the Supreme Court would become a barrier to the sweeping progress of a ruthless fanaticism."238 Even some Republican newspapers praised the opinion. The Louisville Democrat exclaimed, "that in the worst days of party insanity and misrule, there is one conservative department of the Government unawed and uninfluenced by the arbitrary power of Jacobinism. It is said the Radicals, of the legal persuasion, grow sick at heart when they contemplate the decision."239 The New Orleans Picayune hailed the decision in almost Biblical proportions. "This emerging of the Supreme Court above the atmosphere of partisan strifes and tumultuous popular passions into the region of calm and unclouded justice is the rising above the waters of the Ararat, on which the ark of the constitution may repose in security."240 The Springfield (Massachusetts) Republican saw Milligan as nothing more than "a reaffirmation of the sacred right of trial by jury," and it condemned "popular alarm or partisan animosity."241 The Democratic papers read Milligan as far more sweeping as it actually was. For them, Democrats thought that no military commissions would be allowed. Republicans also misread Davis's opinion but in a negative rather than a positive light. In their minds, there would be no military commissions in the South to protect freedmen's rights.

${ }^{237}$ The Enquirer, December 19, 1866, quoted in Fairman, History of the Supreme Court, 215.

${ }^{238}$ Arkansas Gazette, December 19, 1866, quoted in Ibid., 215.

${ }^{239}$ Louisville Democrat, January 5, 1867, quoted in Ibid., 220.

${ }^{240}$ Picayune, January 8, 1867, quoted in Ibid., 221.

${ }^{241}$ Springfield Republican, January 2, 1867, quoted in Fairman, 219. 
No other historian has more accurately captured the contrasting responses to Milligan between modern day legal scholars and Radical Republicans after it was published than Charles Warren. In his 1935 book The Supreme Court in United States History, Warren observed:

This famous decision has been long recognized as one of the bulwarks of American liberty, that it is difficult to realize now the storm of invective and opprobrium which burst upon the Court at the time when it was first made public. By the Reconstructionists the decision was regarded as a reversion to the theory of constitutional law... and they asserted that the Court had now joined hands with President Johnson in an effort to destroy the Congressional plans for Reconstruction. ${ }^{242}$

The Congressional plans for Reconstruction, of course, were to establish and protect civil and political rights for freedmen throughout the South. Ironically misreading the decision, Radical newspapers and politicians alike reviled Davis's apparent attack on their vision for a post-war South.

Much like John Jay, The Nation, a New York, Republican-leaning weekly magazine, saw Milligan as an attack on Reconstruction and what he saw as legal consequences for freedmen in the South. "Courts such as now exist in the South are no more protection to the freedmen than if they did not exist." ${ }^{243}$ Jay and The Nation obviously understood that all-white, local Southern courts were not to be relied upon to

${ }^{242}$ Warren, 427.

${ }^{243}$ The Nation, 3:510 (December 27, 1866), quoted in Fairman, 215. 
uphold civil and legal rights for freedmen. The American Law Review opined on Davis's

obiter dicta statement:

Had [the Court] in truth simply adhered to their plain duty as Judges, they could have united in one opinion on this most important case. Instead of approaching the subject of the powers of the coordinate branches of the government as one of great delicacy...they seemed eager to go beyond the record...the more a case before the Supreme Court assumes a political aspect, the more cautious should the Judges be to confine themselves within their proper limits... ${ }^{244}$

The American Law Review clearly saw Davis's opinion as a political attack on Congressional Reconstruction.

The Republican New York Times stated:

The Supreme Court, we regret to find, throws the great weight of its influence into the scale of those who assailed the Union and step and step impugned the constitutionality of nearly everything that was done to uphold it. The whole Copperhead press exults over the decision. ${ }^{245}$

It is not clear whether the Times thought that Davis was taking the side of the South or Peace Democrats. Either way, they accurately depicted the Peace Democrat rapture over the decision.

Harper's Weekly, which supported the Lincoln administration during the war, wrote, "Like the Dred Scott decision, it is not a judicial opinion-it is a political act. The

${ }^{244}$ The American Law Review (April 1867, I, 572), quoted in Warren, 441-442.

${ }^{245}$ New York Times, January 3, 1867, quoted in Ibid., 429. 
Indiana decision operates to deprive the freedmen in the late rebel States, whose laws grievously outrage them, of the protection of the freedmen's courts." ${ }^{246}$ This Republican newspaper probably comes the closest to representing how Radicals viewed Davis's majority opinion. Without military commissions (freedmen's courts) in the South, their newly acquired rights would be severely jeopardized.

In respects to Davis's obiter dicta statement about congressional authority, the Republican mouthpiece, Chicago Tribune stated, "Such a stepping aside from the case in hand was, we think, unnecessary, uncalled for and unwise, and will do much to revive the unfavorable impression of the tribunal."247

Radical public opinion perceived Davis' majority opinion in Ex parte Milligan as a direct attack on Radical Republicans and their plans for Reconstruction in the South. Southern public opinion perceived the opinion as a blanket of protection from post-war military rule. Northern Democrat public opinion said it was a vindication of military commissions such as in Milligan and Vallandigham's cases. All three ends of the political spectrum were wrong. I contend it was simply not the case that Davis intended to limit Reconstruction in this way. In a letter to his brother-in-law, Julius Rockwell, Davis explained, "not a word is said in the opinion about reconstruction, \& the power [to try by military commission] is conceded in the insurrectionary States."248 It was not the use of military commissions in the South that Davis opposed, it was their use in the

246 “The New Dred Scott," Harper's Weekly, January 19, 1867, quoted in Robert Fridlington, The Reconstruction Court (New York: Associated Faculty Press, 1987), 80.

247 Chicago Tribune, January 4, 1867, quoted in Fairman, 218.

248 David Davis to Julius Rockwell, February 24, 1867, David \& Sarah Davis Family Correspondence, David Davis Mansion Historic Site, Bloomington, Illinois. 
North. Unfortunately, the Radicals in Congress did not have the opportunity to read this letter and would, understandably, see Milligan as an attack on their plans for Reconstruction. One could even make the argument that Davis was not accurately characterizing his own opinion. However, as we will see in the next chapter, despite the Radical Republicans view and reaction to Milligan as an attack on Congressional Reconstruction, Davis's voting record in subsequent Supreme Court cases allowed military commissions to remain intact in the Reconstruction South. 


\section{CHAPTER V}

"THE CONSTITUTIONAL TWADDLE OF MR. JUSTICE DAVIS"249: EX PARTE MILLIGAN AND RECONSTRUCTION

Post-war reconciliation is invariably challenging, whatever the nature of the conflict. But it is exceptionally difficult in the aftermath of civil wars. Conflict over shared territory, a shared political system, or competing ideologies produces formidable ongoing problems regardless of whether civil war results in separation or reunion. For the American Civil War, one of the post-war conflicts would be over David Davis's majority opinion in Ex parte Milligan and its interpretation by Radical Republicans. ${ }^{250}$ In

\footnotetext{
${ }^{249}$ The New York Herald, January 2, 1867, quoted in Warren, The Supreme Court in United States History, 432.

${ }^{250}$ As outlined in chapter 1 , this thesis attempts to contribute not only to the historiography of David Davis and the legal history of the Civil War but also to the historiography of the judicial politics of Reconstruction. Legal historians such as Harold Hyman and William M. Wiecek initially led the charge in this field. Harold Hyman's 1973 book A More Perfect Union: The Impact of the Civil War and Reconstruction on the Constitution argued that Reconstruction really began immediately after the firing on Fort Sumter when Union armies began to occupy seceded territories. This experience led to early phases of state restoration. Hyman stated that Republicans wanted to return the nation and states to pre-war arrangements and that therefore no major centralization of federal power, particularly the Supreme Court, occurred after the war even though there was a decrease in state autonomy. Harold Hyman, A More Perfect Union: The Impact of the Civil War and Reconstruction on the Constitution (New York: Alfred A. Knopf, 1973). In 1982, Harold Hyman and William Wiecek co-authored Equal Justice Under the Law: Constitutional Development, 1835-1875. Hyman and Wiecek argued that the Thirteenth Amendment required the federal government to protect freedmen from discriminatory action by states or private individuals. Even though the amendment did not define these rights and liberties, Hyman and Wiecek state that the founders understood that they were rights to be expanded upon in the future of which the courts were to enforce. Harold Hyman and William Wiecek, Equal Justice Under the Law: Constitutional Development: 1835-1875 (New York: Harper and Row, 1982). Michael Les Benedict, one of our most imminent legal scholars, recently published a law review article, "Constitutional Politics, Constitutional
} 
order to understand the Radical reaction to Milligan it is necessary first to understand exactly what the role of military commissions were during Reconstruction. This will allow a clearer understanding of why Radicals were so concerned over Davis's reprimand of military commissions and why they understandably took action against the Supreme Court, leading to a more partisan and politically unstable environment during Reconstruction.

Milligan was handed down in the aftermath of Lincoln's assassination and in the early phases of Presidential Reconstruction. As a driving issue, race eventually became a constitutional issue of Reconstruction. ${ }^{251}$ Radical Republicans, such as Thaddeus Stephens, argued that the Confederacy was an "enemy nation" and thus the laws of war dictated military occupation by Union troops. Though they agreed with Stevens that the laws of war held between the armed forces of the Union so-called and those of the socalled Confederacy. Moderate Republicans, like President Lincoln, maintained that nevertheless, the Southern states had never left the Union thus entitling them to a full restoration of their political and legal rights, with the proviso of abolishing slavery, a

Law, and the Thirteenth Amendment," in which he argued that during the Nineteenth Century, the Supreme Court was not seen as the primary source for constitutional interpretation nor were its decisions seen as binding. Instead, constitutional issues were decided by the American people. Therefore, when Congress passed the Thirteenth Amendment, it did not expect the Supreme Court to be the primary body to enforce it. They expected it to be enforced through the political system. This may explain, in part, why Radical Republicans did not adhere to Davis's majority opinion in Milligan. Michael Les Benedict, "Constitutional Politics, Constitutional Law, and the Thirteenth Amendment," Maryland Law Review 71 no. 1 (2011). Most recently, in 2011, Pamela Brandwein in Rethinking the Judicial Settlement of Reconstruction argues that the Supreme Court did not intend to leave African Americans in the hands of southern white supremacy. Instead, the Court maintained that the federal government could intervene locally if states purposefully failed to protect African Americans' due process or property rights. Pamela Brandwin, Rethinking the Judicial Settlement of Reconstruction (New York: Cambridge University Press, 2011). This thesis most aptly joins with Brandwein in arguing that the blame for the failure of Reconstruction should not be laid on the Supreme Court the way it has been.

${ }^{251}$ Foner, Reconstruction, 273, xxiv. 
certain percentage taking a test oath, and several other conditions. ${ }^{252}$ Lincoln had consistently maintained that secession was illegal, and he could not very well hold it was legal now that the war was coming to an end.

Initially, President Johnson favored leniency when it came to readmitting the Southern states. Not only did he offer amnesty to southerners who took a loyalty oath, but he also allowed many former Confederates back into political office. He did require the Southern states to ratify the $13^{\text {th }}$ Amendment though. This meant that the political rights of the freedmen would be left to Southern state governments. "Black Codes" were quickly passed by Southern state legislatures which effectively restricted their political and economic rights by establishing a system of sharecropping and racial segregation. ${ }^{253}$ As W.E.B. Dubois best described it, "The slave went free; stood a brief moment in the sun; then moved back again toward slavery."254

Radical and some moderate Republicans in Congress had alternative plans for Reconstruction. Along with refusing to seat Southerners in their respective state governments, on April 9, 1866, three days after the Supreme Court decided Milligan, Congress passed the Civil Rights bill and on July 16, the Freedmen's Bureau bill, both over Johnson's veto. ${ }^{255}$ The Radicals also believed that military occupation and military law were the only mechanisms that could protect the freedmen's newly acquired political rights. In fact, a provision of the Freedman's Bureau Act provided for military

${ }^{252}$ Ibid., 273, 61-62.

${ }^{253}$ William Gillette, Retreat From Reconstruction: 1869-1879 (Baton Rouge: Louisiana State University, 1979), 4.

${ }^{254}$ W.E.B. Du Bois, Black Reconstruction in America (New York: Russell \& Russell, 1962), 30.

${ }^{255}$ Radicals alone did not have enough votes to override a veto, so moderate Conservative Republicans were a part of defeating Johnson on this bills. 
commissions to protect the rights of Black in the South. ${ }^{256}$ In his famous "Swing 'Round the Circle," Johnson campaigned in support of his Reconstruction plan and lambasted Congress for attempting to destroy it. Johnson's actions made it seem to a majority of Northerners that winning the war was being given away. As a result, the 1866 congressional elections led to a landslide victory for Radicals, thus ending Presidential Reconstruction and ushering in Congressional Reconstruction. ${ }^{257}$

A part of this military occupation was the use of military commissions to try Southern civilians. Despite Milligan's assertion that military commissions were unconstitutional when the civilian courts were open and functioning, military trials of civilians continued in the Reconstruction South. Mark Neely provides the following number of trials per year after the Milligan decision: 229 in 1866, 181 in 1867, and 104 in $1868 .^{258}$ What happened here? It was by no means the first time that another branch of government ignored a Supreme Court decision. Lincoln blatantly ignored the Taney Court on civil liberty issues in Ex parte Merryman. ${ }^{259}$

Less well known are the justifications given by Congressional Radicals for ignoring Milligan after the war. Understanding the partisanship in a post-Civil War America is vital to this story. Michael W. Fitzgerald's "Reconstruction Politics and the Politics of Reconstruction" explores how corruption and partisanship undermined the

${ }^{256}$ An Act to amend an act entitled "An act to establish a Bureau for the relief of Freedmen and Refugees," and for other purposes, U.S. Statues at Large 173 (1866).

${ }^{257}$ Michael Les Benedict, A Compromise of Principle: Congressional Republicans and Reconstruction, 1863-1869 (New York: Norton \& Company, 1974), 208, 202-203, 239-243, $294-314$.

${ }^{258}$ Neely, Jr., The Fate of Liberty, 176.

${ }^{259}$ Neely, Jr., Lincoln and the Triumph of the Nation, 64-65. 
effectiveness of the Reconstruction governments. ${ }^{260}$ The partisanship that Fitzgerald uncovers led Radicals to see Davis's majority opinion as an attack on their plans for Reconstruction. In doing so, Congress took several steps to reduce the power of the Supreme Court which only contributed to the political instability of Reconstruction.

Justice Chase and his Radical Republican colleagues had strongly opposed President Lincoln's Reconstruction policy of reuniting the United States. In opposition to Lincoln's 10\% plan back in 1864, the Radicals proposed the Ironclad Oath which prevented anyone who had supported the Confederacy from voting in Southern elections. Lincoln quickly pocket-vetoed the Wade-Davis bill, which made southern state readmittance to the Union contingent on taking the Ironclad Oath itself. ${ }^{261}$ The Radicals continued to lobby for a more aggressive war effort, the end of slavery, and the total destruction of the Confederacy. After the 1866 elections and after expelling the former Confederate Southern Congressmen in the $39^{\text {th }}$ Congress they had a majority of nearly 3 to 1 in the House, nearly 4 to 1 in the Senate, and took control of the Joint Committee on Reconstruction. Johnson ignored this Radical sweep and continued to insist on Southern state re-admittance. He called for a "return to the ancient landmarks" in order to assure "the perpetuity of our free institutions," and a restoration of "fraternal feeling." ${ }^{262}$ The only problem with this "perpetuity of our free institutions" was an underlying condition that freedmen be left to the mercy of local southern law. Thus, there was a need (from

${ }^{260}$ Michael W. Fitzgerald, "Reconstruction Politics and the Politics of Reconstruction," in Thomas J. Brown ed., Reconstructions: New Perspectives on the Postbellum United States (New York: Oxford University Press, 2006), 91-166.

${ }^{261}$ Foner, Reconstruction, 61-62.

${ }^{262}$ Fairman, History of the Supreme Court of the United States, 182. 
the Radical perspective) for judicial supervision in the South through the continued use of military commissions.

The United States Army played a vital role during Reconstruction. Their main purpose was to maintain law and order, as well as to protect freedmen and white Republicans from resentful, violent Southerners. The horrendous acts of the Klu Klux Klan nearly turned the South into a terrorist state in which lynching and voter intimidation were prevalent. ${ }^{263}$ The task of putting the lid on this violence fell on the shoulders of the U.S. Army, with the assistance of the Freedmen's Bureau. Soldiers were inadequate to handle the work load however. Two hundred-thousand troops were stationed in the South in 1865. By April 1866, there were less than forty-thousand troops and in October 1866 only twenty-thousand. ${ }^{264}$ Maintaining the law proved just as challenging as maintaining order. Thus military commissions were put into place so that law and order could be maintained. From the end of the war until January 1, 1869, there were 1,435 military trials of civilians in the South. ${ }^{265}$ Northern Republicans such as Thaddeus Stevens saw these tribunals as the only option to maintain a fair justice system for blacks in the face of local Southern judges and juries, while Southerners viewed them as a continuation of Republican tyranny. ${ }^{266}$

We will see what would become an emerging constitutional conflict not only between the Radical Republicans and President Johnson but also between the Radical

${ }^{263}$ Detlev F. Vagts, "Military Commissions: The Forgotten Reconstruction Chapter," American University International Law Review 23, no. 2 (2007): 234.

264 Vagts, "Military Commissions," 236-237.

265 Neely, The Fate of Liberty, 176.

266 Vagts, "Military Commissions," 244-245. 
Republicans and the Supreme Court, especially in response to David Davis's majority opinion in Ex parte Milligan. To be sure, based on his own racist tendencies Davis opposed such Radical Reconstruction ideas of black suffrage and equality. Even though he labeled himself a Republican, he leaned conservative Republican at best. Much later, in an 1868 letter to Massachusetts Republican Congressman Julius Rockwell, Judge Davis wrote, "The election last week passed off quietly but when I saw the degraded ignorance of the poor creatures, who were voting...I felt sad...Negro suffrage...may prove a measure of wisdom and good statesmanship, but I don't believe it."267 This tracks with what we have already seen with Davis's racial prejudices.

Just weeks before Davis issued his opinion in Ex parte Milligan, the election of 1866 resulted in a landslide victory for Radical Republicans. Consequently, Milligan was just as important for freedmen as it was for white civil liberties. Confident of their new majorities, the newly elected Radicals in Congress passed several pieces of legislation stripping the Supreme Court of its jurisdictional and appellate powers, in order to preserve their Reconstruction plans and to keep the Court at bay. These attacks on the Supreme Court by Radical Republicans came out of their understanding of Milligan's majority opinion which was that it struck down military commissions in Reconstruction South.

The actions that the Radicals took in response to Milligan included reducing its members and limiting its appellate jurisdiction over military commissions in the South.

${ }^{267}$ David Davis to Julius Rockwell, April 22, 1868, David \& Sarah Davis Family Correspondence, David Davis Mansion Historic Site, Bloomington, Illinois. 
These actions only made Reconstruction's politics more partisan. In an almost prophetic manner regarding Davis's obiter dicta statement about Congressional authority to establish military commissions, Radical Republican Congressman James F. Wilson of Iowa declared, "[T]his is a piece of judicial impertinence which we are not bound to respect. No such question was before the record in treating of it." 268 The "question" that Wilson referred to was of course Davis's obiter dicta statement. The Congressman went on to explain that Milligan did not present any legal point that would justify Davis in examining the powers of Congress.

The Radical Republicans immediately saw Milligan as a threat to their plans for Reconstruction. According to a correspondent from the Newark Evening Courier:

Every Republican member of Congress with whom I have conferred on the subject is out and out for abolishing the Supreme Court at once upon the ground that if Congress does not abolish it, it will abolish Congress. I find the decision of the whole court is as offensive to the Republicans of Congress as that of the majority. ${ }^{269}$

In the minds of Radical Republicans, their fears were soon realized. Once Davis's opinion was published, President Johnson immediately ordered all trials of civilians by military commissions dismissed. United States District Court Judge Hall similarly released four men convicted by a military commission in South Carolina. The Radicals were no less distressed when Dr. Samuel Mudd, one of the Lincoln assassination

\footnotetext{
${ }^{268}$ James F. Wilson, speaking on Milligan on February $22,1867,39^{\text {th }}$ Cong., $2^{\text {nd }}$ sess., Congressional Globe: 1484.

${ }^{269}$ Newark Evening Courier, January 2, 1867, quoted in Fairman, History of the Supreme Court, 222.
} 
conspirators who had been convicted by a military commission, applied for a writ of habeas corpus to Chief Justice Chase. ${ }^{270}$ Even though Chase denied the application because he could not issue a writ outside of his own Circuit, the Radicals drafted a bill on January 3, 1867 that would repeal the Habeas Corpus Act of March 3, 1863, "to prevent the Supreme Court from releasing and discharging the assassins of Mr. Lincoln and the conspirators to release the rebel prisoners [Milligan, et al.] at Camp Douglas in Chicago."271

Debate over this bill and subsequent bills regarding military reconstruction during the $39^{\text {th }}$ Congress often directly addressed Davis's opinion. Senator Reverdy Johnson defended the Court by stating, "The opinion of the majority was given by a man whose character, public and private, stands beyond possible reproach." ${ }^{272}$ In response, leading Radical Republican Thaddeus Stevens declared Milligan to be a "most injurious decision [that] has rendered immediate action by Congress upon the question of the establishment of governments in the rebel States absolutely indispensable." ${ }^{273}$ Stevens went on to reason that Davis's decision effectively took away every legal protection for loyal persons, black or white, who resided in the South. Radical Congressman John A. Bingham of Ohio suggested, "sweeping away at once the Court's appellate jurisdiction in all cases." 274 While these heated debates continued over repealing the Habeas Corpus

\footnotetext{
${ }^{270}$ Warren, The Supreme Court, 444.

271 Committee on the Judiciary, $39^{\text {th }}$ Cong., $2^{\text {nd }}$ sess., Congressional Globe: 249.

272 Reverdy Johnson speaking on Milligan on December $20,1866,39^{\text {th }}$ Cong., $2^{\text {nd }}$ sess., Congressional Globe: 210.

273 Thaddeus Stevens speaking on Milligan on January $3,1867,39^{\text {th }}$ Cong., $2^{\text {nd }}$ sess., Congressional Globe: 251.

${ }^{274}$ John A. Bingham speaking on Milligan on January $3,1867,39^{\text {th }}$ Cong., $2^{\text {nd }}$ sess., Congressional Globe: 249.
} 
Act of 1863, the New York Herald opined, "This bill, if passed into a law, will practically relieve the Supreme Court of any further interference with Congress in the business of Southern Reconstruction." ${ }^{275}$ In the end, the bill to repeal the Habeas Corpus Act of 1863 did not receive enough support, even among moderate Republicans. The Radicals, however, were not deterred in their effort to push back on a perceived threat from the Supreme Court.

The next Radical foray against the Supreme Court was reducing the number of justices on the bench through the Act of July 23, 1866. The number of justices on the Court was originally fixed at six in 1789 , had been increased to seven in 1807 , to nine in 1837, and to ten by 1863 . Having suffered through illness all of the December term, Justice Catron died in May 1865. As a result of the Act, President Johnson did not make a nomination to fill his seat before the next term. Radical Republican James F. Wilson of Iowa, chairman of the Judiciary Committee, introduced H.R. 334 on February 26, 1866 which, if adopted, would fix the number of justices on the Court at eight members. ${ }^{276}$ Congressman Wilson commented, "I know that some of the members of that court are confirmed in that opinion that the court is too large. I should be in favor myself...of still further reducing the number if another vacancy now existed."277 Wilson did not make it clear which justices shared in his view that the court was too large, but one may conjecture that Chase and his Republican colleagues feared whomever Johnson might

\footnotetext{
${ }^{275}$ New York Herald, January 23, 1867, quoted in Warren, 449.

${ }^{276}$ Fairman, History of the Supreme Court, 161

${ }^{277}$ James F. Wilson, speaking on H.R., 334, on February 26, 1866, $39^{\text {th }}$ Cong., $2^{\text {nd }}$ sess., Congressional Globe: 161.
} 
appoint. Without any debate, the House unanimously voted to send H.R. 334 to the Senate where on March $8^{\text {th }}$ the bill was placed into the hands of the Judiciary Committee for three months. ${ }^{278}$

On July $10^{\text {th }}$, Republican Senator Lyman Trumbull from Illinois reported an amendment that would reduce the Court to seven members. The amended bill was passed and sent back to the House. ${ }^{279}$ On July 18, The House agreed on the amendment and the bill was passed, 78 Republican votes to 41 Democrat votes. ${ }^{280}$ The final version read, "No vacancy in the office of associate justice of the supreme court shall be filled by appointment until the number of associate justices shall be reduced to six; and thereafter the said supreme court shall consist of a chief justice of the United States Supreme and six associate justices."281

This attack, of course, effectively prevented President Johnson from appointing any justices to the Supreme Court who would have tended to uphold his Reconstruction policy of returning political power to the Southern states. Even Justice Davis noted the Republicans' motivations behind the bill. In a letter to his brother-in-law Julius Rockwell he wrote, "But I have supposed the bill was passed simply to prevent the Presdt fr (sic) appointing Supreme Judges."282 Interestingly enough, Johnson nominated Henry Stanbery to take Justice Catron's place on April $16^{\text {th }}$. While working in the Attorney

${ }^{278}$ Committee on the Judiciary, March 8, 1866, 39 ${ }^{\text {th }}$ Cong., $2^{\text {nd }}$ sess., Congressional Globe: 1259.

${ }^{279}$ Ibid., 3699.

${ }^{280}$ Ibid., 3909.

${ }^{281}$ An Act to fix the Number of Judges of the Supreme Court of the United States, and to change certain Judicial Circuits, U.S. Statutes at Large 209 (1866).

${ }^{282}$ David Davis to Julius Rockwell, August 9, 1866, David \& Sarah Davis Family Correspondence, David Davis Mansion Historic Site, Bloomington, Illinois. 
General's office, Stanbery actually had written Johnson's March 27 veto of the Civil Rights Bill, a bill which defined U.S. citizenship and affirmed that all citizens were equally protected under the law. ${ }^{283}$ The Radicals knew how disastrous his confirmation would be to their own Reconstruction plans, and thus let the Stanbery nomination stagnate in the Senate until the Act of July 23 was passed, eliminating this possible threat. However, as Charles Fairman points out in History of the Supreme Court of the United States: Reconstruction and Reunion:

As an expedient to preclude appointments by President Johnson, the reduction of seven was unnecessary. In a Senate where the Republicans strength was well over twice that of Democrats and Johnson's friends combined, confirmation of any unsatisfactory nominee could be prevented. ${ }^{284}$

Even though reducing the number of justices on the Supreme Court was unnecessary based on the Republicans' ability to deny confirmation, it is again understandable why the Radicals took these measures. But this was not yet enough to protect freedmen in the South from all white juries and judges.

Leading Radical Republican Thaddeus Stevens commented on Milligan in January 1867, saying, "That decision although in terms not as infamous as the Dred Scott decision, is yet far more dangerous in its operation upon the lives and liberties of the loyal men of this country."285 In order to protect those lives and liberties of Unionists

\footnotetext{
${ }^{283}$ Fairman, History of the Supreme Court, 162.

${ }^{284}$ Ibid., 170.

${ }^{285}$ Nevins, "The Case of the Copperhead Conspirator," 117.
} 
and freedmen, Stevens introduced H.R. 1143 in January 1867 for the creation of "military districts...to give protection, to suppress disorder, and to cause criminals to be punishedby the local courts or, if he judged necessary, by military commission." ${ }^{286}$ Stevens introduced this bill based on his belief in the power of conquerors under the law of nations. Radical Republican Senator Zachariah Chandler of Michigan believed that the laws of war had given Lincoln the authority to appoint military governors during the war and concluded that those same laws of war gave Congress the power to reorganize the former Confederate states. ${ }^{287}$

Kentucky Democrat Lawrence S. Trimble objected to such measures. Referring to Milligan, which at this point had been decided the previous year, he prayed that the Court might "continue... as the shield and protector of the weak and the innocent through all time." 288 In his mind, the "weak and the innocent" were white southerners. Elijah Hise, also a Democrat from Kentucky, stated that the "only hope of the preservation of a free Government is in the decisions of the Supreme Court." ${ }^{289}$ Charles Eldridge of Wisconsin said that Milligan had brought "glad tidings to the depressed and despairing people. ${ }^{290}$ Frederick Pike of Maine supported the Steven's bill, insisting that Congress should set up new governments in the South. However, he "noticed that a decision [Milligan] is threatened against such action. But the court should recollect that it has had

\footnotetext{
${ }^{286}$ Ibid., 286.

${ }^{287}$ Witt, Lincoln's Code, 314.

${ }^{288}$ Lawrence S. Trimble, speaking on Milligan, on January $21,1867,39^{\text {th }}$ Cong., $2^{\text {nd }}$ sess., Congressional Globe: 66.

${ }^{289}$ Elijah Hise, speaking on Milligan, on January 21, 1867, 39th Cong., $2^{\text {nd }}$ sess., Congressional Globe: 69.

${ }^{290}$ Charles Eldridge speaking on Milligan, on January $18,1867,39^{\text {th }}$ Cong., $2^{\text {nd }}$ sess., Congressional Globe: 562.
} 
bad luck with its political decisions. The people thus far have preferred to govern the country themselves and let the court attend to its law business." ${ }^{291}$ It seems that Pike, like many of his Radical colleagues, also thought of Davis's majority opinion as a political maneuver to take away Congress's ability to set up military rule in the South. Ironically for Davis, as he saw it, he was in fact attending to "law business" rather than issuing a political decision.

On the very last day of the $39^{\text {th }}$ Congress, March 2, 1867, Steven's bill was passed over Johnson's veto. The first of four Reconstruction Acts, it divided the ten former Confederate states into five military districts and laid out the conditions for which their representatives would be re-admitted to Congress. One such condition included the ratification of the $14^{\text {th }}$ Amendment and passage of new state constitutions that incorporated the right to vote. It also laid the framework for military commissions. ${ }^{292}$ It appears then that the Radicals thought they were responding to Milligan's attempt at curtailing what they saw as their constitutionally granted authority to establish order in the former rebel states and most importantly ensure the safety and liberty of freedmen. By legislating military commissions in both the Freedman's Bureau Act and Military Reconstruction Act in response to Milligan and reducing the number of justices to prevent Johnson from appointing anyone who might be opposed to Congressional Reconstruction, the Radicals took extreme but understandable measures in order to

\footnotetext{
Globe: 255 .

${ }^{292}$ An Act to provide for the more efficient Government of the Rebel States, U.S. Statutes at Large 428 (1867).
}

${ }^{291}$ Frederick Pike, speaking on Milligan, on January $3,1867,39^{\text {th }}$ Cong., $2^{\text {nd }}$ sess., Congressional 
protect freedmen from an all-white Southern judicial system that would most assuredly be opposed toward their newly acquired rights.

One particularly prominent military commission that occurred under the First Reconstruction Act took place in November 1867, about a year after Davis released his opinion. William McCardle, the editor of the Vicksburg Times, was tried by a military commission for inciting insurrection and urging white southerners to "resist despotism and despots" and to maintain "the rights of the people who were born free." ${ }^{293}$ On November 6, he threatened to publish the names of anyone who planned to vote in the elections under the state's Reconstruction laws. Four charges were issued against him: (1) disturbance of the public peace in violation of the Act of Congress of March 2, 1867, (2) inciting insurrection, disorder, and violence, (3) libel, and (4) impeding reconstruction of the Southern states. Upon his arrest, McCardle filed for a writ of habeas corpus in the Circuit Court of the Southern District of Mississippi. Believing that the Military Reconstruction Act of March 2, which authorized cases to be brought before a military commission instead of a judge or jury, negated his authority to try McCardle, the judge remanded him back into military custody on November 25. McCardle appealed to the Supreme Court on December 23, 1867. Certiorari was granted and arguments were scheduled for the first Monday in March 1868 and spanned March $2^{\text {nd }}, 3^{\text {rd }}, 4^{\text {th }}$, and $9^{\text {th }} .94$ McCardle's appeal relied on the Habeas Corpus Act of 1867 which, ironically, granted

${ }^{293}$ Fairman, History of the Supreme Court, 416.

${ }^{294}$ Ex parte McCardle, 74 U.S. 506 (1869). 
appellate jurisdiction to the Supreme Court to review habeas corpus cases where former slaves were being held illegally. ${ }^{295}$

Fearing that the Supreme Court would declare the Reconstruction Act unconstitutional, the Radicals hurried a bill through while the Court took the case under advisement on March 9. The Act of March 27, 1868 stated, "The act approved February 5, 1867, entitled 'An act to amend an act to establish the judicial courts of the United States, approved September 24, 1789, as authorized an appeal from the judgment of the Circuit Court to the Supreme Court of the United States, or the exercise of any such jurisdiction by said Supreme Court, on appeals which have been, or may hereafter be taken, be, and the same is hereby repealed. "296 This action by the Radicals, in effect, revoked the Court's authority to review McCardle's case.

Stepping back briefly, the opening of the second session of the $40^{\text {th }}$ Congress saw significant Radical activity towards the Court. Representative John Bingham of Ohio introduced a measure on January 13, 1868 that required the vote of two-thirds of the full Court to invalidate an Act of Congress. Bingham concluded that the Court had "dared to descend from its high place in the discussion and decision of purely judicial questions to the settlement of political questions which it has no more right to decide for the American

${ }^{295}$ An Act of "An Act to amend an Act entitled 'An Act relating to Habeas Corpus, and regulating judicial Proceedings in certain Cases, "' approved May eleventh, eighteen hundred and sixty-six, U.S. Statutes at Large 385 (1867).

296 An Act Amending the Judiciary by "Giving the Right of Appeal to the Supreme Court to Persons from Erroneous Decisions of Inferior Judicial Courts, U.S. Statutes at Large 44 (1868). 
people than has the Court of St. Petersburg." 297 It is obvious that Davis's obiter dicta statement in Milligan greatly concerned the gentleman from Ohio. For him, the ability of the Supreme Court to hold a Congressional act unconstitutional was much too easy, as illustrated by Davis's statement regarding Congressional authority to establish military commissions. The bill briefly remained in the Senate but soon was forgotten due to Andrew Johnson's impeachment.

Republican Lyman Trumbull introduced S. 163 on December 4, 1867, which called for five Justices instead of six that would suffice for a quorum. ${ }^{298}$ The House Judiciary Committee adopted Bingham's measure requiring a two-thirds majority vote to have an Act of Congress declared unconstitutional. This, however, only gained the support of twenty-five Radicals. The bill was defeated 116 to 39. ${ }^{299}$ Another bill was introduced by Radical George Williams of Oregon, one that would this time curb the Supreme Court. S. 213 started out as a bill to amend the Judiciary Act by allowing the Supreme Court to review cases under the internal revenue laws. ${ }^{300}$ When it reached the House, Radical Republican James F. Wilson added an amendment that repealed the Habeas Corpus Act of $1867 .{ }^{301}$ Back in the Senate, it was passed 32 to $6 .{ }^{302}$ The bill was passed over President Johnson's veto on March 27, $1868 .^{303}$

\footnotetext{
297 John Bingham, speaking on Milligan, on January 18, 1868, 40 ${ }^{\text {th }}$ Cong., sess. 2, Congressional Globe: 483.

${ }^{298}$ Lyman Trumball, speaking on S. 163, December 4, 1867, 40 ${ }^{\text {th }}$ Cong., sess. 2, Congressional Globe: 480.

${ }^{299}$ Ibid., 489. Globe: 252

301 Ibid.,448.

${ }^{302}$ Ibid., 1847.

${ }^{303}$ Ibid., 2170.
} 
Because Chief Justice Chase concluded that Congress had complete constitutional authority to regulate the Supreme Court's jurisdiction even though the Habeas Corpus Act of 1867 lawfully allowed McCardle's appeal, Ex parte McCardle was unanimously dismissed on April 12 before an opinion could be rendered. In their minds, the Radical Republicans had gained yet another victory in a range war with the Supreme Court and successfully protected their military apparatus for the preservation of black equality before the law in the new South.

But as this thesis has contended all along, David Davis did not intend for Milligan to strike down military commissions in the Reconstruction South. Exactly what were Judge Davis' thoughts on Reconstruction in the context of Milligan? Again, documentary evidence in the form of correspondence or diaries is inconclusive. The only exception is the February $27^{\text {th }}$ letter to his brother-in-law, Julius Rockwell, in which Davis explained, "not a word is said in the opinion about reconstruction, $\&$ the power [to try by military commission] is conceded in the insurrectionary States." ${ }^{304}$ Using this letter as proof of Davis' thoughts on Reconstruction could be somewhat precarious however. Corroborating evidence for his stance on Reconstruction, therefore, may be found in Supreme Court decisions that followed Milligan.

After Congress passed the First Reconstruction Act on March 2, 1867, the state of Mississippi petitioned the Supreme Court for an injunction to prevent President Johnson from enforcing it. In Mississippi v. Johnson, the Court unanimously stated that it did not

${ }^{304}$ David Davis to Julius Rockwell, February 27, 1867, quoted in Fairman, 232-33. 
possess the authority to interfere with the President's constitutional duty of executing the laws of Congress: "Neither [Congress or the President] can be restrained in its action by the judicial departments; though the acts of both, when performed, are, in proper cases, subject to its cognizance." 305 In other words, according to the Court, it could not tell the President how to prospectively perform his executive duties, but it could review the acts stemming from his executive duties after they were performed.

The following month, the states of Georgia and Mississippi, again in an attempt to curb the Reconstruction Act, filed suit against Secretary of War Edwin Stanton for injunctive relief. As with Mississippi v. Johnson, the Supreme Court unanimously dismissed the case for want of jurisdiction to decide a political issue. The cases brought before the Court did not involve questions of persons or property but rather a political question of whether the federal government could dissolve a state government and replace it with a new one prescribed under military rule. "That these matters, both as stated in the body of the bill, and, in the prayers for relief, call for the judgment of the court upon political questions, and, upon rights, not of persons or property, but of a political character, will hardly be denied." 306 This ruling, of which Davis was a part of, is entirely consistent with the central argument of this thesis. It shows that (1) Davis upheld military commissions in the South within the Reconstruction Act, which was being challenged in this case and (2) by refusing to hear a case involving a political question, he continued to maintain a nonpartisan mindset while on the bench.

${ }^{305}$ Mississippi v. Johnson, 4 Wallace 475 (1867).

${ }^{306}$ Georgia v. Stanton, 6 Wallace 50 (1867). 
It seems obvious that Milligan's reception would fall along party lines. Democrats praised Davis's majority opinion for its defense of civil liberties during wartime. Radical Republicans on the other hand did not see it that way. For them, their most important instrument in protecting freedmen in the post-war South had just been struck down by a Supreme Court Justice that had spent the war intervening on behalf of anti-Black, Southern sympathizers. This thesis, however, has argued that Davis's wartime record of intervening on behalf of Copperheads who were being tried by the military in the North while at the same time supporting the war effort in the South, together with his February 27, 1867 letter to Julius Rockwell and the Court's unanimous rejection to review military commissions in Ex parte McCardle, Mississippi v. Johnson, and Georgia v. Stanton reveals that Davis did not intend for Milligan to apply to the South. While he himself shared many of the same racial prejudices as Copperheads, he wholly believed in the Union and equally believed that the law should be applied to those who supported the war and to those who opposed it. Most importantly, his judicial impartiality in Ex parte Milligan, despite his own racial prejudices, left military commissions in the South intact.

David Davis served on the Supreme Court until 1877. A year before, Rutherford B. Hayes, Republican Governor from Ohio ran against Samuel Tilden, the Democratic Governor of New York. Several voting irregularities occurred throughout the country during the fall election which resulted in a disputed single vote in the Electoral College. In order to remedy the brewing Constitutional crisis, Congress appointed a fifteenmember Electoral Commission to resolve the disputed vote. Davis was appointed as the 
only Independent member which would give him the deciding vote. Never in the history of the United States had one individual been given the opportunity to choose a president. On January 18,1877 , the Illinois legislature elected Davis to the United States Senate with every single Democrat vote and absolutely no Republican vote. The Democrats' ploy to gain Davis's vote backfired. Refusing to sit on the Commission and make a decision, Justice Joseph Bradley took Davis's place and gave the election to Hayes. ${ }^{307}$

On March 5, 1877, the same day Hayes was inaugurated, Davis resigned from the Supreme Court and took the oath as United States Senator. Davis's most lasting impact as a Senator was in judicial reform. He wrote a bill to create a Federal Circuit Courts of Appeal. This would effectively relieve the Supreme Court from its burdensome caseload, of which he was intimately familiar with. The bill was passed in the Senate but failed in the House. On July 2, 1881, President Garfield was mortally shot by a disgruntled officer-seeker. Two months later, the president succumbed to his wounds and died. Vice-President Chester A. Arthur assumed the Presidency, leaving the Senate president's seat vacant. Ironically, Davis who had been elected to the Senate unanimously by Democrats, was unanimously elected president pro tempore by Republicans. As the leader of the Senate he was well liked by both sides of the isles as he remained politically neutral, much like he had been on the Supreme Court. ${ }^{308}$

When his term was up, Davis did not seek reelection. In March of 1883, he retired from the Senate and returned to his home in Bloomington, Illinois. Davis's

\footnotetext{
${ }^{307}$ Bader and Williams, "David Davis," 14-15.

${ }^{308}$ Ibid., 15-16.
} 
remaining years were fairly quiet. In 1884 he was elected president of the Illinois State Bar Association and in November of 1885 delivered the eulogy for John Stuart, an old $8^{\text {th }}$ Circuit colleague of his and Lincoln. Shortly after delivering this address, Davis fell gravely ill. It was only then that doctors finally realized that the disease he had been battling for so many years was diabetes. His condition progressively worsened over the spring and on June 20 Davis slipped into a coma. He remained alive but unconscious until June 26, 1886, when he died. Four days later, six pallbearers including Robert Todd Lincoln and Adlai E. Stevenson, carried Davis's body to Evergreen Cemetery. The church bells of Bloomington rang out in honor of the jurist and statesman. ${ }^{309}$

${ }^{309}$ King, Lincoln's Manager, 306-307. 


\section{CHAPTER VI}

CONCLUSION

"The pen that writes the judgment of the Court, will be mightier

for good or for evil than any sword that ever was

wielded by mortal arm. ",310

When David Davis returned to his home in Bloomington, Illinois during the summer of 1866 to write his majority opinion in Ex parte Milligan, he was well aware of its legal significance. Milligan's historical significance was yet to be written by historians however. This study has attempted to examine the latter, specifically in regards to Civil War and Reconstruction politics. I have argued that the relevancy and historical importance of Ex parte Milligan is not in the opinion itself, but rather in its interpretation by Radical Republicans and how it was the pinnacle of Davis's maturation as a civil libertarian. The Radical Republican view that Milligan voided military commissions in the South led the Radicals in Congress to launch several attacks against the Supreme Court, thus reflecting and contributing to the existing partisanship of

${ }^{310}$ Black, "Argument of Jeremiah S. Black for the Petitioner," quoted in Klaus, The Milligan Case, 123. 
Reconstruction. Yet, as the events of Reconstruction played out, their actions were certainly justified.

David Davis's early life as a Whig instilled in him an opposition to partisan politics which he carried with him for the rest of his life. Yet he managed Lincoln's campaign in 1860 and was a fervent Whig state legislator. On the other hand, as a circuit court judge and Supreme Court justice, he was a constant guardian of the law and justice for all, regardless of party affiliation. From this perspective, we can see two different sides to Davis. He was an avid partisan politician off the bench but was a model of judicial impartiality when on the bench. As a Supreme Court justice, Davis became increasingly concerned with the growing civil liberties issues during the Civil War, specifically in the North. On several occasions Davis directly intervened on behalf of Peace Democrats who faced trial by military commissions. Among those were the defendants in the Charleston, Illinois riots and Chicago Times editor Wilber Storey. In addition, Davis personally shared his concerns with Lincoln, warning him of the dubious nature of military commissions in the North. But while adamantly opposed to Lincoln's actions in the North, he consistently upheld his actions in the South as seen in the Prize Cases. Davis's opposition to the Emancipation Proclamation can be explained by his racial prejudices but could also be used to argue that he was predisposed to strike down military commissions in the South. As we have seen, Davis chose to show judicial impartiality by setting aside his racial prejudices and leaving military courts intact as a legal safeguard for freedmen. 
With the war finally over, Ex parte Milligan offered Davis a chance to finally make a lasting statement on the legality of military commissions in the North. Davis's majority opinion was just that: a referendum on military trials of civilians in the North. Throughout the opinion, as he had during the war, Davis upheld the Lincoln administration's war effort in the rebellious states. He made a clear distinction between North and South in this manner. According to Davis's view, Indiana was not in a state of war that justified martial law and therefore did not justify the use of military commissions. This point, of course, could be an entire thesis study unto itself. Nonetheless, Davis went on to make an obiter dicta statement saying that even if Congress had authorized these military commissions in the North, they did not have Constitutional power to do so. It was therefore understandable that Radicals saw Davis's opinion as an attack on Radical Reconstruction policy, specifically in regards to using military commissions as a safeguard for freedmen's legal rights. We can also understand why it was that Radicals thought it necessary to reduce the number of justices on the Court and strip it of its jurisdictional powers to hear military commission cases.

If Milligan holds any lesson for us today, it is a political lesson rather than a legal lesson. This political lesson does not come from the Radicals though. Again, one can certainly understand why they viewed Milligan the way they did. If they thought that military commissions in the South were being struck down by the Supreme Court, their ability to protect freedmen's rights in a post-war Southern justice system would have been severely jeopardized. In other words, the lack of military commissions meant freedmen would surely have been at the mercy of all-white courts. To label the Radical's 
attacks on the Supreme Court in the aftermath of Milligan, then, is to diminish and undermine their concerns and goals of racial equality in Reconstruction South.

For purposes of this study, therefore, the lesson lies with David Davis himself. To be sure, Davis showed great judicial impartiality in his majority opinion. Considering his own racial prejudices, his opposition to emancipation and black equality, and to Radical Republicans, he very well could have extended his condemnation of military commissions into the South; yet he did not. He strongly opposed Peace Democrats as well, yet he consistently took up the cause of Peace Democrats, such as Lambdin P. Milligan, whose civil liberties, he held, were violated during the war. Davis was able to set aside the same partisan politics he had loathed his entire life and rule on his legal convictions.

It would be naïve to think that judges do not come to the bench without their own personal political persuasions and that those political persuasions do not enter into their minds as they consider the cases before them. In 2000, Bush v. Gore saw the Supreme Court vote down strictly party lines, effectively ushering in arguably one of the most economically and diplomatically devastating administrations in United States history. More recently, arguments over Justice Scalia's replacement have revolved around party politics rather than substantive judicial qualifications. As it turns out, President Obama's nominee to replace Justice Scalia understands the importance of being both a statesman and jurist. During a press conference at the White House on March 16, nominee Judge Merrick Garland stated, "The life of public service is as much a gift to the person who 
serves as it is to those he is serving." ${ }^{311}$ Long before Judge Garland made this statement, Judge Davis lived it.

In short, members of the judiciary, at all levels, should take care not to allow their political ideologies to overshadow the pursuit of justice. In a world of injustice and toxic partisanship, the judicial system can and should be a great equalizer, but we must first seek to re-instill a sense of public service, not only among those who interpret the law but those who make the law. Until then, David Davis's life and judicial career stands as an example of wisdom and statesmanship.

311 Judge Merrick Garland, "President Obama Supreme Court Nomination Announcement," http://www.c-span.org/video/?406805-1/president-obama-supreme-court-nomination-announcement. 


\section{REFERENCES}

\section{PRIMARY SOURCES}

Government Documents and Statutes

An Act amendatory of "An Act to amend an Act entitled 'An Act relating to Habeas

Corpus, and regulating judicial Proceedings in certain Cases, '" approved May

eleventh, eighteen hundred and sixty-six. U.S. Statues at Large 385 (1867).

An Act Amending the Judiciary by "Giving the Right of Appeal to the Supreme Court to Persons from Erroneous Decisions of Inferior Judicial Courts. U.S. Statutes at Large 44 (1868).

An Act for Establishing Rules and Articles for the Government of the Armies of the United States. U.S. Statues at Large 371 (1806).

An Act relating to Habeas Corpus, and regulating Judicial Proceedings in Certain Cases. U.S. Statutes at Large 755 (1863).

An Act to amend an act entitled "An act to establish a Bureau for the relief of Freedmen and Refugees," and for other purposes. U.S. Statutes at Large 173 (1866).

An Act to amend the Judicial System of the United States. U.S. Statutes at Large 156 (1802).

An Act to fix the Number of Judges of the Supreme Court of the United States, and to change certain Judicial Circuits. U.S. Statutes at Large 209 (1866).

An Act to provide for the more efficient Government of the Rebel States. U.S. Statutes at Large 428 (1867).

An Act to recognize and adapt to the Constitution of the United States, the establishment of the troops raised under the resolves of the United States, in Congress assembled. U.S. Statutes at Large 96 (1789).

Black, Jeramiah S. "Argument of Jeremiah S. Black for the Petitioner.” 1866. In Samuel The Milligan Case, edited by Samuel Klaus, New York: Knopf, 1929. 
Bush, George W. Military Order. "Detention, Treatment, and Trial of Certain NonCitizens in the War Against Terrorism." Federal Register 68, no. 57 (November 16, 2001): 833 .

Butler, Benjamin F. "Reply of Benjamin F. Butler for the United States." Quoted in Samuel Klaus, ed. The Milligan Case. New York: Knopf, 1929.

Field, David Dudley. "Argument of David Dudley Field for the Petitioner." Quoted in Samuel Klaus, ed. The Milligan Case. New York: Knopf, 1929.

Garfield, James Abram. "Argument of James Abram Garfield for the Petitioner." Quoted in Samuel Klaus ed. The Milligan Case. New York: Knopf, 1929.

Letters Received by the Office of the Adjutant General. Washington: National Archives and Records Administration, 1861-1870.

Lincoln, Abraham. Military Order. "General Orders No. 104.” (August 13, 1862). Quoted in Mark Neely, Jr. The Fate of Liberty: Abraham Lincoln and Civil Liberties. New York: Oxford University Press, 1991.

Lincoln, Abraham. Military Order. "Order to General Scott." 1861. In Abraham Lincoln: Complete Works, Comprising His Speeches, Letters, State Papers, and Miscellaneous Writings, edited by John G. Nicolay and John Hay. New York: The Century Co., 1894.

"Military Commission Transcript." Quoted in Samuel Klaus, ed. The Milligan Case. New York: Knopf, 1929.

Speed, James. "Argument of James Speed for the United States.” Quoted in Samuel Klaus, ed. The Milligan Case. New York: Knofp, 1929.

Stanbery, Henry. "Argument in the Supreme Court of the United States on the Side of the United States." Quoted in Samuel Klaus, ed. The Milligan Case. New York: Knopf, 1929.

U.S. Congress. Congressional Globe. $39^{\text {th }}$ Cong., $1^{\text {st }}$ sess.

U.S. Congress. Congressional Globe. $39^{\text {th }}$ Cong., $2^{\text {nd }}$ sess.

U.S. Congress. Congressional Globe. $40^{\text {th }}$ Cong., $2^{\text {nd }}$ sess. 


\section{$\underline{\text { Personal Papers }}$}

Browning, Orville Hickman. The Diary of Orville Hickman Browning. Edited by Theodore Pease and J.G. Randall. Springfield: Illinois State Historical Library, 1925.

David \& Sarah Davis Family Correspondence. David Davis Mansion Historic Site, Bloomington, Illinois.

Lincoln Abraham. Abraham Lincoln: Complete Works, Comprising His Speeches, Letters, State Papers, and Miscellaneous Writings. Edited by John G. Nicolay and John Hay. New York: The Century Co., 1894.

Lincoln, Abraham. Collected Works of Abraham Lincoln. Volume V. Edited by Roy Basles. New Brunswick, N.J.: Rutgers University Press, 1953.

Lincoln, Abraham. "Corning Letter." In Lincoln and the Triumph of the Nation: Constitutional Conflict in the American Civil War, Mark Neely, Jr. Chapel Hill: University of North Carolina Press, 2011.

Lincoln, Abraham. The Abraham Lincoln Papers at the Library of Congress. https://memory.loc.gov/ammem/alhtml/malhome.html.

\section{$\underline{\text { Public Addresses }}$}

Garland, Judge Merrick. "President Obama Supreme Court Nomination Announcement." http://www.c-span.org/video/?406805-1/president-obama-supreme-courtnomination-announcement.

Lincoln, Abraham. "Speech on the Dred Scott Decision." Springfield: IL, June 26, 1857 in Maureen Harrison, ed. Abraham Lincoln: Word for Word. San Diego: Excellent Books, 1994.

Books and Pamphlets

Binney, Horace. The Privilege of the Writ of Habeas Corpus under the Constitution. Philiadelphia: Sherman \& Sons, 1862.

Craighill, William P. The Army Officers Pocket Companion for Staff Officers in the Field. New York: D. Van Nostrand, 1862.

Klaus, Samuel ed. The Milligan Case. New York: Knopf, 1929.

Lieber, Francis. Instructions for the Government of Armies of the United States in the Field. New York: D. Van Nostrand, 1863. 
The 1863 Laws of War. Washington: War Department, 1863.

The American Law Review. (April 1867, I, 572). In The Supreme Court in United States History, Charles Warren. Vol. II. Boston: Little, Brown, and Company, 1935.

Newspapers

Arkansas Gazette. December 19, 1866. Quoted in Charles Fairman. History of the Supreme Court of the United States. New York: The Macmillan Co., 1971.

Chicago Times. March 17, 1863. Quoted in Craig D. Tenney. "To Suppress or Not to

Suppress: Abraham Lincoln and the Chicago Times." Civil War History 27, no. 3 (September 1981): 248-259.

Chicago Tribune. January 4, 1867. Quoted in Charles Fairman. History of the Supreme Court of the United States. New York: The Macmillan Co., 1971.

Indianapolis Journal. May 8, 1863. Quoted in Willard L. King. Lincoln's Manager: David Davis. Cambridge: Harvard University Press, 1960.

Louisville Democrat. January 5, 1867. Quoted in Charles Fairman. History of the Supreme Court of the United States. New York: The Macmillan Co., 1971.

Newark Evening Courier. January 2, 1867. Quoted in Charles Fairman. History of the Supreme Court of the United States. New York: The Macmillan Co., 1971.

New York Herald. January 2, 1867. Quoted in Charles Warren, The Supreme Court in United States History. vol. II. Boston: Little, Brown, and Company, 1935.

New York Herald. January 23, 1867. Quoted in Charles Warren. The Supreme Court in United States History. vol. II. Boston: Little, Brown, and Company, 1935.

New York Times. January 3, 1867. Quoted in Charles Warren. The Supreme Court in United States History. vol. II. Boston: Little, Brown, and Company, 1935.

New York World. January 12, 1867. Quoted in Charles Warren. The Supreme Court in United States History. vol. II. Boston: Little, Brown, and Company, 1935.

Pantagraph. January 8, 1867. Quoted in Charles Fairman. History of the Supreme Court of the United States. New York: The Macmillan Co., 1971. 
Picayune. January 8, 1867. Quoted in Charles Fairman. History of the Supreme Court of the United States. New York: The Macmillan Co., 1971.

Springfield Republican. January 2, 1867. Quoted in Charles Fairman. History of the Supreme Court of the United States. New York: The Macmillan Co., 1971.

The Enquirer. December 19, 1866. Quoted in Charles Fairman. History of the Supreme Court of the United States. New York: The Macmillan Co., 1971.

The Nation. 3:510 (December 27, 1866). Quoted in Charles Fairman. History of the Supreme Court of the United States. New York: The Macmillan Co., 1971.

“The New Dred Scott.” Harper's Weekly. January 19, 1867. Quoted in Robert Fridlington. The Reconstruction Court. New York: Associated Faculty Press, 1987.

Legal Cases

Barron v. Baltimore. 32 U.S. (7 Pet.) 243 (1833).

Boumediene v. Bush. 553 U.S. 723 (2008).

Dred Scott v. John F. A. Sandford. 60 U.S. 393 (1857).

Duncan v. Kahanamoku. 327 U.S. 304 (1946).

Ex parte McCardle. 74 U.S. 506 (1869).

Ex parte Merryman. 17 Fed. 144, 147 (No. 9,487) (D.C. Md. 1861).

Ex parte Milligan. 71 U.S. 2, 6 (1866).

Ex parte Quirin. 317 U.S. 1 (1945).

Ex parte Vallandigham. 68 U.S. 1 Wall. 243253 (1863).

Fletcher v. Peck. 10 U.S. 87 (1810).

Georgia v. Stanton. 6 Wallace 50 (1867).

Hamdi v. Rumsfield. 542 U.S. 507 (2004).

Jecker v. Montgomery. 13 How. (54 U.S.) 498, 515 (1852). 
Mississippi v. Johnson. 4 Wallace 475 (1867).

Padilla v. Hanft. 423 F.3d $3864^{\text {th }}$ Cir. (2005).

People v. Hill. (June 12, 1854).

Rasul v. Bush. 542 U.S. 466 (2004).

The Brig Amy Warwick, The Schooner Crenshaw, The Barque Hiawatha, and The Schooner Brilliante. 67 U.S. 635 (1863).

\section{SECONDARY SOURCES}

$\underline{\text { Books }}$

Benedict, Michael Les. A Compromise of Principle: Congressional Republicans and Reconstruction, 1863-1869. New York: Norton \& Company, 1974.

Bishop, Joseph W. Justice Under Fire: A Study of Military Law. New York: Charterhouse, 1974.

Blair, William C. With Malice Toward Some: Treason and Loyalty in the Civil War Era. Chapel Hill: The University of North Carolina Press, 2014.

Brandwein, Pamela. Rethinking the Judicial Settlement of Reconstruction. New York: Cambridge University Press, 2011.

Brown, Thomas J., ed. Reconstructions: New Perspectives on the Postbellum United States. New York: Oxford University Press, 2006.

Burgess, John W. Political Science and Comparative Constitutional Law. Boston: Ginn \& Company, 1891. Quoted in Peter J. Barry. "Ex parte Milligan: History and Historians.” Indiana Magazine of History 4 (December 2013): 355-379.

Chafee, Zechariah, Jr. Freedom of Speech. New York: Harcourt, Brace and Howe, 1920. Quoted in Peter J. Barry. "Ex parte Milligan: History and Historians." Indiana Magazine of History 4 (December 2013): 355-379.

Churchill, Robert H. To Shake Their Guns in the Tyrant's Face: Libertarian Political Violence and the Origin of the Militia Movement. Ann Arbor: The University of Michigan Press, 2009. 
Cole, Arthur C. Constitutional Debates of 1847. Springfield: Illinois State Historical Library, 1919.

Du Bois, W.E.B. Black Reconstruction in America. New York: Russell \& Russell, 1962.

Fairman, Charles. History of the Supreme Court of the United States. New York: The Macmillan Co., 1971.

Farber, Daniel. Lincoln's Constitution. Chicago: University of Chicago Press, 2003.

Fisher, Louis. Military Tribunals \& Presidential Power: American Revolution to the War on Terrorism. Lawrence, Kansas: The University Press of Kansas, 2005.

Foner, Eric. Reconstruction: America's Unfinished Revolution 1863-1877. New York: Harper \& Row, 1988.

Fridlington, Robert. The Reconstruction Court. New York: Associated Faculty Press, 1987.

Friedman, Lawrence M. A History of American Law. New York: Simon \& Schuster, 1973.

Friedman, Leon and Louis H. Israel, eds. The Justices of the United States Supreme Court. New York: R.R. Bowker, 1969.

Garraty, John A., ed. Quarrels That Have Shaped the Constitution. New York: Harper, 1964.

Gillette, William. Retreat From Reconstruction: 1869-1879. Baton Rouge: Louisiana State University, 1979.

Hall, Kermit L. The Magic Mirror: Law in American History. New York: Oxford University Press, 1989.

Herndon, William and Jesse W. Weik. Herndon's Lincoln. Urbana: University of Illinois Press, 2006.

Holt, Michael. The Rise and Fall of the American Whig Party: Jacksonian Politics and the Onset of the Civil War. New York: Oxford University Press, 1999.

Horwitz, Morton. Transformation of American Law. New York: Oxford University Press, 1977. 
Hyman, Harold. A More Perfect Union: The Impact of the Civil War and Reconstruction on the Constitution. New York: Alfred A. Knopf, 1973.

Hyman, Harold and William M. Weicek. Equal Justice Under the Law: Constitutional Development, 1835-1875. New York: Harper \& Row, 1982.

King, Willard L. Lincoln's Manager: David Davis. Cambridge: Harvard University Press, 1960.

Klement, Frank L. Copperheads in the Middle West. Chicago: University of Chicago Press, 1960.

Klement, Frank L. Dark Lanterns: Secret Political Societies, Conspiracies, and Treason Trials in the Civil War. Baton Rouge: Louisiana Press University, 1989.

Kutler, Stanley. Judicial Power and Reconstruction Politics (Chicago: University of Chicago Press, 1968). Quoted in Peter J. Barry. "Ex parte Milligan: History and Historians." Indiana Magazine of History 4 (December 2013):355-379.

Les Benedict, Michael. A Compromise of Principle: Congressional Republicans and Reconstruction, 1863-1869. New York: Norton \& Company, 1974.

Les Benedict, Michael. Preserving the Constitution: Essays on Politics and the Constitution in the Reconstruction Era. New York: Fordham University Press, 2006.

McGinty, Brian. Lincoln \& The Court. Cambridge: Harvard University Press, 2008.

Miller, William Lee. Lincoln's Virtues: An Ethical Biography. New York: Alfred A. Knopf, 2002.

Moore, William F. and Jane Anne Moore. Collaborators for Emancipation: Abraham Lincoln and Own Lovejoy. Urbana: University of Illinois Press, 2014.

Neely, Mark Jr. Lincoln and the Triumph of the Nation: Constitutional Conflict in the American Civil War. Chapel Hill: University of North Carolina Press, 2011.

Neely, Mark Jr. The Fate of Liberty: Abraham Lincoln and Civil Liberties. New York: Oxford University Press, 1991.

Novak, William J. The People's Welfare: Law and Regulation in Nineteenth-Century America. Chapel Hill: University of North Carolina Press, 1996. 
Randall, James G. Constitutional Problems under Lincoln. New York: D. Appleton and Company, 1926. Quoted in Peter J. Barry. "Ex parte Milligan: History and Historians." Indiana Magazine of History 4 (December 2013): 355-379.

Rehnquist, William H. All the Laws But One: Civil Liberties in Wartime. New York: Alfred Knopf, 1988.

Schlesigner, Arthur M. The Age of Jackson. Boston: Little, Brown and Company, 1953.

Schroeder, Christopher and Curtis A. Bradley, eds. Presidential Power Stories. St. Paul: Foundation Press, 2009.

Schweber, Howard. The Creation of American Common Law, 1850-1880. Cambridge: Cambridge University Press, 2004.

Sprague, Dean. Freedom Under Lincoln. Boston: Houghton Mifflin, 1965.

Towne, Stephen E. Surveillance and Spies in the Civil War: Exposing Confederate Conspiracies in America's Heartland. Athens: Ohio University Press, 2015.

Warren, Charles. The Supreme Court in United States History. vol. II. Boston: Little, Brown, and Company, 1935.

Weber, Jennifer. Copperheads: The Rise and Fall of Lincoln's Opponents in the North. Oxford: Oxford University Press, 2006.

Weik, Jesse. The Real Lincoln: A Portrait. Boston: Houghton Mifflin, 1923.

White, Ronald C. A. Lincoln: A Biography. New York: Random House, 2009.

Witt, John Fabian. Lincoln's Code: The Laws of War in American History. New York: Free Press, 2012.

\section{Articles}

Bader, William D. and Frank J. Williams. "David Davis: Lawyer, Judge, and Politician in the Age of Lincoln." Roger Williams University Law Review 14 (Spring, 2009): 163-214.

Barnett, Randy E. "From Antislavery Lawyer to Chief Justice: The Remarkable but Forgotten Career of Salmon P. Chase." Georgetown University Law Center 63 Case W. Res. L. Rev. (2013): 653-702. 
Barry, Peter J. "Ex parte Milligan: History and Historians." Indiana Magazine of History 4 (December 2013): 355-379.

Barry, Peter J. "'I'll keep them in prison awhile...': Abraham Lincoln and David Davis on Civil Liberties in Wartime." Journal of the Abraham Lincoln Association 28, no. 1 (Winter 2007): 20-29.

Benedict, Michael Les. "Constitutional Politics, Constitutional Law, and the Thirteenth Amendment." Maryland Law Review. 71 no.1 (2011): 163-188.

Bradley, Curtis A. "The Story of Ex parte Milligan: Military Trials, Enemy Combatants, and Congressional Authorization." In Presidential Power Stories, edited by Christopher H. Schroeder and Curtis A. Bradley, 93-132. St. Paul: Foundation Press, 2009.

Curry, Richard O. "Copperheadism and Continuity: the Anatomy of a Stereotype." Journal of Negro History 57, no. 1 (January 1972): 29-36.

Dueholm, James A. "Lincoln's Suspension of the Writ of Habeas Corpus: An Historical \& Constitutional Analysis." Journal of the Abraham Lincoln Association 29, no. 2 (Summer 2008): 47-66.

Dunning, William A. "The Constitution of the United States in Reconstruction." Political Science Quarterly 2 (December 1887): 558-602. Quoted in Peter J. Barry. "Ex parte Milligan: History and Historians." Indiana Magazine of History 4 (December 2013): 355-379.

Fairman, Charles. "The Law of Martial Rule and the National Emergency." Harvard Law Review 55 (June 1942): 1253-1302. Quoted in Peter J. Barry. "Ex parte Milligan: History and Historians." Indiana Magazine of History 4 (December 2013): 355379.

Fisher, Louis. "Military Tribunals: Historical Patterns and Lessons." Congressional Research Service Report for Congress. Washington D.C.: The Library of Congress (July 9, 2004): 1-45.

Fisher, Sydney G. "The Suspension of Habeas Corpus During the War of the Rebellion." Political Science Quarterly 3 (September 1888): 454-488. Quoted in Peter J. Barry. "Ex parte Milligan: History and Historians." Indiana Magazine of History 4 (December 2013): 355-379.

Fitzgerald, Michael W. "Reconstruction Politics and the Politics of Reconstruction." In Reconstructions: New Perspectives on the Postbellum United States, edited by Thomas J. Brown, 91-116. New York: Oxford University Press, 2006. 
Fletcher, Henry J. "The Civilian and the War Power." Minnesota Law Review 2 (1917): 730-755. Quoted in Peter J. Barry. "Ex parte Milligan: History and Historians." Indiana Magazine of History 4 (December 2013): 355-379.

Foner, Eric. "Dare Call It Treason." The Nation (June 2, 2003): 13. Quoted in Peter J. Barry. "Ex parte Milligan: History and Historians." Indiana Magazine of History 4 (December 2013): 355-379.

Frank, John P. "Ex Parte Milligan v. The Five Companies: Martial Law in Hawaii." Columbia Law Review 44 (September 1944): 639-688. Quoted in Peter J. Barry. "Ex parte Milligan: History and Historians." Indiana Magazine of History 4 (December 2013): 355-379.

Friedman, Leon. "Salmon P. Chase.” In The Justices of the United States Supreme Court, edited by Leon Friedman and Louis H. Israel, 1113-1149. New York: R.R. Bowker, 1969.

Gambone, Joseph G. "Ex Parte Milligan: The Restoration of Judicial Prestige?" Civil War History 16 (September, 1970): 246-259. Quoted in Peter J. Barry. "Ex parte Milligan: History and Historians." Indiana Magazine of History 4 (December 2013): 355-379.

Meites, Jerome B. "The 1847 Illinois Constitutional Convention and Persons of Color." Journal of the Illinois State Historical Society 108, no. 3 (Fall 2015): 266-295.

Nevins, Allan. "The Case of the Copperhead Conspirator." In Quarrels That Have Shaped the Constitution, edited by John A Garraty, 101-118. New York: Harper, 1964, 108.

Oakes, James. 'Natural Rights, Citizenship Rights, States' Rights, and Black Rights: Another Look at Lincoln.” In Our Lincoln, edited by Eric Foner, 109-134. New York: W.W. Norton: November, 2008):

Petlack, Karin. "A Dilemma of Civil Liberties: Blacks under Union Military Control, 1861-1866.” PhD diss., University of California, Berkley, 2013.

Pratt, Harry E. "David Davis.” PhD diss., University of Illinois, 1930.

Rockenbach, Stephen I. "A Border City at War: Louisville \& the 1862 Invasion of Kentucky.” Ohio Valley History. 3, no. 4 (Winter 2003): 35-52.

Stephens, Gail. "This City Must Not Be Taken." Traces of Indiana \& Midwestern History. 22, no. 2 (Spring 2010): 4-17. 
Tenney, Craig D. "To Suppress or Not to Suppress: Abraham Lincoln and the Chicago Times." Civil War History. 27, no. 3 (September 1981): 248-259.

Towne, Stephen E. "Killing the Serpent Speedily: Governor Morton, General Hascall, and the Suppression of the Democratic Press in Indiana, 1863." Civil War History 52, no. 1 (March 2006): 41-65.

Towne, Stephen E. "The Persistent Nullifier: The Life of Civil War Conspirator Lambdin P. Milligan.” Indiana Magazine of History 109 (December 2013): 303-354.

Towne, Stephen E. "Worse than Vallandigam: Governor Oliver P. Morton, Lambdin P. Milligan, and the Military Arrest and Trial of Indiana State Senator Alexander J. Douglas During the Civil War.” Indiana Magazine of History 106 (March 2010): $1-39$.

Vagts, Detlev F. "Military Commissions: The Forgotten Reconstruction Chapter." American University International Law Review 23, no. 2 (2007): 231-274.

Yoo, John. “Merryman and Milligan.” Journal of Supreme Court History 34 (November 2008): 505-534. 